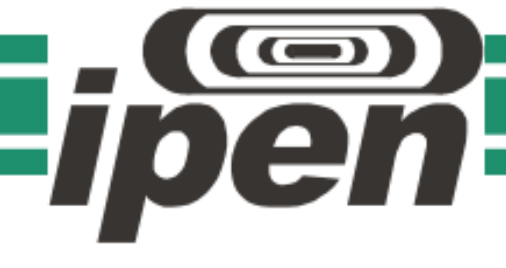

AUTARQUIA ASSOCIADA A UNIVERSIDADE DE SÃO PAULO

ANÁLISE DO COMPORTAMENTO SOB IRRADIAÇÃO DO COMBUSTÍVEL NUCLEAR A ALTAS QUEIMAS COM OS PROGRAMAS COMPUTACIONAIS FRAPCON E FRAPTRAN

Regis Reis

Dissertação apresentada como parte dos requisitos para obtenção do Grau de Mestre em Ciências na Área de Tecnologia Nuclear - Reatores

Orientador:

Prof. Dr. Antonio Teixeira e Silva 


\section{ipen}

INSTITUTO DE PESQUISAS ENERGÉTICAS E NUCLEARES

Autarquia Associada à Universidade de São Paulo

ANÁLISE DO COMPORTAMENTO SOB IRRADIAÇÃO DO COMBUSTÍVEL NUCLEAR A ALTAS QUEIMAS COM OS PROGRAMAS COMPUTACIONAIS FRAPCON E FRAPTRAN

Regis Reis

Dissertação apresentada a como parte dos requisitos para a obtenção do Grau de Mestre em Ciências na Área de Tecnologia Nuclear - Reatores

Orientador:

Prof. Dr. Antonio Teixeira e Silva

Versão Corrigida

Versão Original disponível no IPEN

São Paulo

2014 
Dedico este trabalho aos meus pais Dirceu e Alzira, às minhas irmãs Suely e Patrícia e ao meu irmão Reinaldo pelo apoio que recebi. 


\section{AGRADECIMENTOS}

Ao Instituto de Pesquisas Energéticas e Nucleares (IPEN/CNEN-SP) pelo fornecimento de salas e equipamentos utilizados e aos professores da Comissão de Pósgraduação que foram essenciais para meu aprendizado.

Ao Prof. Dr. Antonio Teixeira e Silva pela sua orientação, ensinamentos, paciência e dedicação, que foram fundamentais para a conclusão do presente trabalho.

Aos amigos da Universidade Metodista, Carlos Eduardo Santi, Mario Boaratti, Claudio Torres e demais colegas pelos conselhos, lições e, principalmente, pelo apoio e encorajamento.

E em especial aos meus pais e familiares que sempre me apoiaram durante todos esses anos. 
Só é útil o conhecimento que nos torna melhores. (Socrates). 


\title{
ANÁLISE DO COMPORTAMENTO SOB IRRADIAÇÃO DO COMBUSTÍVEL NUCLEAR A ALTAS QUEIMAS COM OS PROGRAMAS COMPUTACIONAIS FRAPCON E FRAPTRAN
}

\author{
Regis Reis
}

\section{RESUMO}

O objetivo deste trabalho é verificar a validade e a acurácia dos resultados fornecidos pelos programas computacionais FRAPCON-3.4a e FRAPTRAN-1.4, utilizados no processo de simulação do comportamento de varetas combustíveis de reatores a água leve pressurizada - PWR (Pressurized Water Reactor), sob situações operacionais de regimes permanente e transiente, em condições de alta queima (high burnup).

Para realizar a verificação, foi utilizada a base de dados FUMEX-III, que fornece dados relativos a experimentos realizados com diversos tipos de combustíveis nucleares, submetidos a diversas condições operacionais.

Através dos resultados obtidos nas simulações computacionais com os programas FRAPCON-3.4a e FRAPTRAN-1.4 e da sua comparação com os dados experimentais da base FUMEX-III, foi possível constatar que os programas empregados possuem um boa capacidade de predizer o comportamento operacional de varetas combustíveis de PWR em regime permanente a altas queimas e sob condição de transiente inicializado por reatividade (Reactivity Initiated Accident - RIA). 


\title{
ANALYSIS OF THE BEHAVIOR UNDER IRRADIATION OF HIGH BURNUP \\ NUCLEAR FUELS WITH THE COMPUTER PROGRAMS FRAPCON AND FRAPTRAN
}

\author{
Regis Reis
}

\begin{abstract}
The objective of this work is to verify the validity and accuracy of the results provided by the computer programs FRAPCON-3.4a and FRAPTRAN-1.4, used in the simulation process of the irradiation behavior of Pressurized Water Reactors (PWR) fuel rods in steady-state and transient operational conditions at high burnup.

To perform the verification, the database FUMEX-III was used to provide data on experiments with different nuclear fuel types, under various operating conditions.

Through the comparison of the computational simulation results of the programs FRAPCON-3.4a e FRAPTRAN-1.4 with the experimental data of the database FUMEX III, it was found that the computer programs used have good ability to predict the operational behavior of PWR fuel rods in high burnup steady-state conditions and under Reactivity Initiated Accident (RIA).
\end{abstract}




\section{LISTA DE FIGURAS}

FIGURA 2.1 Elemento combustível típico de um reator PWR (Pressurized Water

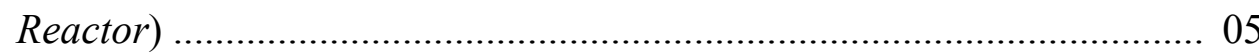

FIGURA 2.2 Vareta combustível tipicamente utilizada em reatores PWR ................. 06

FIGURA 2.3 Alterações observadas em uma pastilha de $\mathrm{UO}_{2}$ durante a irradiação devido aos elevados gradientes de temperaturas e à radiação ................. 08

FIGURA 2.4 Mecanismo de densificação devido à irradiação ...................................... 09

FIGURA 2.5 Trincamento e relocação de uma pastilha combustível ........................... 10

FIGURA 2.6 Seção transversal de uma pastilha combustível de $\mathrm{UO}_{2}$ irradiada revelando a formação de poros na região central do combustível ........... 12

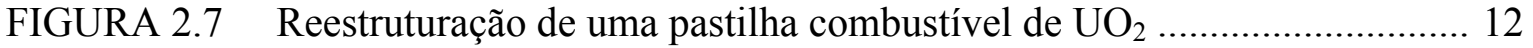

FIGURA 2.8 Representação esquemática das alterações microestruturais em uma pastilha combustível de $\mathrm{UO}_{2}$ altamente irradiada .......................... 13

FIGURA 2.9 Seção transversal de uma vareta combustível com falha ocasionada por PCI .................................................................. 16

FIGURA 2.10 Efeito da irradiação por nêutrons nas propriedades de Tração do Zircaloy 19

FIGURA 2.11 Efeito da irradiação no comportamento da fluência do Zircaloy submetido a $300{ }^{\circ} \mathrm{C}$

FIGURA 2.12 Variação da espessura da zona de reestruturação (rim zone) para uma pastilha de $\mathrm{UO}_{2}$. Dados obtidos através de cálculos e por meio de microscopia eletrônica

FIGURA 2.13 Micrografia óptica mostrando a região periférica de uma pastilha combustível de reator PWR com diferentes queimas. A formação e o crescimento da zona de reestruturação (rim zone) é claramente visível

FIGURA 2.14 Liberação atérmica de gás de fissão (FGR) em função da queima 25

FIGURA 2.15 Comparação entre os modelos de (KINOSHITA et al., 2004) e (OHIRA e ITAGAKI, 1997)/FRAPCON para a determinação da condutividade térmica do $\mathrm{UO}_{2}$ 
FIGURA 2.16 Influência da presença da estrutura de alta queima (HBS) na difusividade térmica do $\mathrm{UO}_{2}$

FIGURA 2.17 Espessura da camada de óxido no revestimento de Zircaloy-4 em função da queima

FIGURA 3.1 Inter-relação entre os diversos modelos utilizados em um código de análise de desempenho de varetas combustíveis utilizadas em reatores LWR 33

FIGURA 4.1 Estrutura modular simplificada do programa computacional FRAPCON-3.4a 38

FIGURA 4.2 Fluxograma simplificado do programa computacional FRAPCON-3 .... 39

FIGURA 4.3 Fluxograma do laço de convergência para a obtenção da queda de temperatura na interface combustível revestimento 41

FIGURA 4.4 Fluxograma do código FRAPCON-3 42

FIGURA 4.5 Fluxograma indicando a sequência de execução dos modelos presentes no código FRAPTRAN-1.4 45

FIGURA 4.6 Fluxograma detalhado do código FRAPTRAN-1.4 47

FIGURA 5.1 Variação da temperatura da região central da vareta combustível em função da queima fornecida pelo relatório FUMEX III

FIGURA 5.2 Variação da temperatura da região central da vareta combustível em função da queima fornecida pelo código FRAPCON-3.4a 52

FIGURA 5.3 Valor experimental e predições dos códigos computacionais para a liberação de gás de físsão 53

FIGURA 5.4 Valor experimental e predição do código FRAPCON-3.4a para a liberação de gás de fissão 53

FIGURA 5.5 Valor experimental e predições dos códigos computacionais para a volume livre no interior da vareta combustível 55

FIGURA 5.6 Valor experimental e predição do código FRAPCON-3.4a para a determinação do volume livre da vareta combustível 55

FIGURA 5.7 Predições dos códigos computacionais para pressão interna da vareta combustível 56

FIGURA 5.8 Variação da pressão interna da vareta combustível em função da queima fornecida pelo código FRAPCON-3.4a 56

FIGURA 5.9 Variação da temperatura da região central da vareta combustível em função da queima 60 
FIGURA 5.10 Variação da temperatura da região central da vareta combustível durante a rampa de potência aplicada no final da vida da vareta combustível

FIGURA 5.11 Variação da temperatura da região central da vareta combustível em função da queima obtida pelo código FRAPCON-3.4a 61

FIGURA 5.12 Variação da temperatura da região central da vareta combustível durante a rampa de potência aplicada no final da vida da vareta combustível obtida pelo código FRAPCON-3.4a 61

FIGURA 5.13 Valor experimental e predições dos códigos computacionais para a liberação de gás de fissão

FIGURA 5.14 Valor experimental e predição do código FRAPCON-3.4a para a liberação de gás de fissão 63

FIGURA 5.15 Processo de simulação utilizando-se os códigos FRAPCON-3.4a e FRAPTRAN-1.4 66

FIGURA 5.16 Temperatura na região central da pastilha combustível durante a aplicação do pulso para simulação de RIA 68

FIGURA 5.17 Variação da temperatura da região central da vareta combustível em função do tempo decorrido do pulso fornecida pelo código FRATRAN-1.4 68

FIGURA 5.18 Predições dos códigos computacionais para a pressão interna da vareta combustível FK-1 em função do tempo decorrido da aplicação do pulso para simulação de RIA

FIGURA 5.19 Variação da pressão interna da vareta combustível FK-1 em função do tempo decorrido do pulso para simulação de RIA fornecida pelo código FRAPTRAN-1.4

FIGURA 5.20 Predições dos códigos computacionais para o alongamento da coluna de pastilhas combustíveis da vareta FK-1 em função do tempo decorrido da aplicação do pulso para simulação de RIA 71

FIGURA 5.21 Alongamento da coluna de pastilhas combustíveis da vareta combustível FK-1 em função do tempo decorrido do pulso para simulação de RIA fornecida pelo código FRAPTRAN-1.4 
FIGURA 5.22 Predições dos códigos computacionais para o alongamento do revestimento da vareta FK-1 em função do tempo decorrido da aplicação do pulso para simulação de RIA

FIGURA 5.23 Alongamento do revestimento da vareta combustível FK-1 em função do tempo decorrido do pulso para simulação de RIA fornecida pelo código FRAPTRAN-1.4 


\section{LISTA DE TABELAS}

TABELA 3.1 Relação dos casos disponibilizados ao final do programa FUMEX III

TABELA 5.1 Características da vareta combustível TSQ002 no início e no final de vida 49

TABELA 5.2 Características da vareta combustível ZX115 utilizada no experimento RISOEIII-GE7

TABELA 5.3 Características de projeto e condições de pré-pulso para RIA da Vareta combustível utilizada no teste FK-1 64

TABELA 5.4 Condições de teste e resumo dos resultados após pulso para RIA da vareta combustível utilizada no teste FK-1 


\section{LISTA DE ABREVIATURAS E SIGLAS}

\begin{tabular}{|c|c|}
\hline $\mathrm{BOL}$ & Begin Of Life \\
\hline BWR & Boiling Water Reactor \\
\hline EOL & End Of Life \\
\hline FGR & Fission Gas Release \\
\hline FRAPCON & Steady State Fuel Rod Performance Code \\
\hline FRAPTRAN & Fuel Rod Analysis Program Transient \\
\hline FUMEX & Fuel Modelling at Extended Burnup \\
\hline HBS & High Burnup Structure \\
\hline INEEL & Idaho National Engineering and Environmental Laboratory \\
\hline IFBA & Integral Fuel Burnable Absorber \\
\hline LOCA & Loss of Coolant Accident \\
\hline LWR & Light Water Reactor \\
\hline MOX & Mixed Oxide Fuel \\
\hline NSRR & Nuclear Safety Research Reactor \\
\hline PCCI & Pellet Clad Chemical Interaction \\
\hline PCI & Pallet Clad Interaction \\
\hline PCMI & Pallet Clad Mechanical Interaction \\
\hline PNNL & Pacific Northwest National Laboratory \\
\hline PWR & Pressurized Water Reactor \\
\hline RIA & Reactivity Initiated Accident \\
\hline SCC & Stress Corrosion Cracking \\
\hline U.S.NRC & United States Nuclear Regulatory Commission \\
\hline
\end{tabular}




\section{SUMÁRIO}

LISTA DE FIGURAS

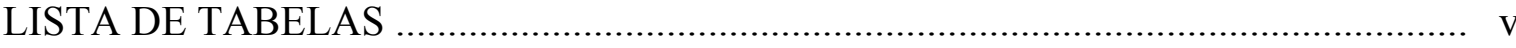

LISTA DE ABREVIATURAS E SIGLAS …......................................................... vi

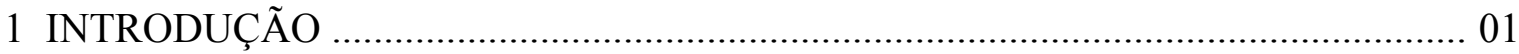

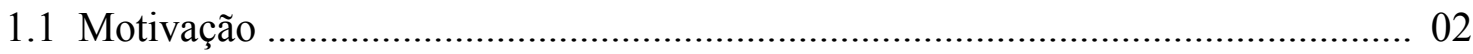

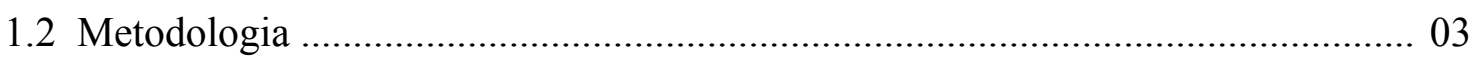

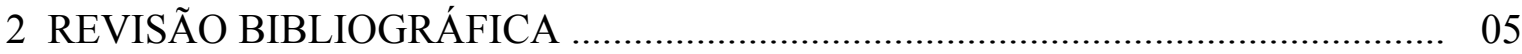

2.1 Elemento combustível utilizado em reatores a água pressurizada (PWR) .......... 05

2.2 Comportamento sob irradiação de uma vareta combustível em regime

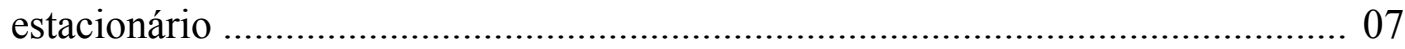

2.2.1 Comportamento sob irradiação da pastilha combustível de $\mathrm{UO}_{2}$.............. 07

2.2.1.1 Densificação induzida por irradiação ................................................ 08

2.2.1.2 Trincamento e relocação da pastilha combustível ............................ 10

2.2.1.3 Reestruturação do combustível ....................................................... 11

2.2.1.4 Redistribuição dos produtos de fissão ............................................. 13

2.2.1.5 Formação de plutônio ......................................................................... 14

2.2.1.6 Efeito dos gases de fissão ........................................................... 15

2.2.1.7 Fluência do combustível devido à irradiação ................................. 17

2.2.2 Comportamento sob irradiação do revestimento de Zircaloy-4 ................. 18

2.2.2.1 Efeito da irradiação nas propriedades mecânicas do Zircaloy-4 ..... 18

2.2.2.2 Efeito de irradiação na fluência do Zircaloy-4 .............................. 19

2.2.2.3 Crescimento devido à irradiação do Zircaloy-4 ............................. 20

2.2.2.4 Corrosão do revestimento e absorção de hidrogênio ......................... 21

2.3 Comportamento da vareta combustível sob condições de alta queima ................. 22

2.3.1 Efeito das condições de alta queima na pastilha combustível de $\mathrm{UO}_{2} \ldots \ldots .22$

2.3.1.1 Efeito da alta queima na reestruturação do combustível ................. 23

2.3.1.2 Efeito da alta queima na liberação de gases de Fissão ...................... 24

2.3.1.3 Efeito da alta queima na condutividade térmica do $\mathrm{UO}_{2} \ldots \ldots \ldots \ldots \ldots . . \ldots 26$ 
2.3.2 Efeito das condições de alta queima no revestimento de Zircaloy-4 28

2.3.2.1 Efeito da alta queima na corrosão do revestimento pelo

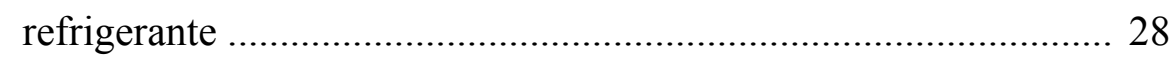

2.3.2.2 Efeito da alta queima na hidretação do revestimento ..................... 29

2.3.2.3 Efeito da alta queima nas propriedades mecânicas do revestimento ........................................................................ 30

2.3.2.4 Interação mecânica entre a pastilha e o revestimento (PCMI) em regimes de alta queima .......................................................... 30

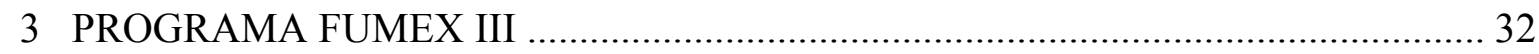

4 ANÁLISE DOS PROGRAMAS COMPUTACIONAIS FRAPCON-3.4A E FRAPTRAN-1.4 37

4.1 Características do programa computacional FRAPCON-3.4a .......................... 37

4.2 Características do programa computacional FRAPTRAN-1.4 ......................... 43

5 COMPARAÇÃO DOS RESULTADOS OBTIDOS ATRAVÉS DOS CÓDIGOS FRAPCON-3.4A E FRAPTRAN-1.4 COM OS DADOS FORNECIDOS PELO PROGRAMA EXPERIMENTAL FUMEX III …................................................ 48

5.1 Comparação dos dados fornecidos pelo programa FRAPCON-3.4a com os dados fornecidos pelo experimento IFPE/US-PWR-16x16 LTA (NEA-1738/01) 48

5.1.1 Simulação computacional de uma vareta combustível tipo TSQ002 com o código FRAPCON-3.4a . 49

5.1.2 Comparação dos dados obtidos por meio da simulação computacional com os dados experimentais 50

5.1.2.1 Temperatura central da vareta combustível ............................. 50

5.1.2.2 Liberação de gás de fissão ....................................................... 51

5.1.2.3 Volume livre no interior da vareta combustível ........................... 54

5.1.2.4 Pressão interna da vareta combustível ........................................ 54

5.2 Comparação dos dados fornecidos pelo programa FRAPCON-3.4a com os dados fornecidos pelo experimento IFPE/RISOEIII (NEA-1493/17) .................. 57

5.2.1 Simulação computacional da vareta combustível utilizada no experimento RISOEIII-GE7 através do código FRAPCON-3.4a . 58 
5.2.2 Comparação dos dados obtidos através da simulação computacional com os dados experimentais 58

5.2.2.1 Temperatura central da vareta combustível .................................. 58

5.2.2.2 Liberação de gases de fissão ..................................................... 59

5.3 Comparação dos dados fornecidos pelo programa FRAPTRAN-1.4 com os dados fornecidos pelo experimento IFPE/NSRR-FK1 NEA-1724/01

5.3.1 Simulação computacional da vareta combustível utilizada no experimento IFPE/NSRR-FK1 NEA-1724/01 através dos códigos FRAPCON-3.4a e FRAPTRAN-1.4 64

5.3.2 Comparação dos Dados Obtidos Através da Simulação Computacional com os Dados Experimentais 65

5.3.2.1 Temperatura Central da Pastilha Combustível ........................... 66

5.3.2.2 Pressão interna da vareta combustível ...................................... 67

5.3.2.3 Alongamento da coluna de pastilhas combustíveis ................... 70

5.3.2.4 Alongamento do revestimento .............................................. 70

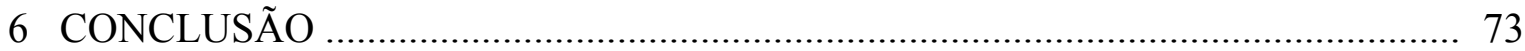

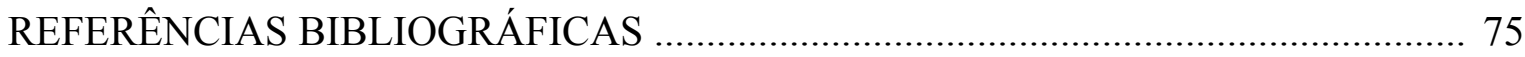

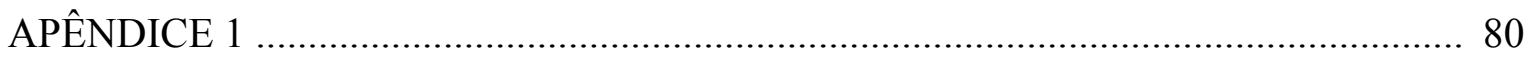

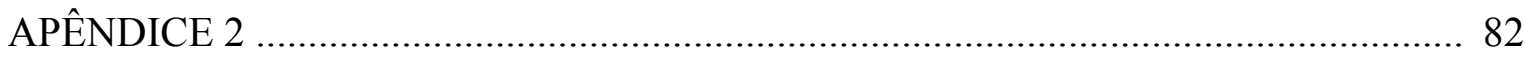

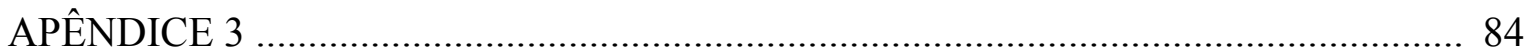




\section{INTRODUÇÃO}

Atualmente, diante de um quadro de crescente consumo de energia elétrica por parte da sociedade industrializada, a opção nuclear tem se tornado cada vez mais uma alternativa a ser considerada. Entretanto, para se tornar mais competitiva em meio a diversas outras opções de geração de energia elétrica, a operação das centrais nucleares necessita ser otimizada, sem que aspectos relacionados à segurança operacional sejam negligenciados.

Dentro deste quadro, diversos estudos tem sido realizados pelos envolvidos com a área nuclear visando otimizar os procedimentos operacionais empregados pelas centrais nucleares. Um desses estudos envolve a redução dos custos associados à operação de uma central nuclear através da otimização do ciclo do combustível nuclear. Para atingir este objetivo, torna-se necessário obter um maior aproveitamento do combustível nuclear, fazendo com que o mesmo permaneça por um maior período de tempo no interior do núcleo do reator nuclear, aproveitando ao máximo sua capacidade de produção de energia. Tecnicamente, este procedimento é denominado como extensão da queima do combustível, ou ainda, como extensão do queima.

O combustível nuclear atualmente utilizado nas centrais nucleares possui uma grande capacidade intrínseca de extensão de queima. Entretanto, o desempenho físico dos diversos constituintes do elemento combustível podem sofrer severas limitações de tempo de vida advindas desta extensão operacional, uma vez que são altamente degradados pelas severas condições presentes no interior do núcleo de um reator nuclear, condições essas que envolvem altos níveis de irradiação e elevados carregamentos térmicos e mecânicos.

Prever o comportamento dos componentes constituintes de um elemento combustível nessas condições operacionais é uma tarefa extremamente complexa, pois envolve a interação de um grande número de variáveis, as quais englobam as propriedades físico-químicas dos materiais envolvidos, metalurgia, mecânica estrutural, mecanismos de transferência de massa e de calor, apenas para citar alguns exemplos. Adicionado a isto, a exposição a longos períodos de irradiação implica em uma série da alterações na estrutura dos materiais empregados na construção do elemento combustível nuclear, acarretando significativas alterações de suas propriedades físicas.

Levando tudo isso em consideração, um grande esforço vem sendo realizado com a intensão de estudar o comportamento de elementos combustíveis nucleares sob condições de queima estendida (high burnup) e desenvolver modelos que representem estes 
comportamentos, para que possam ser utilizados em programas computacionais que simulem o desempenho de varetas combustíveis em condições de operação normais ou sob regimes de transientes.

Entretanto, grande parte desses modelos são empíricos e fornecem soluções aproximadas dos fenômenos que procuram representar. Como os programas computacionais utilizam dezenas desses modelos de forma interativa, os resultados gerados pelos códigos podem possuir um grau de incerteza relativamente elevado. Deste modo, é essencial que sejam realizados estudos que comparem os resultados fornecidos por esses programas computacionais com dados experimentais relacionados ao comportamento de varetas combustíveis.

Este é exatamente o objetivo do programa FUMEX III promovido pela Agência Internacional de Energia Atômica (IAEA - International Atomic Energy Agency). Este programa experimental tem por finalidade constituir uma base da dados relacionados ao desempenho de diversos tipos de elementos combustíveis, empregados em diferentes tipos de reatores nucleares, sob diversas condições operacionais, condições essas que envolvem regimes estacionário e de transiente, em condições de alta queima, além de dados relacionados a acidentes dos tipos LOCA (Loss of Coolant Accident) e RIA (Reactivity Initiated Accident).

Nos capítulos seguintes deste trabalho, são apresentadas as principais características de um elemento combustível nuclear utilizado em reatores de água leve pressurizada (PWR) bem como uma análise dos efeitos que as condições operacionais no interior do núcleo acarretam nas varetas combustíveis utilizadas nesses elementos. Também são realizadas três simulações visando determinar o comportamento dessas varetas combustíveis sob situações operacionais. Duas simulações são realizadas considerando regime estacionário e sob condições de alta queima. Para a realização dessas simulações é utilizado o código FRAPCON-3.4a. A outra simulação é realizada em regime transiente, considerando a ocorrência de um acidente tipo RIA. Para a realização desta simulação é utilizado o código FRAPTRAN-1.4.

\subsection{Motivação}

O desenvolvimento do presente trabalho foi motivado devido à necessidade de se obter um perfeito domínio no que se refere à compreensão e à utilização dos programas computacionais utilizados no processo de análise do desempenho de varetas combustíveis 
utilizadas em reatores de água pressurizada (PWR - Pressurized Water Reactor), em situações operacionais que envolvam regime permanente e sob a ação de transientes. $\mathrm{O}$ domínio desta habilidade é de fundamental importância no processo de projeto e validação do elemento combustível nuclear.

Outro fator que motivou a elaboração deste trabalho foi o de participar de um esforço mundial que tem por finalidade verificar a acurácia desses programas computacionais, fazendo com que os mesmos possam ser utilizados com segurança no processo de desenvolvimento, projeto e licenciamento do combustível nuclear.

\subsection{Metodologia}

A elaboração do presente trabalho se iniciou com uma revisão bibliográfica, a qual teve por objetivo estudar e compreender as principais características dos elementos combustíveis utilizados em reatores de água leve pressurizada (PWR) e o comportamento destes durante a operação no núcleo do reator nuclear. Esses estudos focaram nas consequências que os efeitos da irradiação e dos carregamentos térmicos e mecânicos acarretam nos principais componentes da vareta combustível, ou seja, na pastilha combustível de $\mathrm{UO}_{2}$ e no revestimento de Zircaloy-4. Ênfase especial foi dada ao estudo de combustíveis submetidos a regimes de alta queima, e às consequências que tal condição operacional causa no comportamento da vareta combustível. Os resultados deste estudo se encontram descritos no Capítulo 2 - Revisão Bibliográfica.

Após a realização da revisão bibliográfica, foi realizado um estudo do programa experimental FUMEX III, que tem por objetivo fornecer dados que possam melhorar a eficiência dos códigos computacionais utilizados para a simulação do desempenho do combustível sob condições de irradiação. Este estudo se encontra descrito no Capítulo 3 O programa FUMEX III.

Em seguida, foi efetuado um estudo da estrutura dos códigos computacionais FRAPCON-3.4a e FRAPTRAN-1.4, incluindo a análise dos procedimentos necessários para a montagem dos arquivos de dados de entrada para a execução dos programas, além de serem realizados estudos relativos à interpretação dos resultados fornecidos pelos códigos. O estudo realizado nesses programas computacionais se encontra descrito no Capítulo 4 - Análise dos Programas Computacionais FRAPCON-3.4a e FRAPTRAN-1.4.

Uma vez compreendidos os procedimentos a serem utilizados para a execução dos programas computacionais FRAPCON-3.4a e FRAPTRAN-1.4, foram selecionados três 
casos da base de dados FUMEX III para serem executados pelos códigos, com a finalidade de comparar os resultados fornecidos através da simulação computacional com os dados obtidos por meio dos programas experimentais realizados pelo FUMEX III. Para condições de regime estacionário, foram selecionados os experimentos IFPE/US-PWR-16x16 LTA (NEA-1738/01) e IFPE/SPC-RE-GINNA (NEA-1623/01) e em condições de regime transiente, considerando a ocorrência de um acidente tipo RIA, foi selecionado o experimento IFPE/NSRR-FK1 (NEA-1724/01).

Os procedimentos realizados e os resultados obtidos na comparação entre os resultados experimentais fornecidos pela base de dados FUMEX III com os dados obtidos por intermédio da simulação computacional utilizando os códigos FRAPCON-3.4a e FRAPTRAN-1.4 se encontram descritos no Capítulo 5 - Comparação dos Resultados Obtidos pelos Códigos Computacionais FRAPCON-3.4a e FRAPTRAN-1.4 com os Dados Fornecidos pelo Programa Experimental FUMEX III.

Finalmente, o Capítulo 6 apresenta as conclusões obtidas através dos estudos e das simulações computacionais realizadas neste trabalho. 


\section{REVISÃO BIBLIOGRÁFICA}

Entender o comportamento do combustível nuclear em condições operacionais é de fundamental importância para se compreender a estrutura e o funcionamento dos programas computacionais que simulam o comportamento de uma vareta combustível.

Neste capítulo, será realizado um estudo dos principais fenômenos que ocorrem em uma vareta combustível em condições operacionais, ou seja, quando submetidas à irradiação e a elevados carregamentos térmicos e mecânicos.

\subsection{Elemento Combustível Utilizado em Reatores a Água Pressurizada (PWR).}

O elemento combustível de um reator nuclear PWR (Figura 2.1) é composto essencialmente de um conjunto de varetas combustíveis, rigidamente posicionadas em uma estrutura metálica, formada por grades espaçadoras, tubos guias e dois bocais, um inferior e um superior. Nos tubos guias são inseridas as barras de controle da reação nuclear. As grades espaçadoras são unidas a estes tubos por solda eletrônica.

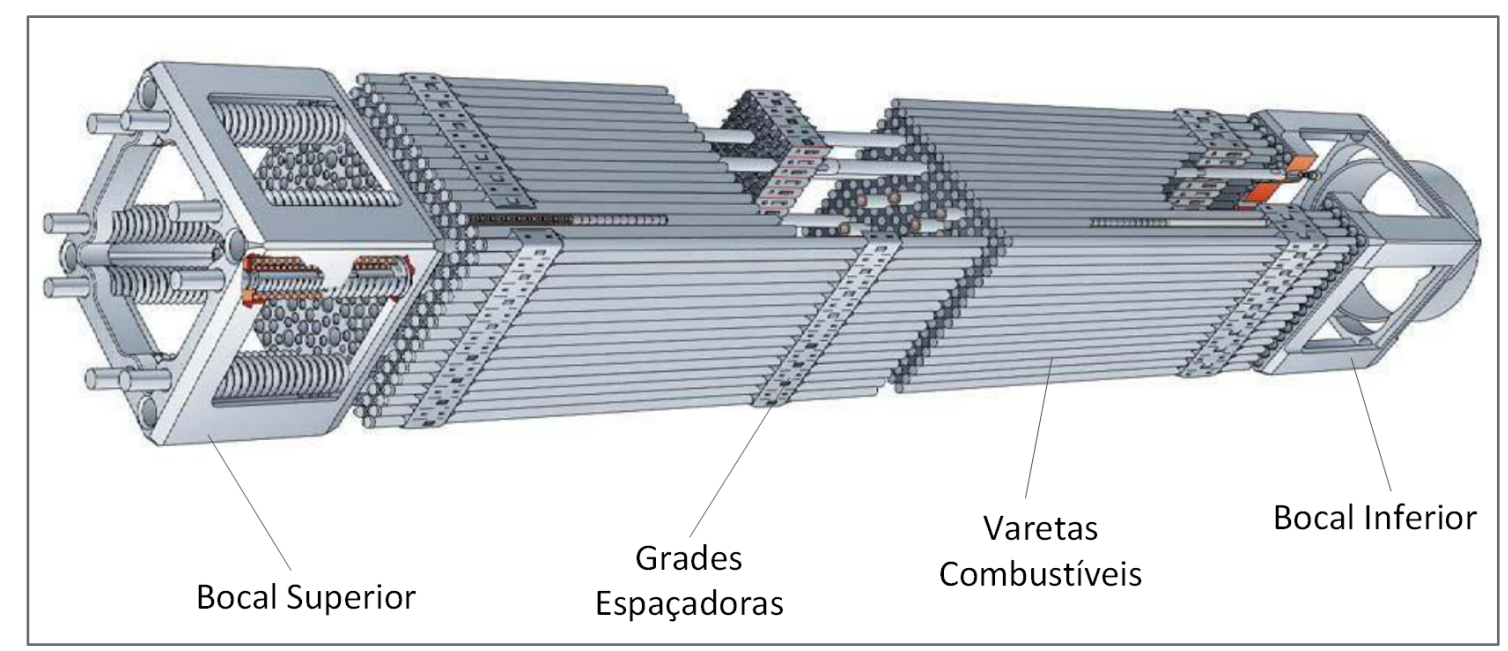

Figura 2.1 - Elemento combustível típico de um reator PWR (Pressurized Water Reactor).

Fonte: Westinghouse Electric Company.

No elemento combustível, cada vareta combustível é composta de um revestimento tubular metálico no interior do qual se encontram empilhadas pastilhas cerâmicas de combustível nuclear. Em cada extremidade desta coluna de pastilhas combustíveis são colocadas pastilhas de alumina $\left(\mathrm{Al}_{2} \mathrm{O}_{3}\right)$ com a finalidade de servir como isolante térmico. 
Para manter unida esta coluna de pastilhas, é colocada uma mola na parte superior da vareta combustível. Esta mola também possui a função de criar um espaço no interior da vareta combustível para o acomodamento dos gases de fissão produzidos no processo de irradiação. Finalmente, nas extremidades do tubo de revestimento, são soldados tampões de modo a tornar o tubo estanque em suas extremidades, impedindo desta maneira que os produtos de fissão gerados durante a operação do combustível sejam liberados para o fluído refrigerante. A Figura 2.2 ilustra a estrutura típica de uma vareta combustível utilizada em reatores PWR.

Nas análises que serão realizadas no presente trabalho será considerada uma vareta combustível típica utilizada em reatores PWR, a qual é constituída de pastilhas de dióxido de urânio $\left(\mathrm{UO}_{2}\right)$ como material combustível e Zircaloy-4 como material de revestimento.

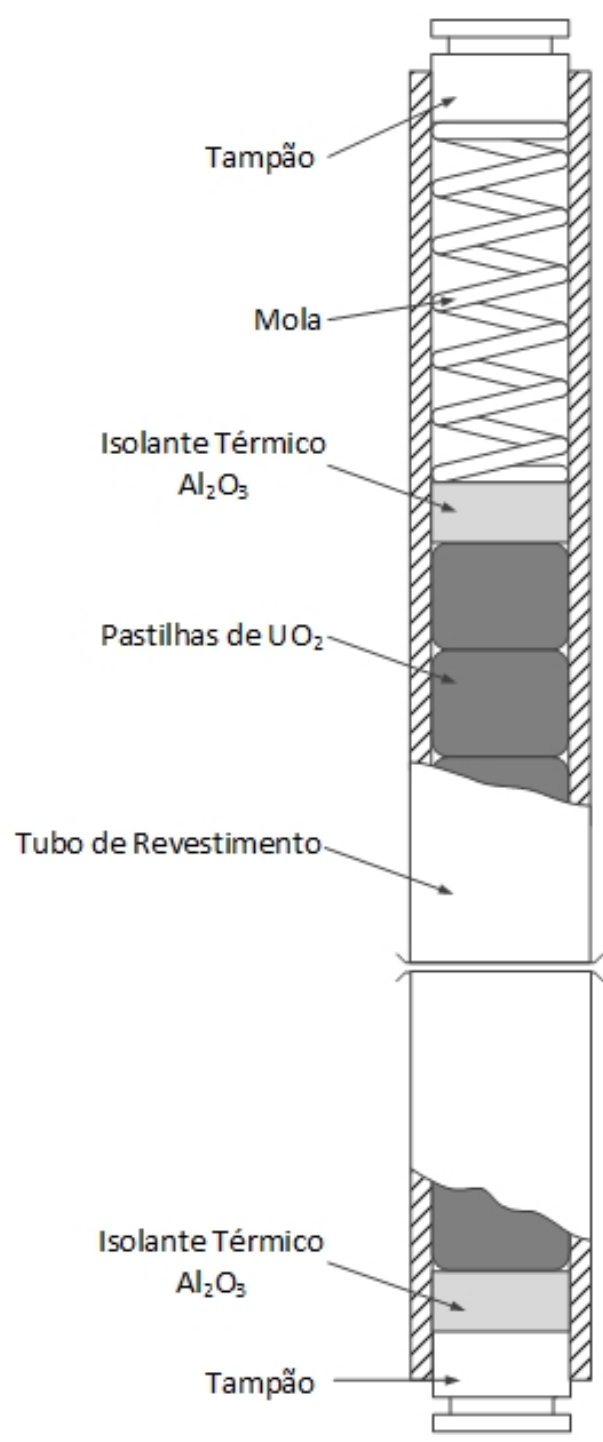

Figura 2.2 - Vareta combustível tipicamente utilizada em reatores PWR.

Fonte: Autor. 


\subsection{Comportamento sob Irradiação de uma Vareta Combustível em Regime Estacionário.}

Durante a operação no núcleo de um reator nuclear, o elemento combustível encontra-se em um ambiente bastante severo, envolvendo altos níveis de radiação e com a aplicação de elevados carregamentos térmicos e mecânicos. Isto faz com que ocorram numerosos e complexos fenômenos nos diversos componentes de um elemento combustível, fenômenos estes que ocasionam uma série de alterações químicas, físicas, metalúrgicas e estruturais.

Neste item, serão estudados os efeitos decorrentes da irradiação e da aplicação de cargas térmicas em varetas combustíveis constituídas de um revestimento de Zircaloy-4 e de pastilhas de $\mathrm{UO}_{2}$. Inicialmente, serão analisados os comportamentos da pastilha combustível e do revestimento em condições de queima normal, ou seja, quando submetidos até uma queima de aproximadamente $45 \mathrm{MWd} / \mathrm{kgU}$ (JERNKVIST e MARRIH, 2004). Em seguida, será realizado uma análise no impacto que queimas superiores a este valor acarretam no comportamento da vareta combustível.

\subsubsection{Comportamento sob Irradiação da Pastilha Combustível de $\mathrm{UO}_{2}$.}

Conforme descrito por OLANDER (1976), FROST (1982) e ROBERTSON (1969), diversos estudos foram realizados com finalidade de compreender o comportamento de uma pastilha combustível no interior de um reator nuclear. Esses estudos demonstraram a ocorrência de grandes alterações na geometria, dimensões, composição e microestrutura durante o processo de irradiação.

Por se tratar de um combustível cerâmico, além da intensa radiação, as pastilhas combustíveis encontram-se submetidas a severas condições térmicas. Devido à baixa condutividade térmica da pastilha de $\mathrm{UO}_{2}$, o calor gerado devido às fissões nucleares que ocorrem no interior da pastilha encontra uma grande resistência à sua propagação, o que causa enormes diferenças de temperaturas entre a região central e a região periférica da pastilha combustível. Uma pastilha de $\mathrm{UO}_{2}$ típica opera com temperaturas próximas do ponto de fusão em sua região central e com temperaturas pouco superiores às do fluído refrigerante em sua região periférica, o que implica em um gradiente de temperatura radial da ordem de $2000-2200{ }^{\circ} \mathrm{C} / \mathrm{cm}$ (OLANDER, 1976). Um gradiente térmico de tal ordem causa um rápido trincamento da pastilha combustível devido ao surgimento de tensões 
térmicas. Além disso, o processo de irradiação fornece condições para que se manifestem vários mecanismos de transporte no combustível, os quais acarretam alterações significativas na microestrutura, composição e dimensão do combustível. De acordo com ROY e SAH (1985), os principais efeitos que a irradiação e elevados gradientes térmicos causam na pastilha combustível de $\mathrm{UO}_{2}$ podem ser observado na Figura 2.3. Esses efeitos podem ser divididos em cinco categorias principais: (1) densificação; (2) reestruturação; (3) redistribuição do combustível e produtos de fissão; (4) efeitos relacionados aos gases de fissão: inchamento e liberação de gases e; (5) fluência devido à irradiação. A Figura 2.3 ilustra as diversas alterações observadas em uma pastilha combustível de $\mathrm{UO}_{2}$, alterações essas ocasionadas pelos efeitos da irradiação e dos elevados gradientes térmicos aos quais a pastilha é submetida em condições operacionais.

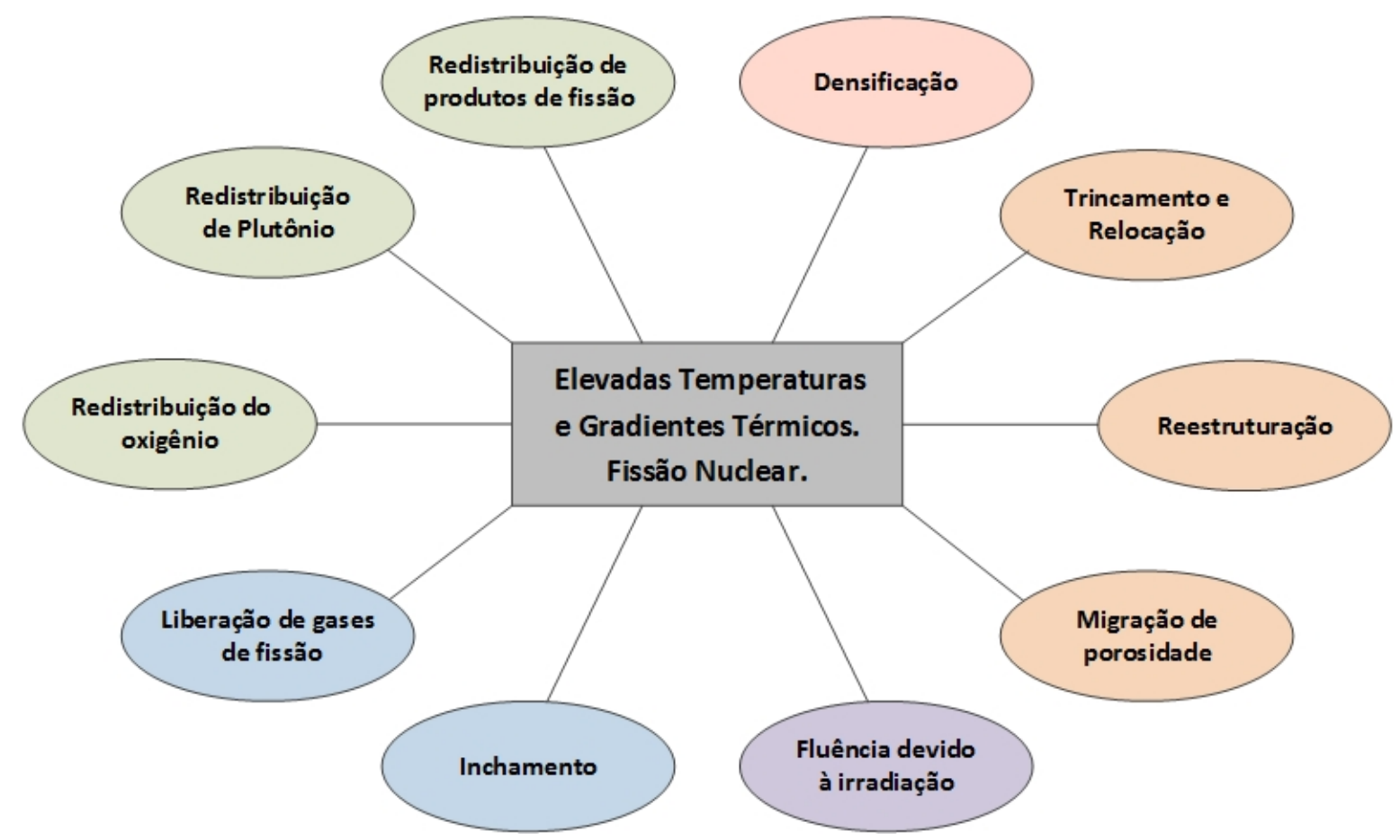

Figura 2.3 - Alterações observadas em uma pastilha de $\mathrm{UO}_{2}$ durante a irradiação devido aos elevados gradientes de temperaturas e à radiação.

Fonte: Roy e Sah, 1985.

\subsubsection{Densificação induzida por Irradiação.}

Atualmente, as pastilhas combustíveis utilizadas em reatores PWR possuem uma densidade de aproximadamente $95 \%$ da densidade teórica do $\mathrm{UO}_{2}$. A porosidade existente nessas pastilhas é constituída por poros pequenos, de dimensões aproximadas de $1 \mu \mathrm{m}$, 
resultantes do processo de sinterização, e por poros com dimensões maiores que $10 \mu \mathrm{m}$, resultantes da adição de substâncias orgânicas ao pó de $\mathrm{UO}_{2}$ com a finalidade de medir a densidade final da pastilha. Essa porosidade inicial existente na pastilha combustível é a responsável pelo fenômeno da densificação (SMALL, 1987).

Segundo OLANDER (1976) e SMALL (1987), a densificação é um fenômeno que ocorre nos estágios iniciais da irradiação de combustíveis cerâmicos e é ocasionado devido às interações dos fragmentos de fissão com o material combustível, que resulta em um encolhimento e dissolução da porosidade presente na pastilha combustível. Este processo ocorre em duas fases:

i. Quando um fragmento de fissão atravessa um grão do material combustível e rompe os poros que se encontram em seu caminho, transformando os poros em vacâncias na rede cristalográfica do material combustível;

ii. Essas vacâncias migram então para os contornos de grão. A migração das vacâncias para os contornos de grão resulta na densificação do combustível.

A Figura 2.4 ilustra, de modo esquemático, a manifestação do fenômeno de densificação.

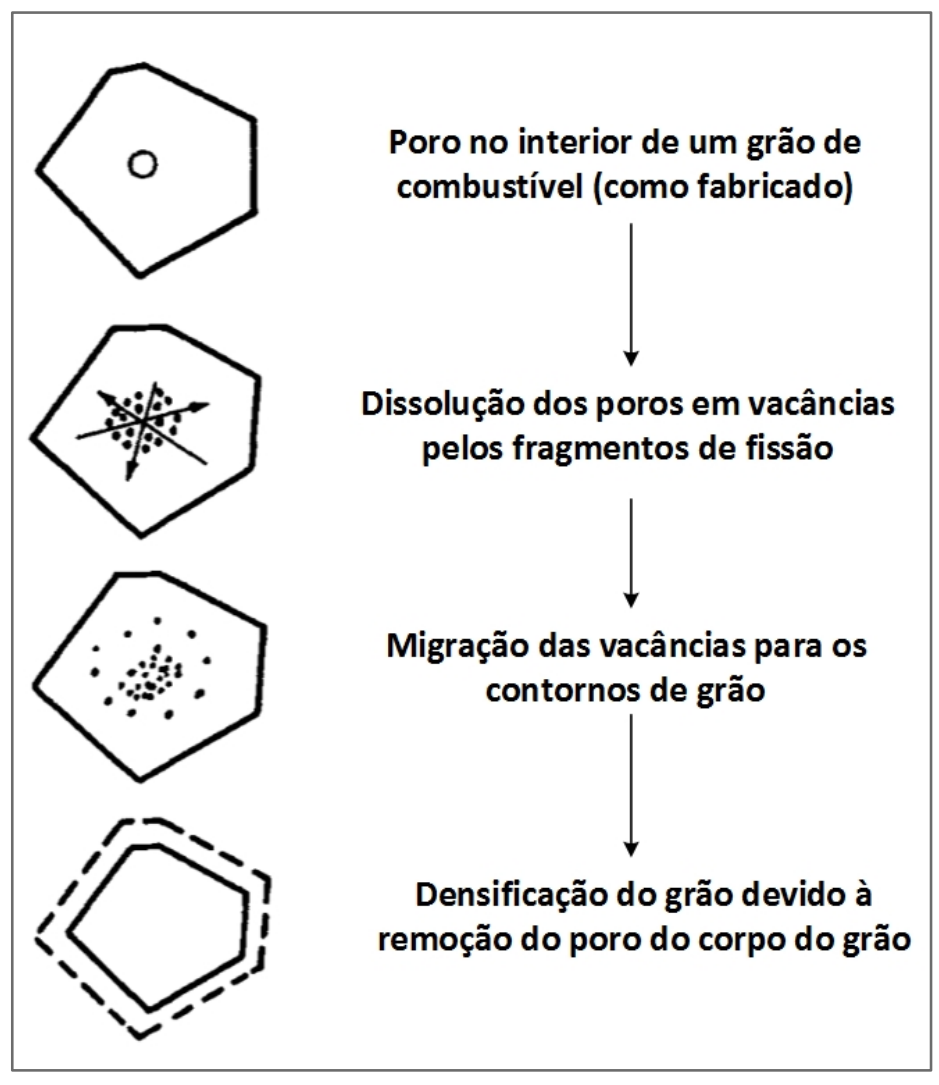

Figura 2.4 - Mecanismo de densificação devido à irradiação.

Fonte: CHUBB et al., 1975. 


\subsubsection{Trincamento e Relocação da Pastilha Combustível}

Durante a primeira rampa de potência aplicada ao elemento combustível, ocorre uma elevada diferença de temperatura entre a região central e a região periférica da pastilha combustível. Este alto gradiente térmico implica no aparecimento de deformações termo-elásticas, que vão se elevando até que o limite de ruptura da pastilha combustível seja atingido, acarretando no trincamento da mesma. Em reatores típicos de água leve LWR (Light Water Reactor), o limite de ruptura da pastilha combustível é atingido quando ocorre uma taxa de geração de calor linear de aproximadamente $5 \mathrm{~kW} / \mathrm{m}$ (MAKI e MEYER, 1978).

Uma vez que o limite de ruptura é excedido, poderão ocorrer deslocamentos repentinos de pedaços da pastilha combustível, os quais irão reduzir a dimensão da folga (gap) existente entre a pastilha combustível e a superfície interna do revestimento. Este aumento aparente do diâmetro da pastilha combustível devido ao trincamento, que acarreta na diminuição da folga entre a pastilha combustível e o revestimento, é denominado relocação da pastilha combustível (OGUMA, 1983). A Figura 2.5 mostra uma pastilha combustível fragmentada. Nesta imagem é facilmente observável o espaçamento entre as trincas e as variações do espaço existente entre a pastilha combustível e o revestimento.

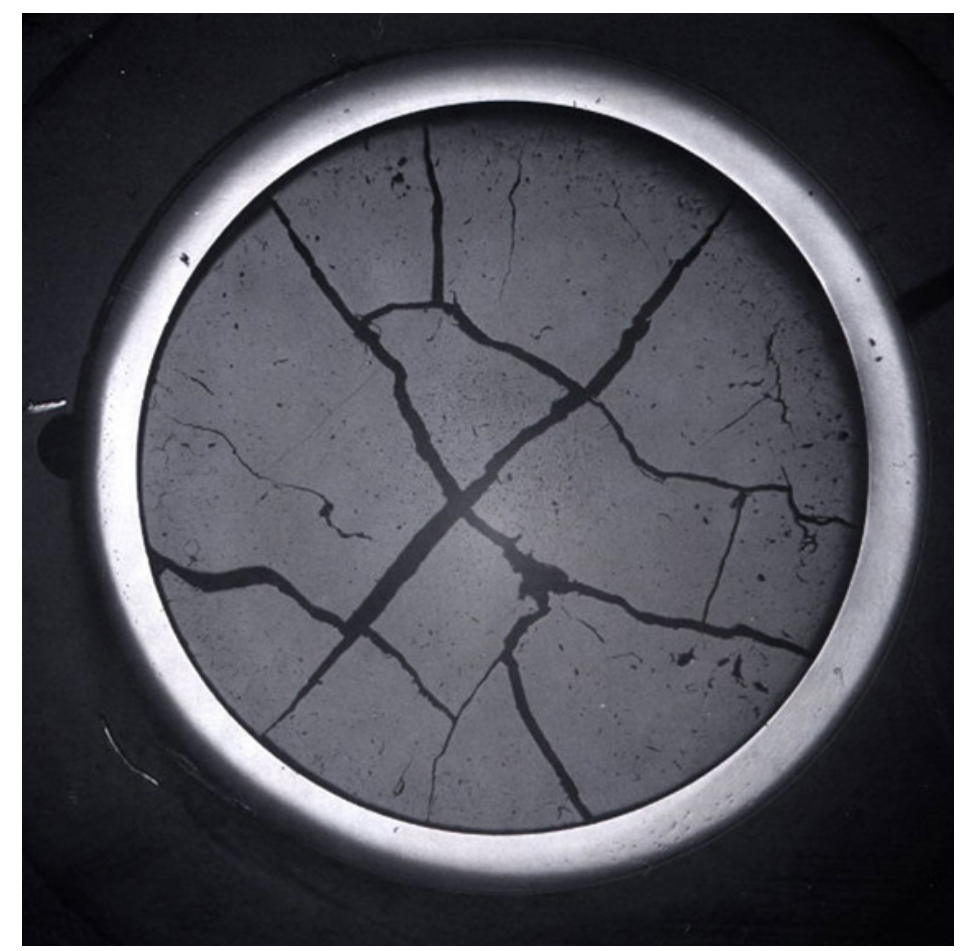

Figura 2.5 - Trincamento e relocação de uma pastilha combustível. Fonte: BAHL et al., 1979. 
Com o aumento da potência, ocorrem novas relocações, resultantes da deformação termo-elástica de cada um dos fragmentos da pastilha. Se o contato com o revestimento é atingido, os vazios ocasionados pelo trincamento da pastilha são comprimidos e acomodam uma parte da expansão térmica da pastilha combustível.

O trincamento e a relocação da pastilha combustível acarreta diversas alterações no comportamento da vareta combustível. Os principais efeitos observados são os seguintes (MAKI e MEYER, 1978):

- Alteração das características da condução do calor gerado na pastilha combustível, causada pelo surgimento das trincas e pelas alterações das dimensões do gap;

- Maior liberação dos gases de fissão, devido ao aumento das superfícies livres da pastilha combustível e ao trincamento da região central da pastilha, a qual possui uma maior concentração de gases de fissão armazenados no combustível;

- Interação entre os fragmentos da pastilha combustível com o revestimento. Devido ao fato da expansão térmica da pastilha combustível ser maior que a do revestimento, podem surgir grandes forças de contato entre os fragmentos da pastilha combustível e a superfície interna do revestimento, levando à ocorrência do fenômeno denominado PCMI (Pellet Clad Mechanical Interaction). Adicionalmente, produtos de fissão liberados, tais como iodo e/ou césio, atacam quimicamente o revestimento, causando um efeito denominado PCCI (Pellet Clad Chemical Interaction). Os efeitos combinados de PCMI e PCCI podem levar à falha do revestimento por corrosão sob tensão, ou SCC (Stress Corrosion Cracking).

\subsubsection{Reestruturação do combustível.}

De acordo com OLANDER (1976), a microestrutura de uma pastilha combustível de $\mathrm{UO}_{2}$ não irradiada consiste de grãos equiaxiais com diâmetros de 5 a $15 \mu \mathrm{m}$ e com porosidade uniformemente distribuída. Entretanto, durante a operação no núcleo do reator, ocorrem uma série de alterações na microestrutura do combustível, alterações essas ocasionadas pela irradiação e, em maior intensidade, pelas elevadas temperaturas presentes na pastilha combustível.

Conforme pode ser observado nas Figuras 2.6 e 2.7, a seção transversal de um pastilha combustível de $\mathrm{UO}_{2}$ irradiada mostra zonas concêntricas com microestruturas 
alteradas, que são indicativas das temperaturas aplicadas ao combustível durante a irradiação.

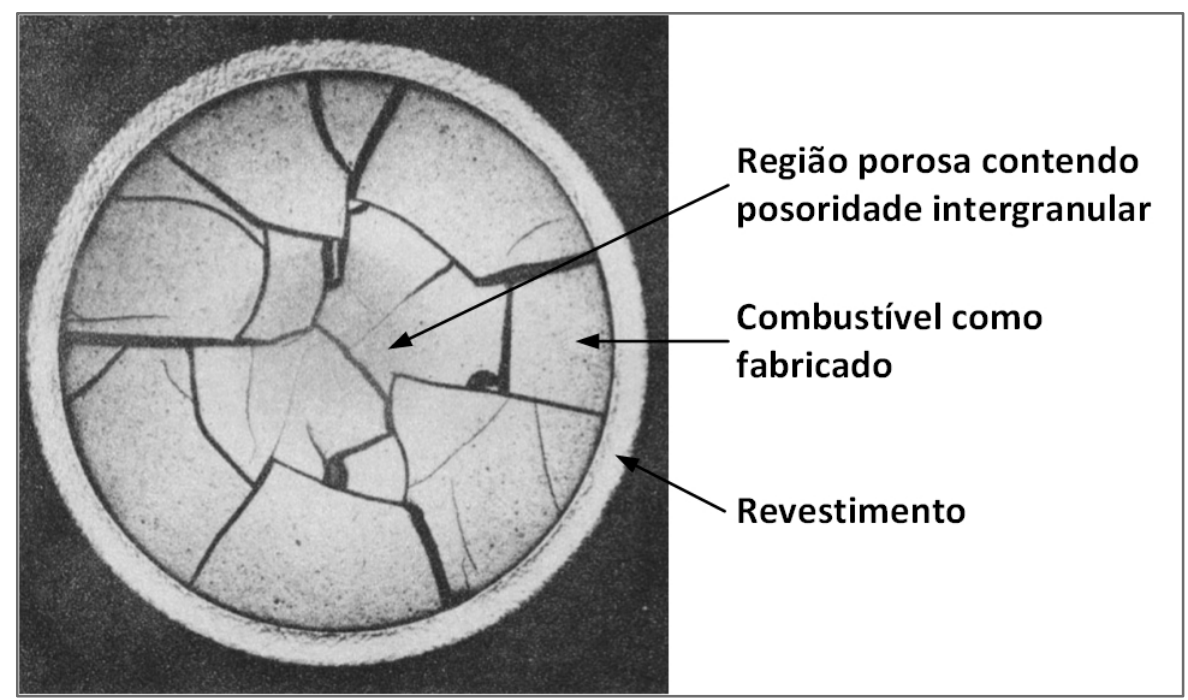

Figura 2.6 - Seção transversal de uma pastilha combustível de $\mathrm{UO}_{2}$ irradiada revelando a formação de poros na região central do combustível (ampliação de 6x). A temperatura máxima na região central do combustível foi estimada em $1250{ }^{\circ} \mathrm{C}$.

Fonte: BAHL et al., 1979.

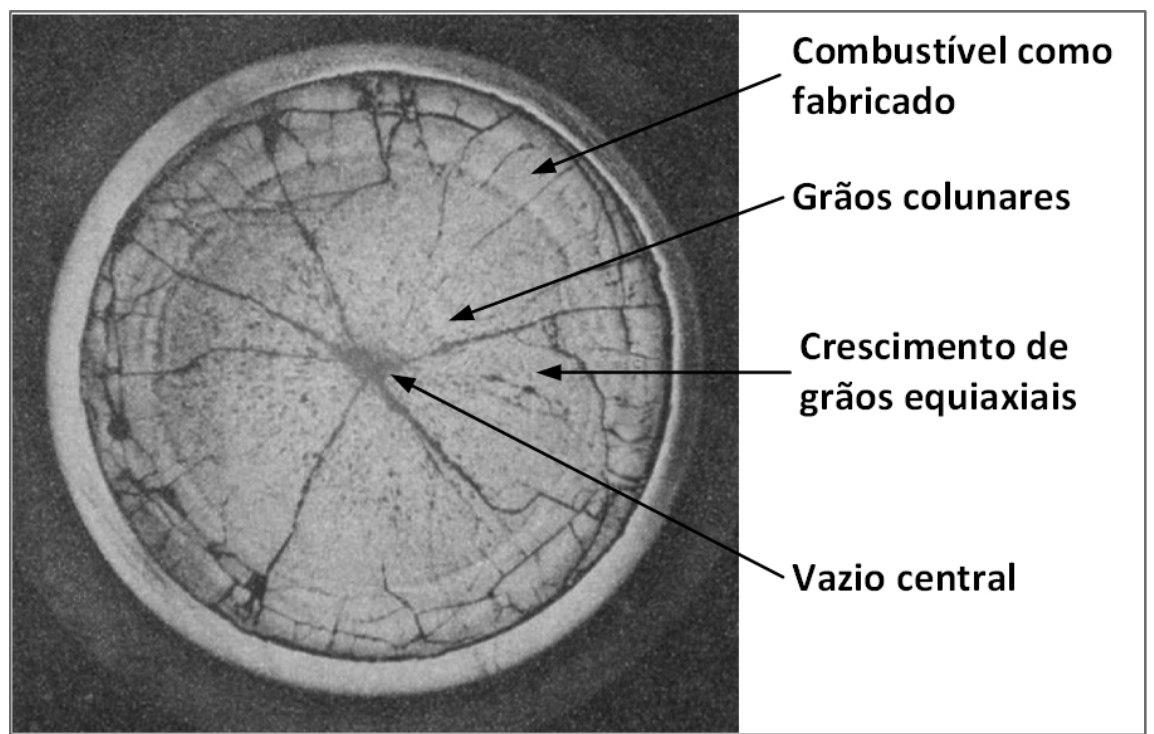

Figura 2.7 - Reestruturação de uma pastilha combustível de $\mathrm{UO}_{2}$ (amplificação de 5x). A temperatura máxima na região central do combustível foi estimada em $2200{ }^{\circ} \mathrm{C}$.

Fonte: BAHL et al., 1979.

A reestruturação do combustível envolve dois tipos de crescimento de grãos. Acima de aproximadamente $1500{ }^{\circ} \mathrm{C}$ os grãos crescem uniformemente, formando uma estrutura com grandes grão equiaxiais. Acima de cerca de $1800{ }^{\circ} \mathrm{C}$, inicia-se o crescimento 
direcional de grãos, o que leva à formação de logos e estritos grãos colunares, orientados para a região central da pastilha combustível (FROST, 1982). A formação dos grãos colunares radialmente orientados envolve movimentos dos poros para os gradientes de temperaturas mais elevados. O movimento desses poros para a região central da pastilha combustível resulta em grãos colunares de alta densidade e a formação de um vazio central. A Figura 2.8 ilustra as zonas com diferentes tipos de grãos em função da variação da temperatura.

Além das alterações na microestrutura da pastilha combustível, um outro processo, puramente mecânico, pode se manifestar quando ocorrem rápidas alterações na potência gerada pelo reator. Essas rampas de potência acentuadas acarretam rápidas mudanças na temperatura da pastilha combustível levando ao aparecimento de tensões térmicas e ao consequente craqueamento da pastilha combustível. Entretanto, durante operações prolongadas à potencia constante, as trincas irão curar devido a processos de difusão. Deste modo, as alterações na microestrutura do combustível irão se alterar continuamente com o tempo e com a queima.

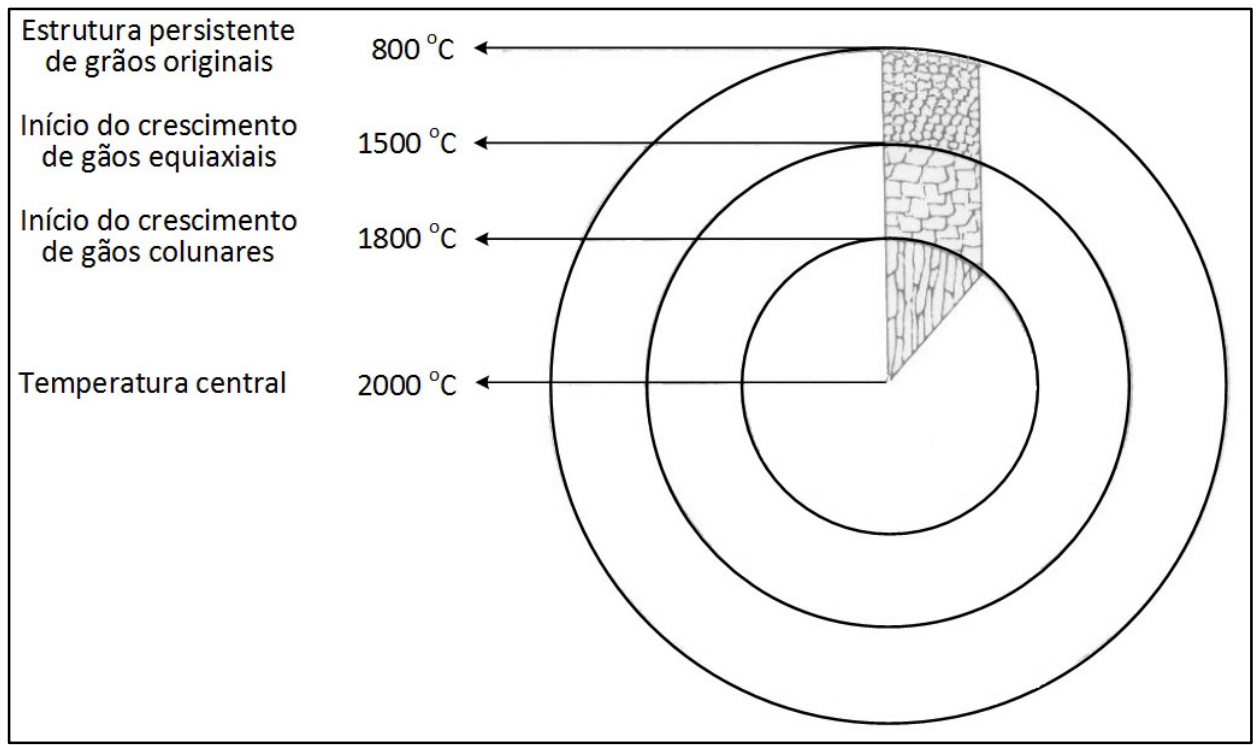

Figura 2.8. Representação esquemática das alterações microestruturais em uma pastilha combustível de $\mathrm{UO}_{2}$ altamente irradiada.

Fonte: FROST, 1982.

\subsubsection{Redistribuição dos produtos de fissão.}

Átomos de mais de 30 elementos são produzidos no interior do combustível nuclear como resultado do processo de fissão (OLANDER, 1976). Vários isótopos desses 
elementos possuem meia-vida bastante curta e decaem rapidamente. Entretanto, cerca de 120 isótopos possuem meia-vida considerável e podem afetar a composição química do combustível após períodos apreciáveis de irradiação.

Devido ao gradiente térmico presente na pastilha combustível, alguns produtos de fissão se movem a partir da região em que foram criados. Deste modo, certas regiões do combustível podem possuir uma maior concentração desses produtos de fissão, o que pode afetar, localmente, as propriedades químicas e físicas do material combustível. Uma das mais importantes consequências da redistribuição dos produtos de fissão é a possibilidade de ataque químico ao material do revestimento por parte do combustível.

De acordo com OLANDER (1976) as principais características dos produtos de fissão são as seguintes:

i. Os gases nobres $\mathrm{Kr}$ (criptônio) e Xe (xenônio) são insolúveis na matriz do combustível e podem formar bolhas intragranulares e intergranulares (nos contornos de grãos). Podem ainda ser liberados da pastilha combustível para o volume livre da vareta combustível;

ii. Os elementos $\mathrm{Zr}$ (zircônio), $\mathrm{Nb}$ (nióbio), Ce (cério), $\mathrm{Pr}$ (praseodímio) , Ba (bário) e Sr (estrôncio) estão presentes como óxidos não voláteis no combustível, e não se redistribuem;

iii. Metais nobres como o $\mathrm{Ru}$ (rutênio), $\mathrm{Rh}$ (ródio), $\mathrm{Pd}$ (paládio) e Mo (molibdênio) encontram-se presentes na forma elementar e migram significativamente;

iv. Os produtos de fissão voláteis Cs (césio), Rb (rubídio), I (iodo), Te (telúrio), $\mathrm{Sb}$ (antomônio) e Cd (cádmio) tendem a migrar para as regiões mais frias do combustível, ou seja, para a região periférica da pastilha combustível. Quando ocorre o contato entre a superfície externa da pastilha combustível com a parede interna do revestimento, a concentração desses elementos nesta região pode causar o ataque químico do revestimento.

\subsubsection{Formação de Plutônio}

As pastilhas combustíveis utilizadas em reatores de água pressurizada são, em geral, constituídas apenas de $\mathrm{UO}_{2}$. Entretanto, durante o processo de irradiação, uma parte do $\mathrm{U}^{238}$ presente nessas pastilhas é convertido $\mathrm{em}^{2{ }^{239}}$ através da captura radiativa de nêutrons rápidos. A quantidade de plutônio presente no combustível aumenta de modo 
progressivo com a queima, podendo atingir valores da ordem de 1,2\% da composição do combustível quando uma queima da ordem de $50 \mathrm{MWd} / \mathrm{kgU}$ é atingida.

Por ser um elemento físsil, o plutônio gerado no interior da pastilha combustível contribui com o processo de geração de energia e, em queimas superiores a $40 \mathrm{MWd} / \mathrm{kgU}$, se torna o elemento preponderante neste processo, compensando a depleção do $U^{235}$ (TERREMOTO, 2012) e (LASSMAN et al., 1993).

\subsubsection{Efeito dos Gases de Fissão}

Uma quantidade apreciável dos produtos de fissão, em torno de 15\%, são constituídos pelos gases nobres Xe (xenônio) e $\mathrm{Kr}$ (criptônio), os quais possuem uma solubilidade extremamente baixa na matriz do combustível (OLANDER, 1976) e (ROY e SAH, 1985). Dois importantes efeitos são decorrentes da produção desses gases de físsão:

i. Se esses gases são liberados, eles acarretam no aumento da pressão interna da vareta combustível, causando maiores tensões aplicadas ao revestimento;

ii. Se esses gases permanecem aprisionados no combustível, eles geram bolhas de gás, o que causa o inchamento do combustível.

As alterações dimensionais do combustível devido ao inchamento, se excessivas, levam a uma significativa interação mecânica entre o combustível e o revestimento, a qual, frequentemente, causa a falha do revestimento. Esta falha pode ocorrer devido a trincas ocasionadas por corrosão sob tensão, falha esta denominada PCI (Pallet Clad Interaction) ou pela interação mecânica entre a pastilha e o revestimento, denominada PCMI (Pallet Clad Mechanical Interaction). A Figura 2.9 ilustra a seção transversal de uma vareta combustível com falha devido à PCI.

No que se refere ao processo de liberação de gases de fissão pela pastilha combustível de $\mathrm{UO}_{2}$, este pode ocorrer através de dois mecanismos: liberação atérmica e liberação térmica.

A liberação atérmica é provocada pelo recuo direto de fragmentos de fissão dentro de uma camada com espessura igual à distância penetrada por esses fragmentos (aproximadamente $10 \mu \mathrm{m}$ ). Deste modo, átomos de gás gerados próximos às superfícies externas da pastilha combustível podem escapar para o volume vazio da vareta combustível. Durante este processo de escape, esses átomos colidem elasticamente com outros átomos, causando também a ejeção desses outros átomos (OLANDER, 1976). A 
liberação de gás atérmica é o fenômeno predominante na pastilha de combustível de $\mathrm{UO}_{2}$ de reatores a água leve pressurizada operando em condições normais de potência, até um limite de queima de aproximadamente $40 \mathrm{MWd} / \mathrm{kgU}$. Dentro deste limite, a liberação atérmica de gases de fissão pode ser considerada como uma função praticamente linear com relação à queima do combustível, e apresenta uma liberação muito baixa, de até 1\% do total de gases gerados por fissão.

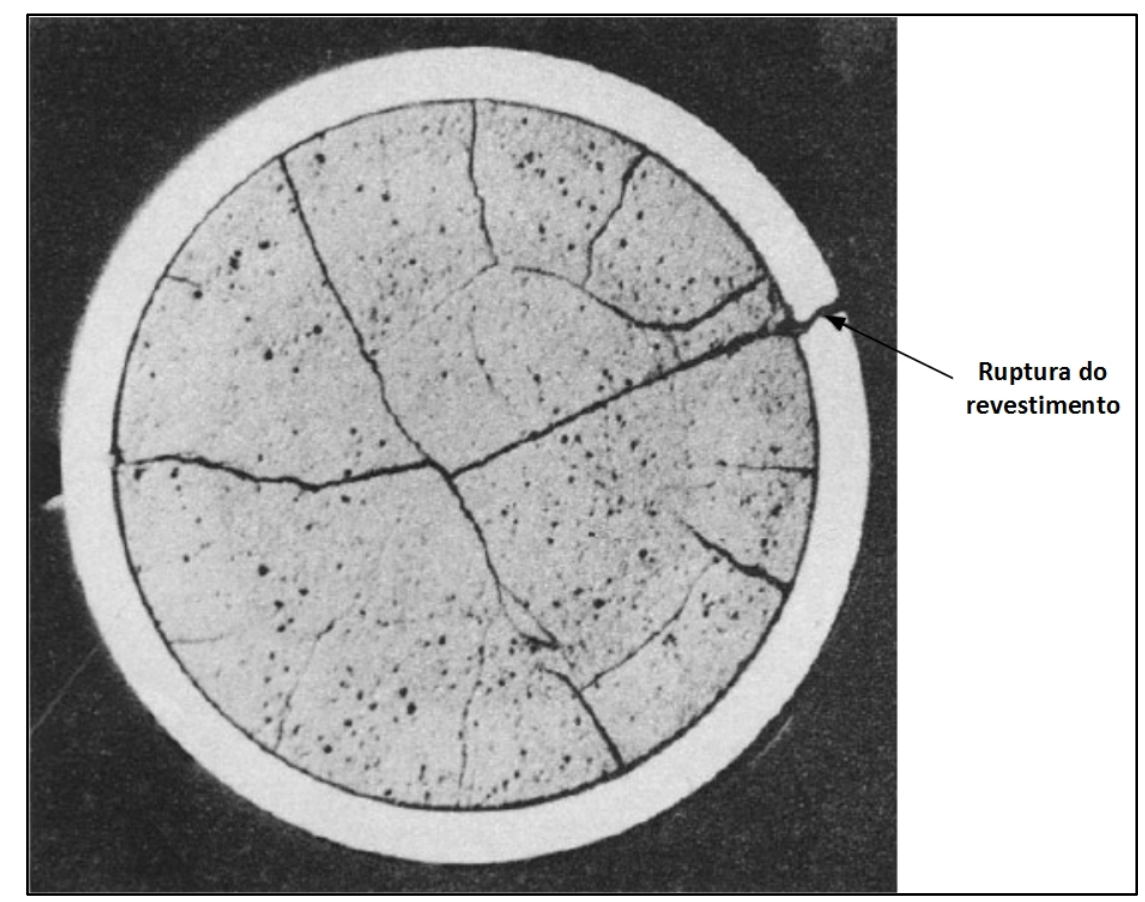

Figura 2.9 - Seção transversal de uma vareta combustível com falha ocasionada por PCI.

Fonte: ROY e SAH, 1985.

Já o processo de liberação térmica de gases de fissão envolve, principalmente, os gases xenônio e criptônio produzido durante o processo de fissão do combustível nuclear. Como esses gases possuem baixa solubilidade no $\mathrm{UO}_{2}$, depois de um período relativamente curto de irradiação, uma quantidade relativamente grande de gás de fisssão é gerada dentro dos grãos do combustível. As bolhas de gás de fissão geradas no interior dos grãos do combustível (intragranulares) permanecem pequenas, com dimensões menores que $30 \mathrm{~nm}$ (JERNKVIST e MASSIH, 2004). Estudos tem mostrado que as bolhas intragranulares são destruídas pelo processo de resolução induzida por irradiação, fazendo com que o gás produzido no interior do grão migre para os contornos dos grãos. No entanto, nos contornos dos grãos, a abundância de espaços podem fazer com que as bolhas cresçam e atinjam tamanhos maiores. Quando essas bolhas se interligam, elas formam uma rede de 
túneis, através do qual uma fração de produtos de fissão gasosos é liberado para o volume livre da vareta de combustível, aumentando assim sua pressão interna (JERNKVIST e MASSIH, 2004). O processo térmico de liberação de gás de fissão tem uma influência relativamente pequena em baixas queimas, porém acarreta um aumento significativo na quantidade de gás de fissão liberado quando queimas superiores a $45 \mathrm{MWd} / \mathrm{kgU}$ são atingidas. Neste ponto, ocorre o início da formação da "região escura" na pastilha combustível, região esta que é caracterizada pela interconexão das bolhas intragranulares.

\subsubsection{Fluência do combustível devido à irradiação.}

De acordo com (OLANDER, 1976), as taxas de fluência no $\mathrm{UO}_{2}$ são proporcionais às tensões e à taxa de fissão aplicadas à pastilha combustível. No que se refere à irradiação, a taxa de fluência da pastilha combustível de $\mathrm{UO}_{2}$ é afetada de duas maneiras distintas (FROST, 1982):

i. Em altas temperaturas, a taxa de fluência é maior do que a observada na ausência de radiação, porém exibe a mesma dependência com relação à temperatura. Este fenômeno é denominado fluência acentuada por fissão. Sob condições de irradiação, a fluência em altas temperaturas e sob baixas tensões tem suas taxas aumentadas em um fator de aproximadamente quatro vezes;

ii. Sob condições de baixas temperaturas, nas quais a fluência térmica pode ser desprezada, ocorre a manifestação de uma fluência independente da temperatura. Esta fluência atérmica ocorre unicamente devido à irradiação e é chamada de fluência induzida pela irradiação.

Esses efeitos são ocasionados por dois mecanismos ativados termicamente (TERREMOTO, 2012):

i. Em média temperaturas e sob a ação de tensões relativamente baixas, ocorre um aumento da fluência ocasionado por espécies que se difundem mais lentamente entre as fontes e sorvedouros de defeitos pontuais constituídos pelos contornos de grão;

ii. Sob a ação de elevadas temperaturas e tensões, ocorre um aumento da fluência ocasionado pelo deslizamento de discordâncias, que causa a travessia de obstáculos por escalagem e, consequentemente, por difusão. 


\subsubsection{Comportamento sob irradiação do revestimento de Zircaloy-4.}

Durante o projeto de uma vareta combustível, uma das maiores preocupações é evitar que ocorram perfurações no revestimento. $\mathrm{O}$ aparecimento dessas perfurações pode causar danos que inutilizem todo o elemento combustível, além de contaminar o fluído refrigerante com material radioativo. Tais perfurações, em geral, são decorrentes da corrosão e de rupturas mecânicas, ou ainda, de uma combinação desses dois efeitos.

Atualmente, o material mais utilizado como revestimento de varetas combustíveis para reatores de água pressurizada (PWR) é o Zircaloy-4, porém este vem sendo gradativamente substituído por ligas mais recentes como o ZIRLO e M5. Algumas características que tornam este material adequado para tal aplicação são sua baixa seção de absorção de nêutrons térmicos e suas boas características mecânicas e de resistência à corrosão quando submetido às condições normais de operação em um reator nuclear, ou seja, sob condições de irradiação, corrosão e com carregamentos térmicos e mecânicos (PICKMAN, 1972).

\subsubsection{Efeito da irradiação nas propriedades mecânicas do Zircaloy-4.}

Durante a irradiação por nêutrons no interior do núcleo de um reator nuclear, ocorrem diversas alterações nas propriedades mecânicas do Zircaloy-4. Essas alterações decorrem do fato de que, assim como em outros metais, o Zircaloy-4 é altamente influenciado por defeitos em sua rede cristalina causados pelo bombardeamento de nêutrons rápidos. Esse bombardeamento acarreta na formação de defeitos pontuais, vacâncias, interstíciais, discordâncias e aglomerados de defeitos (HANNERS e VESTERLUND, 1975). A intensidade da formação desses defeitos depende da temperatura, fluência de nêutrons e da composição química do revestimento.

Um dos efeitos mais pronunciados nas propriedades mecânicas do Zircaloy-4 ocasionados pela irradiação diz respeito às alterações nas propriedades de tração. Estudos realizados por PICKMAN (1972) mostram que ocorre um aumento significativo na tensão de escoamento e na resistência à tração e redução do alongamento, como pode ser observado nas curvas exibidas na Figura 2.10. 


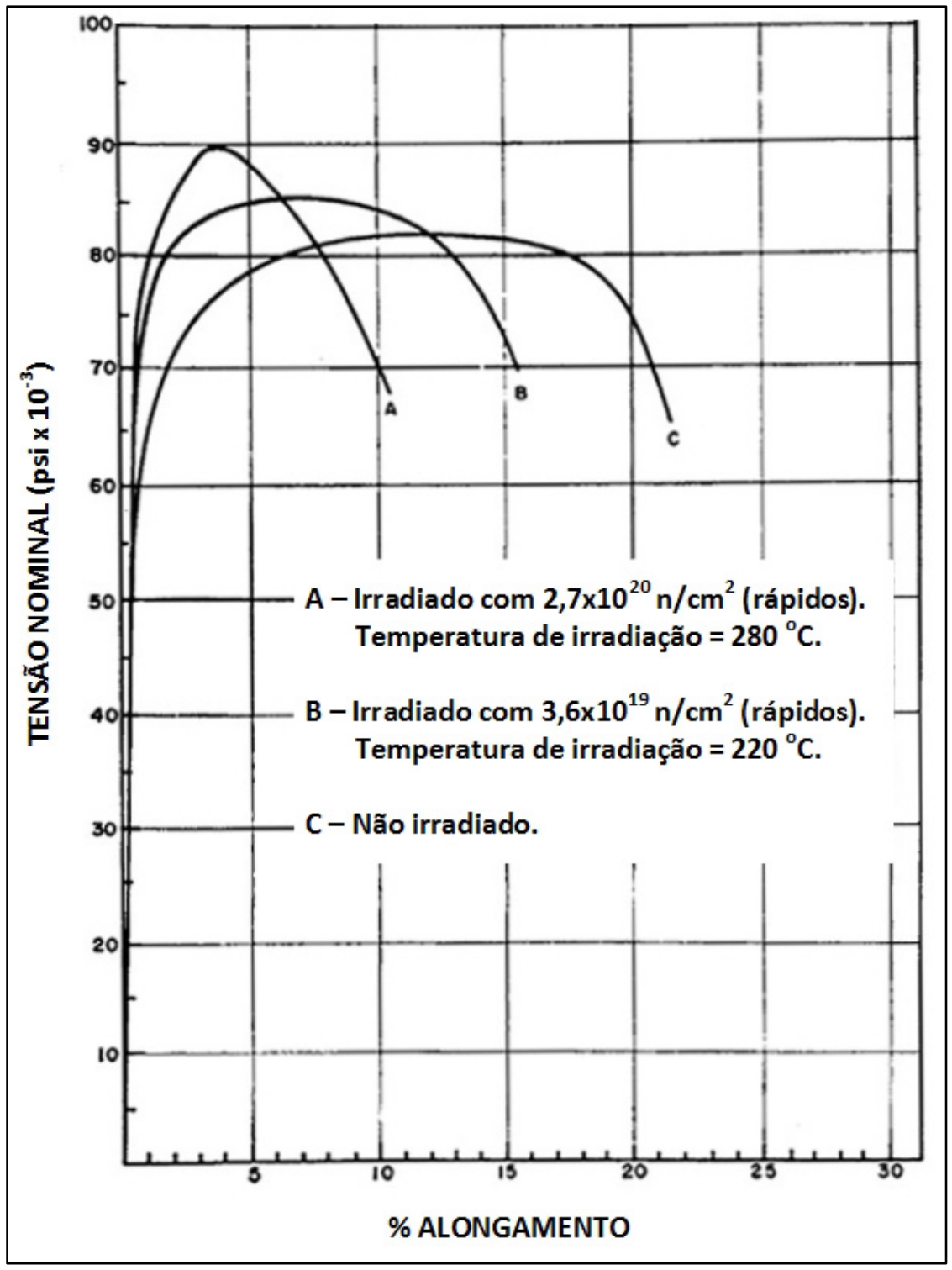

Figura 2.10 - Efeito da irradiação por nêutrons nas propriedades de Tração do Zircaloy.

Fonte: PICKMAN, 1972.

\subsubsection{Efeito de irradiação na fluência do Zircaloy-4.}

De acordo com LICKMAN (1972), a irradiação tem um efeito pronunciado sobre as propriedades de fluência no Zircaloy-4. Experimentos realizados mostraram que os efeitos mais significativos são: (1) a taxa de deformação é aumentada substancialmente, muitas vezes por uma ordem de grandeza; (2) após longos períodos de operação estável, fluência secundária é observada e; (3) devido à ductilidade relativamente alta, há um longo período de tempo entre o início de fluência terciária e a ruptura. A Figura 2.11 ilustra o efeito da irradiação no comportamento da fluência do Zircaloy submetido a uma temperatura de $300{ }^{\circ} \mathrm{C}$. 


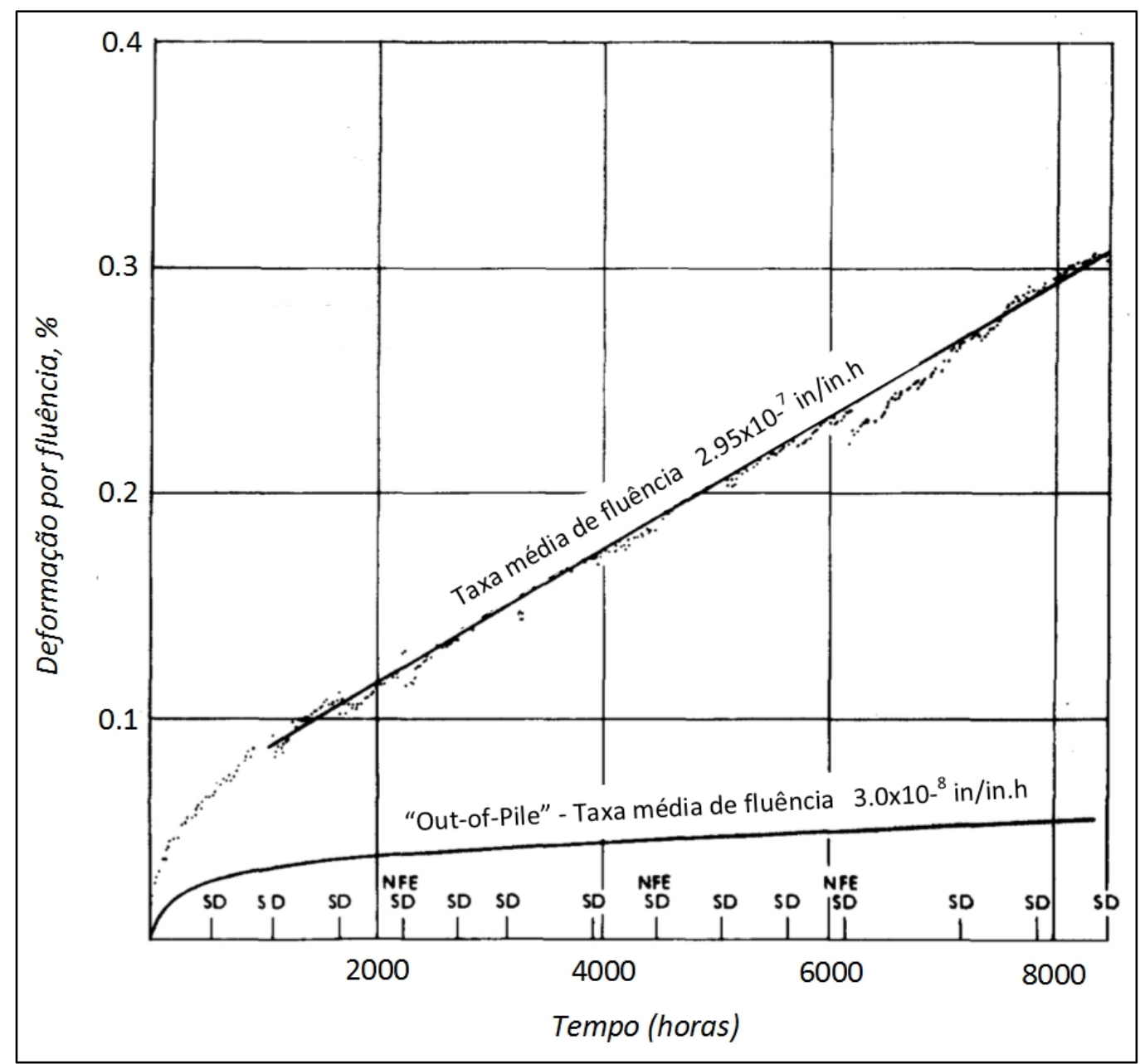

Figura 2.11 - Efeito da irradiação no comportamento da fluência do Zircaloy submetido a $300{ }^{\circ} \mathrm{C}$. Fonte: PICKMAN, 1972.

Em condições normais, o aumento da fluência do Zircaloy-4 sob irradiação não traz maiores consequências à operação da vareta combustível, sendo até um fator benéfico, pois causa relaxação de tensões no revestimento. Entretanto, se atingir valores elevados, pode ocasionar deformações inaceitáveis, as quais podem comprometer o desempenho da vareta combustível (TERREMOTO, 2012).

\subsubsection{Crescimento devido à irradiação do Zircaloy-4.}

O crescimento devido à irradiação do Zircaloy-4 é definido como uma alteração dimensional, a qual ocorre durante o processo de irradiação do revestimento por nêutrons rápidos (PARRY, 1984). O crescimento do Zircaloy-4, no intervalo de temperaturas de $612{ }^{\circ} \mathrm{C}$ a $889{ }^{\circ} \mathrm{C}$, é dependente da temperatura de irradiação, taxa de nêutrons rápidos, textura cristalográfica. No Zircaloy-4 trabalhado à frio, o crescimento é fortemente 
dependente de altos fluxos de irradiação $\left(>4,0 \times 10^{25}\right.$ nêutrons $\left./ \mathrm{m}^{2}\right)$. Já o Zircaloy-4 recozido exibe uma alta taxa de crescimento inicial, a qual é rapidamente atenuada com o aumento da dose de irradiação.

Interpretações do comportamento observado no crescimento do Zircaloy-4 tem sido postuladas em função dos danos microestruturais causados pela irradiação por nêutrons rápidos nas ligas de Zircônio. Essas interpretações associam o crescimento a deslocamentos na rede cristalina do Zircaloy-4, os quais permitem que as vacâncias migrem aos contornos de grãos, colapsando, de modo a formar loops de vacâncias randomicamente orientadas, ou que permaneçam na rede cristalina por possuírem baixa mobilidade, ou ainda que sejam capturadas por partículas de impurezas (PARRY, 1984).

\subsubsection{Corrosão do revestimento e absorção de hidrogênio pelo Zircaloy-4.}

A corrosão, juntamente com absorção de hidrogénio na matriz metálica de zircônio que acompanha o processo de corrosão, são de interesse primordial quando se considera o desempenho da vareta combustível de um reator de água leve pressurizada PWR. Para esses reatores, existe um limite prático com relação à corrosão que corresponde a uma espessura de óxido da ordem de $100 \mu \mathrm{m}$, que está associado com a quantidade crítica de absorção de hidrogênio pelo revestimento de Zircaloy-4 (ADAMSON et al., 2007).

A corrosão de ligas de zircônio é um processo complexo, eletroquimicamente conduzido, e afetado pela microestrutura e microquímica da superfície da liga. O tipo de óxido que se formam na superfície do revestimento durante a operação da vareta combustível pode ser classificado em várias categorias. Os tipos de corrosão observadas em revestimentos de Zircaloy-4 operando em PWR são os seguintes: corrosão uniforme, corrosão escura e corrosão relacionada com a incrustação.

Também é de importância o fato de que o Zircaloy se oxida na presença de vapor, e forma zircônia e gás hidrogênio, de acordo com a seguinte reação exotérmica:

$$
\mathrm{Zr}+2 \mathrm{H}_{2} \mathrm{O} \rightarrow \mathrm{ZrO}_{2}+2 \mathrm{H}_{2} \quad \Delta \mathrm{H}=-586 \mathrm{~kJ} / \mathrm{mole}
$$

Em termos de segurança, as principais consequências da oxidação do Zircaloy-4 incluem alterações nas propriedades mecânicas de revestimento, devido à formação de zircônia e absorção de oxigênio (e possivelmente de hidrogênio) no metal, além da libertação de hidrogênio gasoso e da geração de calor adicional, visto que a reação é exotérmica (GRANDJEAN e HACHE, 2008). 


\subsection{Comportamento da Vareta Combustível sob Regimes de Alta Queima.}

Atualmente, grande esforço vem sendo realizado com a finalidade de prolongar o tempo de permanência dos elementos combustíveis no interior do núcleo de reatores nucleares objetivando aumentar a densidade de energia liberada, normalmente denominada como queima ou burnup. Os benefícios advindos deste maior aproveitamento do combustível nuclear são os seguintes (ADAMSON et al., 2003):

- Econômicos (menor custo do ciclo do combustível);

- Possibilidade de longos ciclos (menor manipulação do combustível; menores doses de radiação);

- Melhor utilização de recursos naturais (diminuição da quantidade de urânio utilizada e, consequentemente, dos conjuntos de combustível por unidade de energia produzida);

- O aumento da margem para os limites de capacidade de armazenamento do combustível utilizado na planta;

- Eventual diminuição dos custos de transporte e armazenamento fora da planta.

No capítulo anterior foram analisados, de maneira resumida, os principais fenômenos que ocorrem na pastilha combustível de $\mathrm{UO}_{2}$ e no revestimento de Zircaloy-4 quando submetidos à irradiação. Entretanto, quando o combustível é submetido a longos tempos de operação no núcleo de um reator nuclear, implicando em condições de alta queima ( $>45 \mathrm{MWd} / \mathrm{kgU}$ ), diversos fenômenos são significativamente acentuados e se tornam fatores limitadores de vida para as varetas combustíveis.

Neste capítulo, serão analisados os fenômenos que são potencializados pelas condições de alta queima e seus respectivos efeitos como fatores limitantes de vida da vareta combustível.

\subsubsection{Efeito das Condições de Alta Queima na Pastilha Combustível de $\mathrm{UO}_{2}$.}

No que se refere à pastilha combustível, três fenômenos são significativamente influenciados pelas condições de alta queima e, consequentemente, considerados como fatores limitantes de vida da vareta combustível: (1) reestruturação do combustível; (2) liberação dos gases de fissão e; (3) degradação da condutividade térmica (JERNKVIST e MASSIH, 2004). 


\subsubsection{Efeito da Alta Queima na Reestruturação do Combustível.}

A microestrutura da pastilha combustível de $\mathrm{UO}_{2}$ é bastante afetada quando submetida a regimes de alta queima. Lassmann (LASSMANN et al., 1995) utiliza o termo "estrutura de alto queima" (high-burnup structure) para referenciar a região externa do combustível que sofre um grave dano estrutural, dano este decorrente do fato de que nesta região da pastilha combustível a queima local é reforçada pelo acúmulo de defeitos de irradiação e pela geração de plutônio (JERNKVIST e MASSIH, 2004), que causa um aumento da queima no local. Acima de um limite de queima de 60-70 $\mathrm{MWd} / \mathrm{kgU}$, são observadas acentuadas mudanças microestruturais envolvendo a perda da estrutura de grãos opticamente definível (subdivisão de grãos em uma escala muito fina), aumento da porosidade e depleção dos gases de fissão presentes nesta região. Esta região é comumente denominada zona de efeito de borda (rim zone structure) e atinge uma faixa de aproximadamente $200 \mu \mathrm{m}$ de espessura na região externa da pastilha combustível, em condições de queima de cerca de $60 \mathrm{MWd} / \mathrm{kgU}$ (TERREMOTO, 2012).

A Figura 2.12 apresenta curvas que ilustram o crescimento da zona de reestruturação (rim zone) em função do aumento da queima e a Figura 2.13 mostra a formação e o crescimento da zona de reestruturação também em função do aumento da queima.

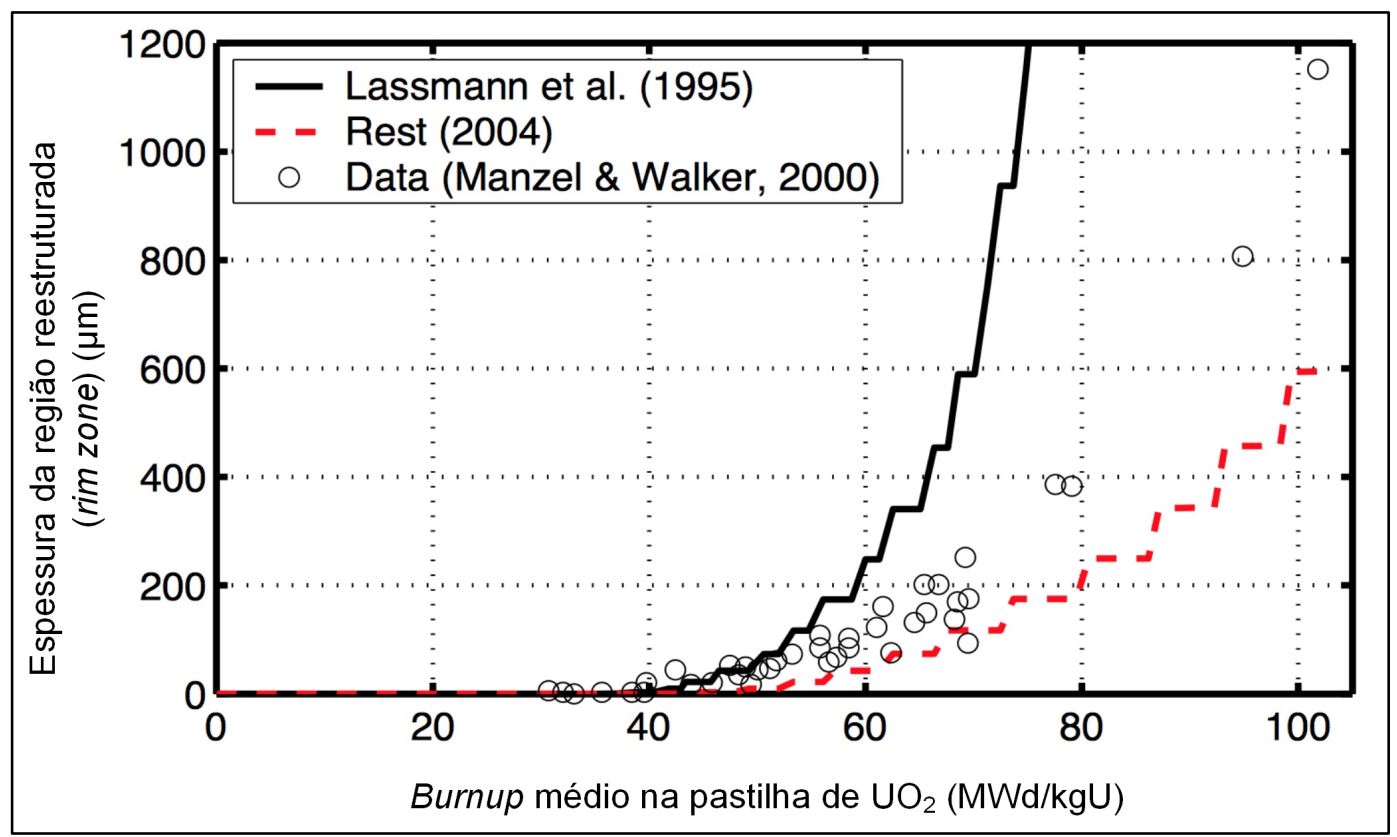

Figura 2.12 - Variação da espessura da zona de reestruturação (rim zone) para uma pastilha de $\mathrm{UO}_{2}$. Dados obtidos através de cálculos (LASSMAN et al., 1995) e (REST, 2004) e por meio de de microscopia eletrônica (MANZEL e WALKER, 2000).

Fonte: JERNKVIST e MASSIH, 2004. 


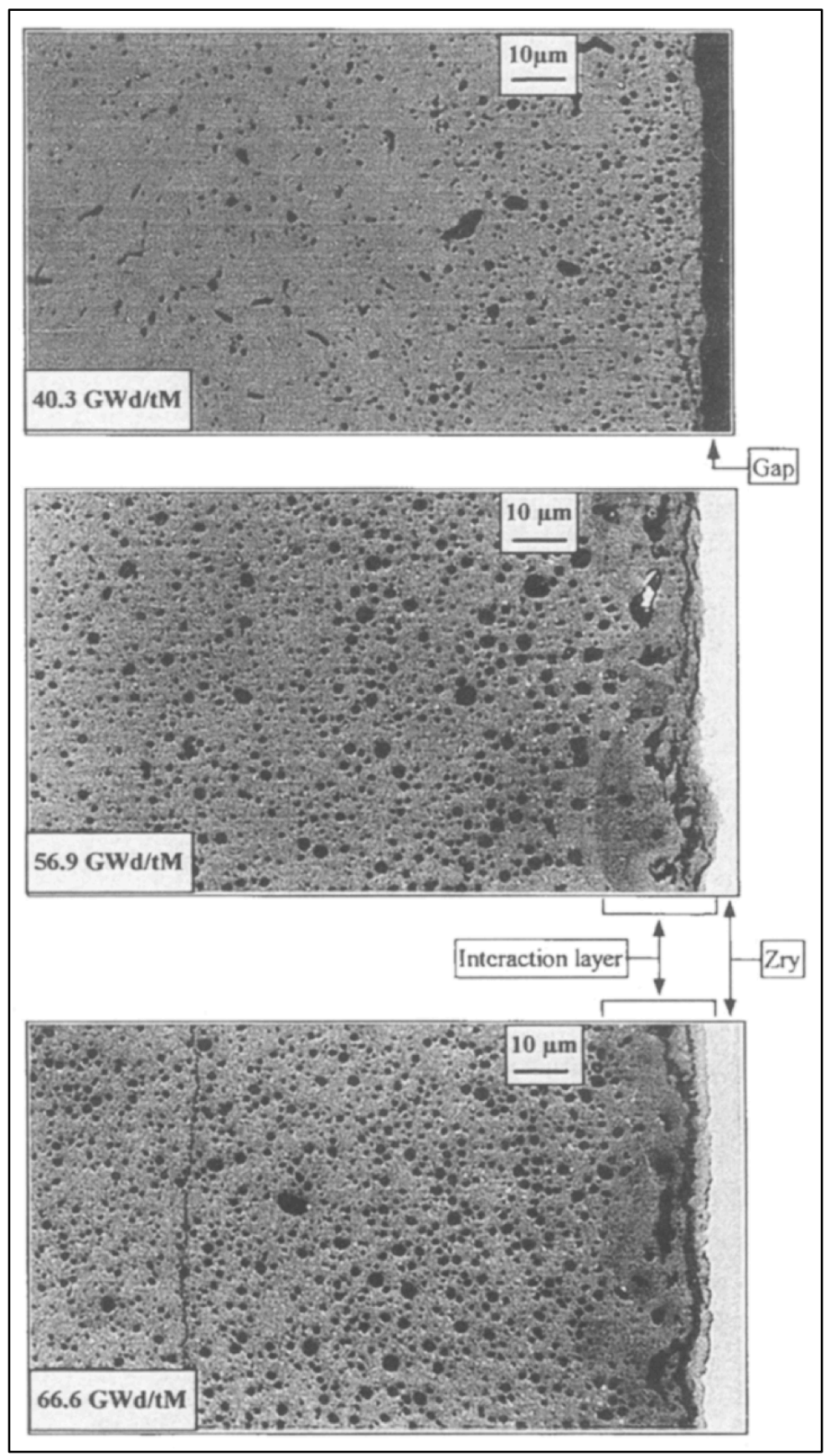

Figura 2.13 - Micrografia óptica mostrando a região periférica de uma pastilha combustível de reator PWR com diferentes queimas. A formação e o crescimento da zona de reestruturação (rim zone) é claramente visível.

Fonte: MATZKE e SPINO, 1997.

\subsubsection{Efeito da Alta Queima na Liberação de Gases de Fissão.}

De acordo com JERNKVIST e MASSIH (2002), todos os mecanismos térmicos e atérmicos de liberação de gases de fissão são afetados devido às mudanças que ocorrem nas propriedades da pastilha combustível de $\mathrm{UO}_{2}$ em função do aumento da queima. 
Entretanto, atualmente, não existe um consenso relativo à forma de como a liberação de gases de fissão é reforçada na ocorrência de altos regimes de queima.

Um dos primeiros grandes programas experimentais voltados para o estudo da liberação de gases de fissão sob regime de alta queima em combustíveis de reatores de água leve pressurizada (LWR) foi realizado pelo Programa dos Efeitos de Alta Queima (HBEP - High Burnup Effects Program), no qual foram analisadas a liberação de gases de fissão em um total de 82 varetas combustíveis, com queimas médias na faixa de 22 a 69 $\mathrm{MWd} / \mathrm{kgU}$ (BARNER et al., 1993). Os resultados obtidos mostraram que pode ser esperado um aumento na liberação de gases de fissão fracionada de aproximadamente 4\% em uma queima média de $80 \mathrm{MWd} / \mathrm{kgU}$.

Resultados obtidos em diversos experimentos (JERNKVIST et al., 2002) indicam que ocorre um aumento significativo na liberação atérmica de gases de fissão quando queimas superiores a $40-42 \mathrm{MWd} / \mathrm{kgU}$ são atingidas. Este comportamento pode ser observado nas curvas fornecidas na Figura 2.14. Nesta figura se encontram plotadas curvas referentes a dados experimentais obtidos através da irradiação de varetas combustíveis típicas de reatores LWR com resultados obtidos por meio de simulação computacional realizada com o programa FRAPCON-3.

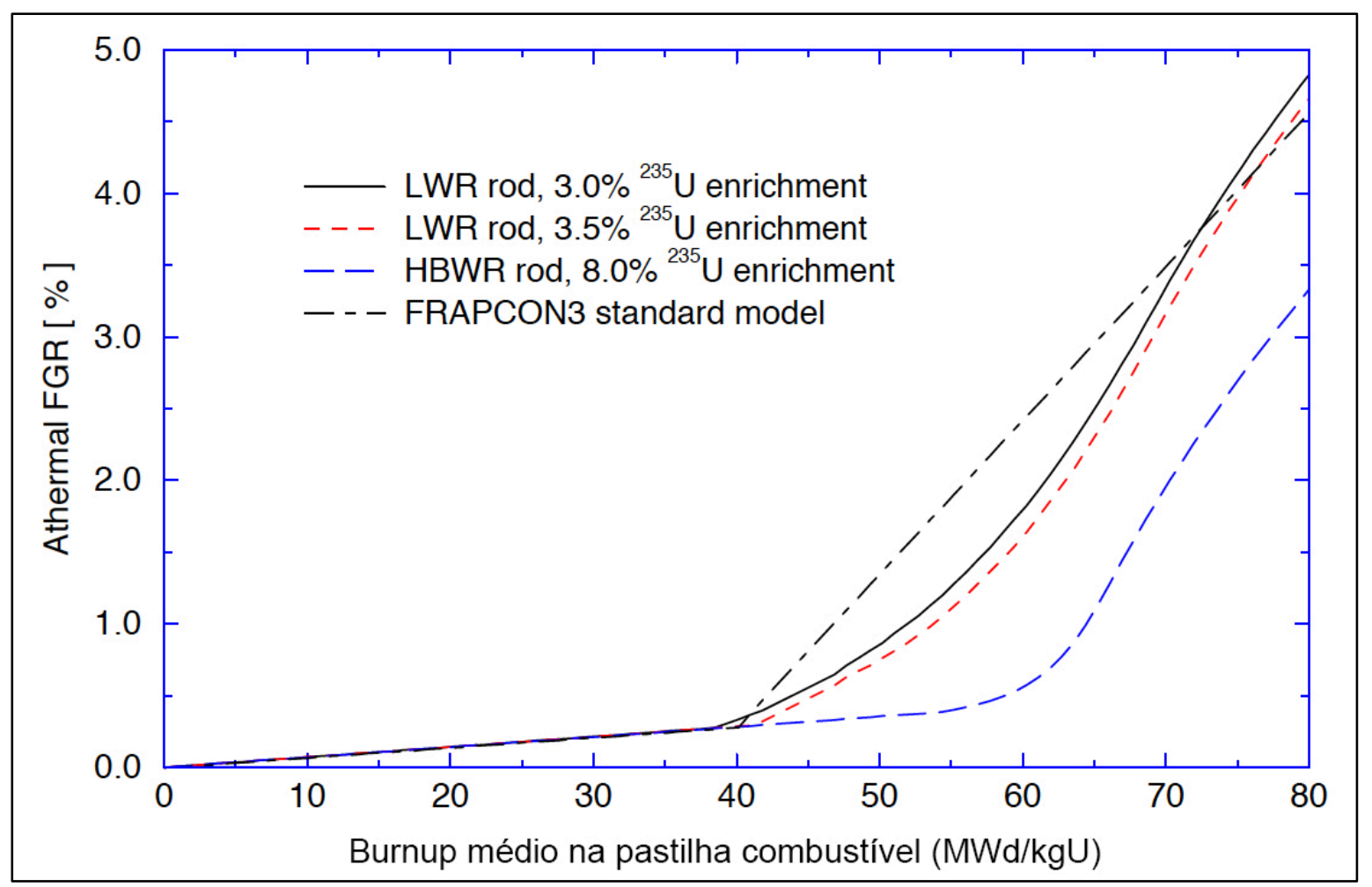

Figura 2.14 - Liberação atérmica de gás de fissão (FGR) em função da queima.

Fonte: JERNKVIST, MASSIH e BETOU, 2002. 
Outro efeito que contribui com a liberação de gases de fissão em condições de alta queima é o que se refere à criação da zona de reestruturação (rim zone structure) do combustível (JERNKVIST e MASSIH, 2004). Esta zona possui potencial para acentuar a liberação de gases devido ao fato de que quando ocorre a recristalização dos grãos originais do combustível, as bolhas intergranulares são expurgadas para fora da matriz do combustível e os novos grãos encontram-se livres das bolhas de pequeno porte. Durante este processo uma parte do gás pode escapar para o volume vazio da vareta combustível.

\subsubsection{Efeito da Alta Queima na Condutividade Térmica do $\mathrm{UO}_{2}$.}

A condutividade térmica do $\mathrm{UO}_{2}$ é um parâmetro que influencia sensivelmente o comportamento térmico da pastilha combustível durante a operação no núcleo do reator. Atualmente, os modelos mais aceitos para descrever o comportamento da condutividade térmica do $\mathrm{UO}_{2}$ são baseados em correlações empíricas, que levam em consideração parâmetros como a variação da temperatura do combustível, a queima e a porosidade.

Dentre os estudos realizados para a determinação da condutividade térmica do $\mathrm{UO}_{2}$ destacam-se os trabalhos de KINOSHITA et al. (2004) e OHIRA e ITAGAKI (1997), sendo que este último trabalho fornece o modelo utilizado para a determinação da condutividade térmica do $\mathrm{UO}_{2}$ pelo código computacional FRAPCON-3. A Figura 2.15 apresenta uma comparação da condutividade térmica determinada pelos modelos de KINOSHITA et al. e OHIRA e ITAGAKI. Como pode ser observado nesta figura, os modelos fornecem comportamentos semelhantes para a condutividade térmica para combustível com queima até $80 \mathrm{MWd} / \mathrm{kgU}$, porém com uma discrepância significativa na faixa de $50 \mathrm{MWd} / \mathrm{tU}$. Além disso, deve-se ressaltar que nesta figura, as condutividades térmicas do $\mathrm{UO}_{2}$ são plotadas para uma porosidade do combustível fixa em $5 \%$ do volume, ou seja, a evolução da porosidade, que ocorre como consequência da reestruturação do combustível sob condições de alta queima, não é considerada nas condutividades térmicas calculadas.

Resultados obtidos em experimentos mais recentes (WALKER et al., 2006) e (RONCHI et al., 2004) indicam que, em condições de alta queima, a condutividade térmica na região externa da pastilha combustível, correspondente à região de reestruturação, é bem maior de que a condutividade térmica na região em que a reestruturação não ocorre. Dados experimentais fornecidos na Figura 2.16 mostram que, na região externa do 
combustível, a zona reestruturada provoca um aumento de aproximadamente $50 \%$ na difusividade térmica (grandeza diretamente proporcional à condutividade térmica). Esta discrepância não é considerada pelo modelo utilizado no programa FRAPCON-3.4a e decorre, provavelmente, devido à perda da porosidade na região reestruturada.

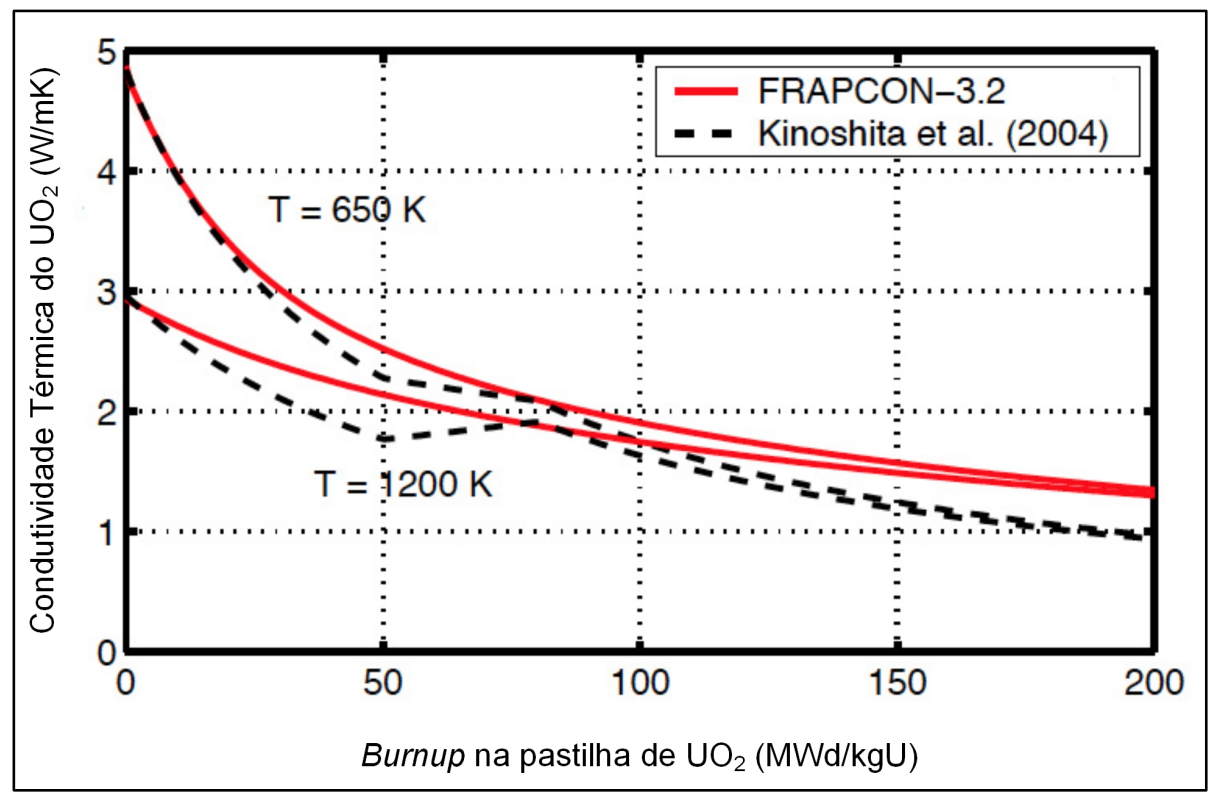

Figura 2.15 - Comparação entre os modelos de (KINOSHITA et al., 2004) e (OHIRA e ITAGAKI, 1997)/FRAPCON para a determinação da condutividade térmica do $\mathrm{UO}_{2}$.

Fonte: JERNKVIST e MASSIH, 2004.

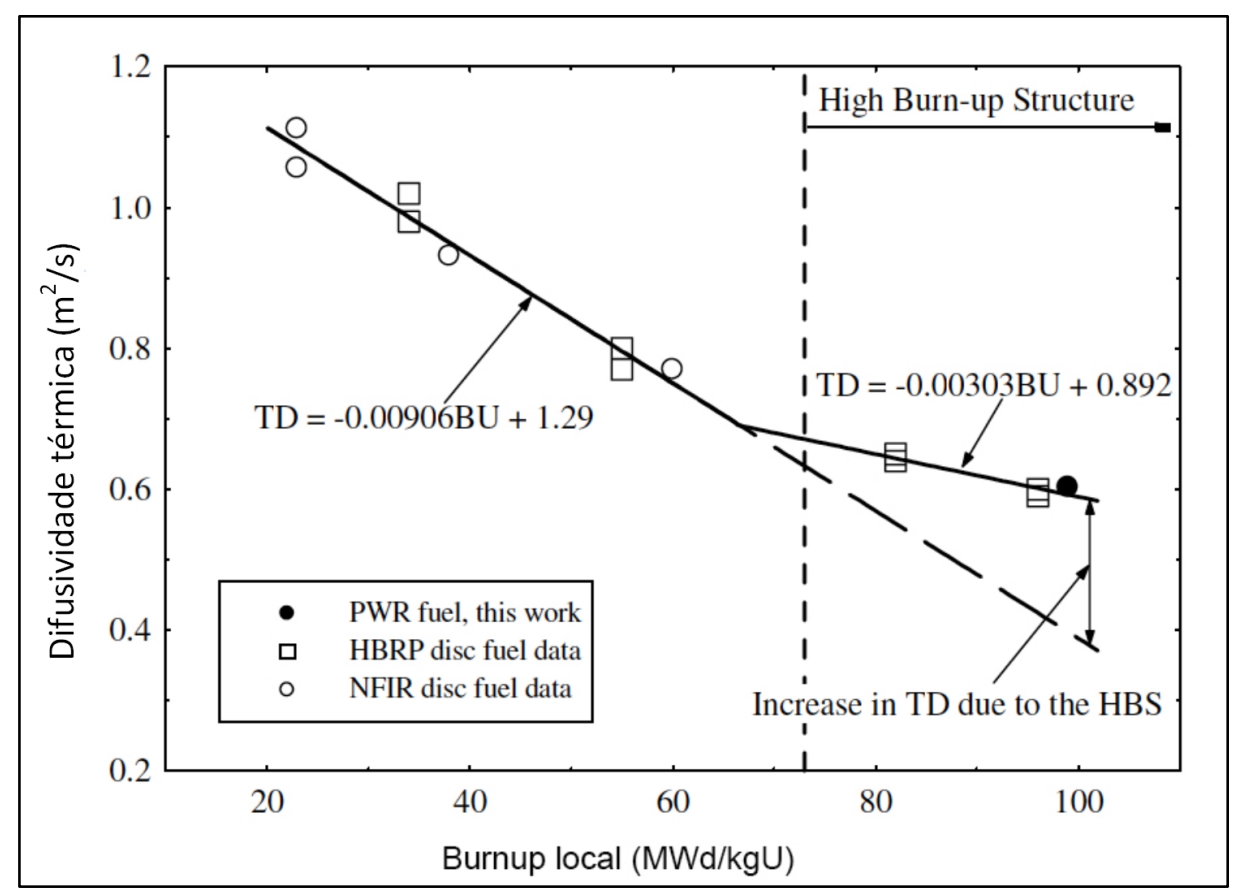

Figura 2.16 - Influência da presença da estrutura e alta queima (HBS) na difusividade térmica do $\mathrm{UO}_{2}$.

Fonte: WALKER et al., 2006. 


\subsubsection{Efeito das Condições de Alta Queima no Revestimento de Zircaloy-4.}

Com relação ao revestimento, condições de alta queima acarretam maiores níveis de corrosão, maior absorção de hidrogênio e uma maior degradação de suas propriedades mecânicas (ADAMSON et al., 2003). Adicionalmente, um efeito bastante crítico, que possui uma maior probabilidade de se manifestar em condições de alta queima é a interação mecânica entre a pastilha e o revestimento (PCMI - Pellet-Clad Mechanical Interaction).

\subsubsection{Efeito da Alta Queima na Corrosão do Revestimento pelo Refrigerante.}

Sob condições de irradiação, ocorre um aumento da taxa de corrosão do Zircaloy-4. Este aumento deve-se principalmente às alterações microestruturais ocasionadas pela irradiação, às condições termo-hidráulicas e alterações químicas do refrigerante, e ao efeito da irradiação no processo de corrosão propriamente dito (LEFEVBRE e LEMAIGNAN, 1997).

Apesar de ainda ser objeto de extensos estudos, o efeito de longos períodos de permanência da vareta combustível no reator possui uma forte influência no processo de corrosão da superfície externa do revestimento, pois este processo ocorre continuamente durante todo o período de tempo em que o elemento combustível se encontra no interior do reator. A Figura 2.17 ilustra o crescimento da camada de óxido no revestimento de Zircaloy-4 em função da queima. Nesta figura é realizada uma comparação de dados experimentais com os resultados fornecidos por meio do modelo utilizado pelo código computacional FRAPCON-3.2 (JERNKVIST e MASSIH, 2004). Como pode ser observado na Figura 2.17, existe uma boa concordância dos dados experimentais com os dados obtidos através do modelo utilizado pelo código FRAPCON-3.2 até uma queima de aproximadamente $40 \mathrm{MWd} / \mathrm{kgU}$. Porém, a partir deste ponto, os dados experimentais mostram um aumento significativo da espessura da camada de óxido, situação esta que não é correspondida pelo modelo empregado pelo código.

Diversos trabalhos tem sido desenvolvidos com a finalidade de elucidar o motivo que leva à aceleração da corrosão do revestimento quando altas queimas são atingidas (KIDO et al., 1997) e (LIMBACK, 1996). Esses trabalhos sugerem que o aumento da taxa de corrosão em altas queimas pode ser explicado pela precipitação de hidretos na interface óxido-metal do revestimento, a qual perturba a coesão do material na interface. 


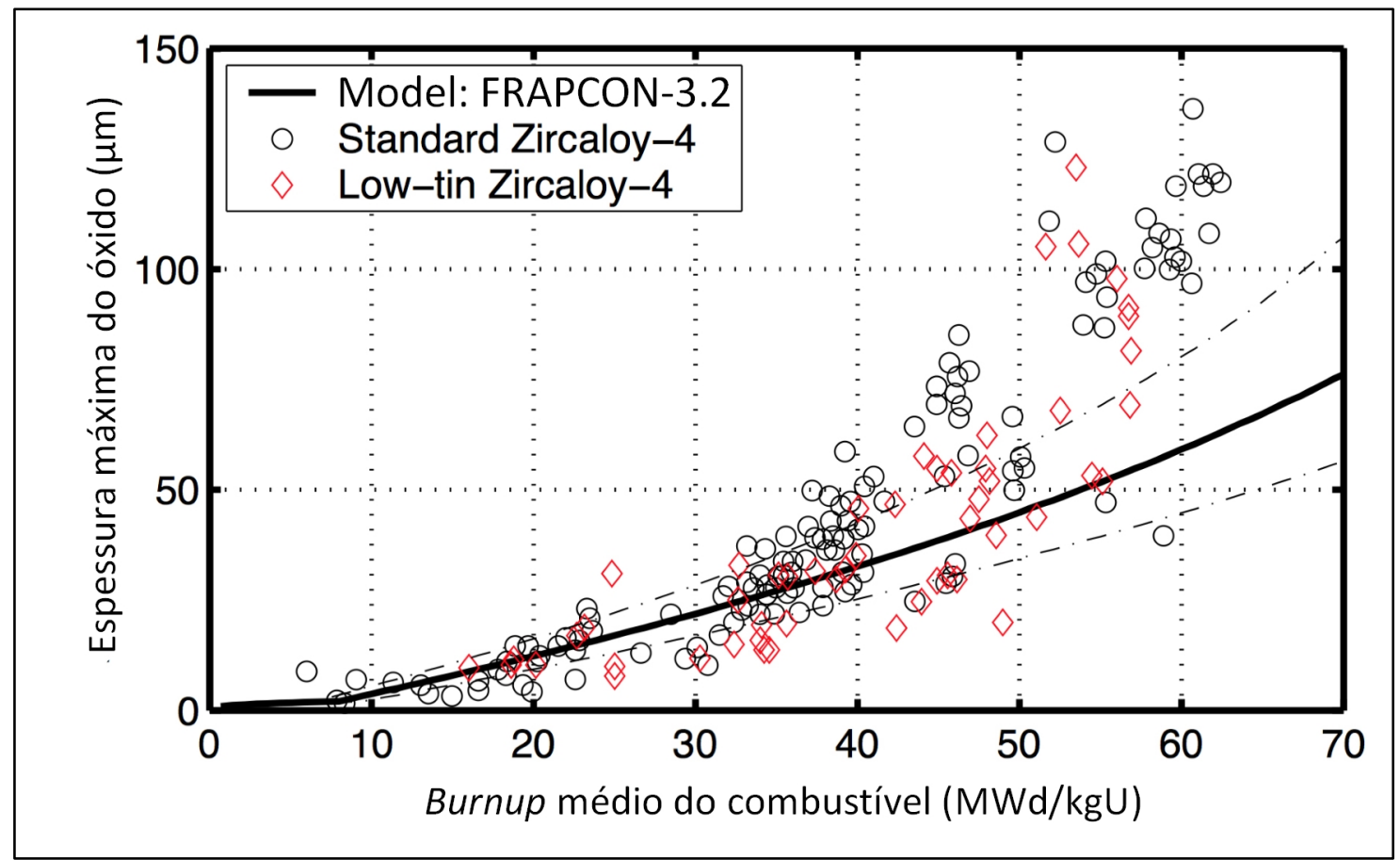

Figura 2.17 - Espessura da camada de óxido no revestimento de Zircaloy-4 em função da queima.

Fonte: JERNKVIST e MASSIH, 2004.

\subsubsection{Efeito da alta queima na hidretação do revestimento.}

Conforme mencionado no Item 2.2.2.4, maiores queimas irão resultar em uma maior corrosão do revestimento, levando a uma maior produção de hidrogênio, o qual pode ser absorvido pelo Zircaloy-4. Hidrogênio em excesso, da ordem de 100-150 ppm em peso, irão precipitar em hidretos de zircônio que podem fragilizar o material. Esta fragilização depende não somente da concentração de hidretos, mas também da distribuição e orientação desses hidretos no material. Deste modo, os seguintes pontos devem ser considerados no que se refere aos efeitos da hidretação do revestimento em condições de alta queima (RUDLING, 2007):

- O aumento da fração de hidretos reduz a ductilidade e a resistência à fratura do Zircaloy-4. Também deve ser ressaltado o fato de que o efeito da fragilização por hidretos é bastante dependente da temperatura, sendo intensificado em temperaturas mais baixas;

- A distribuição não uniforme dos hidretos reduz a ductilidade e a resistência à fratura de um modo mais intenso do que quando ocorre uma distribuição uniforme dos hidretos; 
- A intensidade da fragilização do revestimento será mais intensificada quando ocorrer a formação de hidretos orientados perpendicularmente à direção das linhas de tensões de tração presentes no revestimento.

\subsubsection{Efeito da Alta Queima nas Propriedades Mecânicas do Revestimento.}

Durante a irradiação, ocorrem alterações nas propriedades mecânicas do revestimento de Zircaloy-4. Essas alterações são causadas pelo acúmulo de danos de irradiação no material e afetam, em maior escala, as propriedades de rigidez mecânica, comportamento à fratura e fluência (HANNERZ e VESTERLUND, 1975). Entretanto, essas alterações no revestimento decorrentes de danos de irradiação saturam no início da operação, normalmente no primeiro ano de utilização da vareta combustível no núcleo do reator (JERNKVIST e MASSIH, 2004). Deste modo, as alterações das propriedades mecânicas que ocorrem no revestimento de Zircaloy-4 decorrentes da irradiação não são um problema preponderante em regimes de altas queimas. $\mathrm{O}$ efeito da corrosão da parede externa do tubo de revestimento é, em geral, um fator bem mais importante quando se estuda o comportamento do revestimento em regimes de alta queima.

Entretanto, um dos efeitos que uma alta queima pode acarretar nas propriedades mecânicas do revestimento refere-se à alteração do limite de escoamento do Zircaloy-4. Conforme mencionado no Item 2.3.2.2, a precipitação de hidretos de zircônio causa a fragilização do revestimento, fazendo com que ocorra uma redução na capacidade que este possui em absorver deformações plásticas. Além disso, a fragilização induzida por hidretação leva a uma perda da capacidade de deformação do material, causando uma redução do limite de escoamento.

\subsubsection{Interação Mecânica entre a Pastilha e o Revestimento (PCMI) em Regimes de Alta Queima.}

A interação mecânica entre a pastilha e o revestimento (PCMI - Pellet-Clad Mechanical Interaction) é uma situação na qual se estabelece um intenso contato mecânico entre a pastilha combustível e o revestimento, contato este que pode levar à ruptura do revestimento. É importante ressaltar que o efeito de PCMI ocorre sem a ação da corrosão 
sob tensão SCC (Stress Corrosion Cracking) fenômeno este que caracteriza a interação pastilha revestimento (PCI - Pellet Clad Interaction) (ADAMSON, 2006).

Em regimes de alta queima, a ocorrência deste intenso contato entre a superfície externa da pastilha e o revestimento é potencializada pela maior geração de gases de físsão que ocorre nesta condição. Esta maior geração de gases de fissão causa um maior inchamento da pastilha combustível, que favorece o contato pastilha-revestimento e pode gerar tensões de tração tangencial relativamente elevadas no revestimento. Essas tensões elevadas, associadas ao fato de que em condições de alta queima o revestimento já se encontra fragilizado pela hidretação e pela corrosão, pode levar à ocorrência de falha por PCMI. 


\section{PROGRAMA FUMEX III}

O programa experimental FUMEX, promovido pela Agência Internacional de Energia Atômica (IAEA) tem como premissa o fato de que, para se manter competitiva com relação às outras formas de geração de energia elétrica, os projetos de novas centrais nucleares necessitam ser altamente eficientes e extremamente seguros. Como consequência desta premissa, torna-se necessário possuir uma maior compreensão do desempenho do combustível nuclear e incorporar essa maior compreensão aos códigos computacionais utilizados para simular o comportamento do combustível em diversas situações operacionais.

Devido à grande diversidade de fenômenos que ocorrem durante a operação de uma vareta combustível, e da complexa inter-relação entre esses fenômenos, o processo para a validação dos códigos computacionais utilizados para predizer o comportamento das varetas combustíveis é bastante difícil de ser realizado. A Figura 3.1 ilustra o complexo inter-relacionamento entre os diversos modelos implantados nesses códigos.

Deste modo, a AIEA acompanha uma série de programas experimentais que abordam diferentes aspectos da modelagem e do comportamento do combustível nuclear em diferentes situações operacionais. Os principais objetivos desses programas experimentais são (IAEA-FUMEX-III, 2012):

- Avaliar a maturidade e a capacidade predição dos códigos utilizados para a análise do desempenho do combustível nuclear, e também fornecer suporte e incentivar a troca de informações entre países que desenvolvem ou utilizam esses códigos;

- Consolidar uma base com dados experimentais bem definidos e adequados para serem utilizados no processo de validação desses códigos;

- Transferir para os países em desenvolvimento um código maduro para a análise do desempenho do combustível nuclear, além de apoiar as equipes desses países em seus esforços para adaptar este código aos requisitos de determinados reatores, e também para fornecer orientações sobre a aplicação deste código no processo de avaliação da operação e da segurança do reator;

- Fornecer orientações para a garantia da qualidade e o licenciamento do código, e também para a aplicação do código no processo de licenciamento de combustível nuclear. 


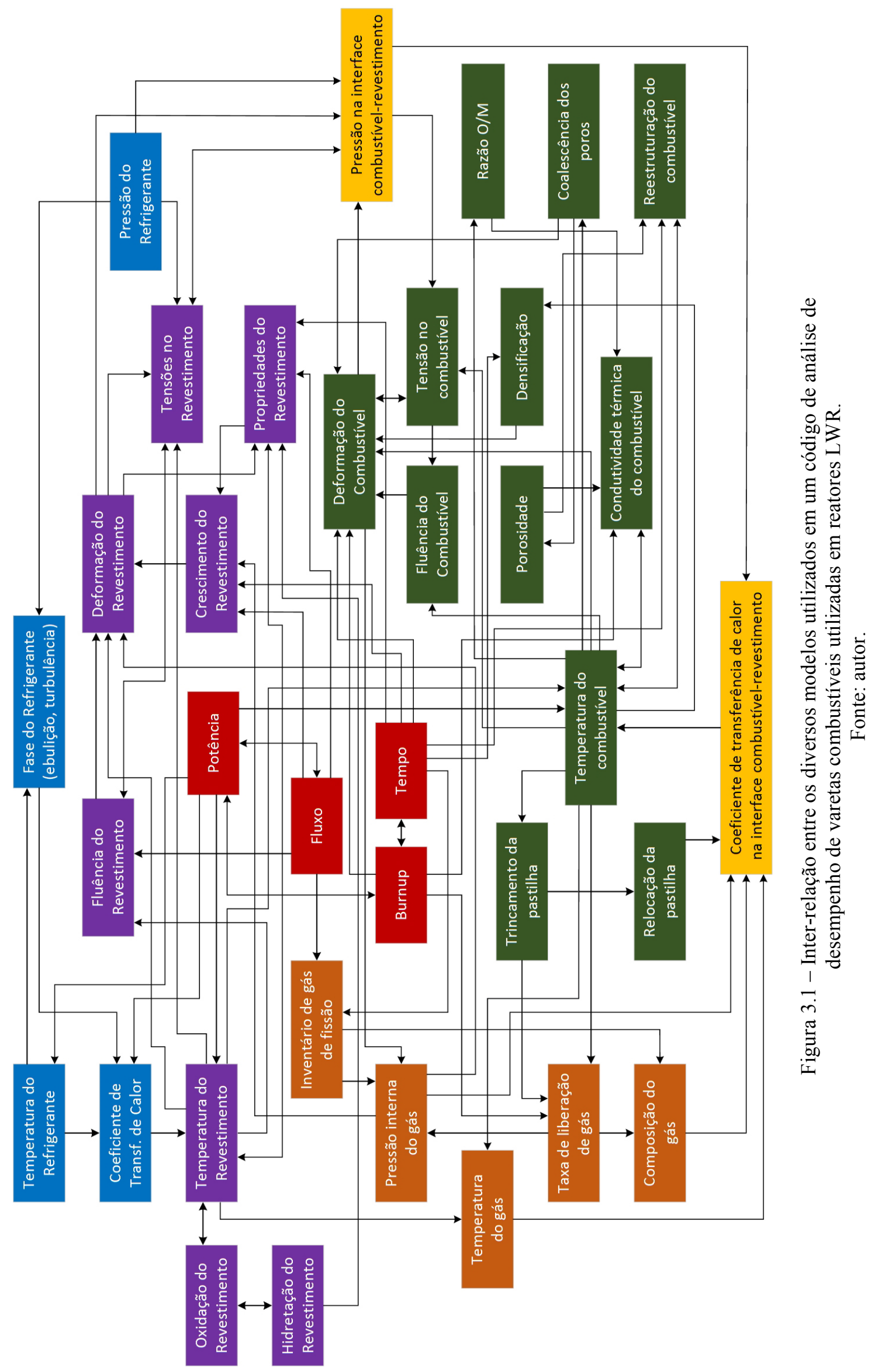


O programa FUMEX teve inicio em 1993, sendo seus resultados iniciais fornecidos no relatório "Fuel Modelling at Extended Burnup - Report of the Co-ordinated Research Programme on Fuel Modelling at Extended Burnup - FUMEX - 1993-1996". Posteriormente, em 2002, se iniciou uma segunda fase do programa, cujos resultados foram disponibilizados através do relatório "Fuel Modelling at Extended Burnup (FUMEXII) - Repost of a Coordinated Research Project 2002-2007'.

A edição mais recente deste programa experimental se encontra documentada no relatório "Improvement of Computer Codes Used for Fuel Behaviour Simulation (FUMEXIII) - Report of a Coordinated Research Project 2008-2012”. Este relatório apresenta diversos experimentos que procuram fornecer dados que tornem possível melhorar a capacidade preditiva dos códigos utilizados para a análise do desempenho do combustível em condições de regime permanente e em condições de transientes (tais como RIA e LOCA), em regimes de alta queima.

Neste trabalho é dada ênfase aos resultados fornecidos pela terceira edição deste programa, ou seja, o FUMEX III. Esta edição contou com a participação de 22 países e disponibilizou dados advindos de 24 experimentos realizado durante um período de cinco anos. A Tabela 3.1 apresenta os experimentos acompanhados pelo programa FUMEX III. Como pode ser observado nesta tabela, o foco principal do programa FUMEX III está na analise de operação do combustível nuclear sob condição de transientes, ou seja, rampas de potência e acidentes RIA e LOCA, além de estudos de processos de PCI e PCMI.

Dos experimentos disponibilizados pela base de dados FUMEX III, foram selecionados para as análises realizadas neste trabalho os seguintes casos:

- Para condições de regime estacionário, foram selecionados os experimentos:

- IFPE/US-PWR-16x16 LTA (NEA-1738/01);

○ IFPE/RISOEIII-GE7 (NEA-1493/17) com PCMI.

- Para condições de regime transiente, considerando a ocorrência de um acidente tipo RIA, foi selecionado o seguinte experimento:

○ IFPE/NSRR-FK1 (NEA-1724/01).

Esses experimentos foram selecionados por serem aqueles que melhor se adaptam aos requisitos especificados por este trabalho, ou seja, possuírem uma boa variedade de dados para comparação com as simulações a serem realizadas e fornecerem todos os dados para que possam ser criados os arquivos de entrada necessários à execução dos programas computacionais FRAPCON e FRAPTRAN. 
Tabela 3.1 - Relação dos casos disponibilizados ao final do programa FUMEX-III.

Fonte: IAEA-TECDOC-1697

\begin{tabular}{|c|c|c|c|c|c|}
\hline \multirow[b]{2}{*}{ Condição } & \multirow[b]{2}{*}{ Caso } & \multirow[b]{2}{*}{ Comentários } & \multicolumn{3}{|c|}{ Sistema } \\
\hline & & & 空 & $\sum_{3}^{n}$ & $\underbrace{\frac{\alpha}{3}}_{3}$ \\
\hline \multirow[t]{7}{*}{$\begin{array}{l}\text { Operação } \\
\text { normal }\end{array}$} & US PWR 16x16 & $\begin{array}{l}\text { Pastilhas sólidas e aneladas. Queima } \\
\text { aproximada de } 55 \mathrm{MWd} / \mathrm{kgU} \text {. }\end{array}$ & & $\mathrm{X}$ & $\mathrm{X}$ \\
\hline & Caso AREVA & $\begin{array}{l}\text { Combustível comercial. } \\
\text { Histórico até } 80 \mathrm{MWd} / \mathrm{kgU} \text { com FGR. }\end{array}$ & & $\mathrm{X}$ & $\mathrm{X}$ \\
\hline & Casos FUMEX-II & Casos para serem utilizados por recém-chegados. & & $\mathrm{X}$ & \\
\hline & Riso-3 AN2 AN3 & $\begin{array}{l}\text { Distribuição radial de produtos de fissão e FGR- } \\
\text { EOL. Queima aproximada de } 40 \mathrm{MWd} / \mathrm{kgU} \text {. }\end{array}$ & & $\mathrm{X}$ & \\
\hline & R. E. Ginna & $\begin{array}{l}\text { Pastilhas sólidas e aneladas. Queima } \\
\text { aproximada de } 55 \mathrm{MWd} / \mathrm{kgU} \text {. }\end{array}$ & & $\mathrm{X}$ & $\mathrm{X}$ \\
\hline & RO51 RO89 & $\begin{array}{l}\text { Variantes CANDU. } \\
\text { Queima até } 160 \mathrm{MWd} / \mathrm{kgU} .\end{array}$ & $\mathrm{X}$ & & \\
\hline & AECL BDL-406 & $\begin{array}{l}\text { Combustível } \mathrm{UO}_{2} \text { natural irradiado em baixas } \\
\text { potencias lineares }(30-40 \mathrm{~kW} / \mathrm{m}) \text { até queimas } \\
\text { superiores a } 450 \mathrm{MWd} / \mathrm{kgU} \text { no reator NRU. }\end{array}$ & $\mathrm{X}$ & & \\
\hline Gadolínio & $\begin{array}{l}\text { Varetas GAIN } 301 \\
\text { e } 701\end{array}$ & $\begin{array}{l}\text { Varetas dopadas com } 3 \% \text { e } 7 \% \text { de gadolínio } \\
\text { irradiadas até } 50 \mathrm{MWd} / \mathrm{kgU} \text {. }\end{array}$ & & $\mathrm{X}$ & $\mathrm{X}$ \\
\hline \multirow[t]{5}{*}{ Transientes } & IFA $535.5 / 6$ & $\begin{array}{l}\text { Vareta experimental com baixa pressão interna. } \\
\text { Queima aproximada de } 48 \mathrm{MWd} / \mathrm{kgU} \text {. }\end{array}$ & & $\mathrm{X}$ & \\
\hline & Riso-3 II5 & Rampa de potencia até $40 \mathrm{~kW} / \mathrm{m}$ em $50 \mathrm{MWd} / \mathrm{kgU}$ & & $\mathrm{X}$ & $\mathrm{X}$ \\
\hline & Vareta GAIN 701 & Vareta com $7 \%$ de gadolínio testada em rampa. & & $\mathrm{X}$ & \\
\hline & IRDMR FIO 118/119 & $\begin{array}{l}\text { Medidas de diâmetro de combustível tipo } \\
\text { CANDU em rampa. }\end{array}$ & $\mathrm{X}$ & & \\
\hline & MIR & $\begin{array}{l}\text { Combustível WWER em rampa de até } 40 \mathrm{~kW} / \mathrm{m} \\
\text { em queima de até } 60 \mathrm{MWd} / \mathrm{kgU} \text {. }\end{array}$ & & & $\mathrm{X}$ \\
\hline \multirow[t]{2}{*}{$\begin{array}{l}\text { Segmento } \\
\text { de carga }\end{array}$} & CANDU JC NR & $\begin{array}{l}\text { Feixes de combustível CANDU ( } 37 \text { elementos) } \\
\text { Testado no reator NRU. }\end{array}$ & $\mathrm{X}$ & & \\
\hline & IFA & $\begin{array}{l}\text { Queima muito elevada ( } 100 \mathrm{MWd} / \mathrm{kgU}) \text {. Testado } \\
\text { no reator Halden com problemas em alguns dados. }\end{array}$ & & $\mathrm{X}$ & $\mathrm{X}$ \\
\hline $\begin{array}{l}\text { Critério de } \\
\text { PCI }\end{array}$ & $\begin{array}{l}\text { INTER-RAMP e } \\
\text { SUPER-RAMP }\end{array}$ & $\begin{array}{l}\text { Testes com rampas em PWR e BWR. } 50 \% \text { das } \\
\text { varetas falharam durante as rampas. Predições de } \\
\text { falha por PCI requerida. }\end{array}$ & $\mathrm{X}$ & $\mathrm{X}$ & $\mathrm{X}$ \\
\hline \multirow[t]{4}{*}{ PCMI } & $\begin{array}{l}\text { Riso-2 GE-m } \\
\text { Riso-3 II-3 }\end{array}$ & $\begin{array}{l}\text { Teste de rampa de potência em varetas com baixa } \\
\text { queima (aproximadamente } 17 \mathrm{MWd} / \mathrm{kgU} \text { ). }\end{array}$ & $\mathrm{X}$ & $\mathrm{X}$ & \\
\hline & Riso-3 GE7 & $\begin{array}{l}\text { Teste de rampa em } 35 \mathrm{~kW} / \mathrm{m} \text { até } 42 \mathrm{MWd} / \mathrm{kgU} \text {. } \\
\text { Bons dados de ridging. }\end{array}$ & & $\mathrm{X}$ & $\mathrm{X}$ \\
\hline & OSIRIS H09 (J12) & Medidas do diâmetro antes e depois da rampa & & $\mathrm{X}$ & \\
\hline & CNEA BU15 & Rampa em combustível MOX. & $\mathrm{X}$ & & \\
\hline RIA & $\begin{array}{l}\text { BWR PWR RIA } \\
\text { FK1 e FK2 }\end{array}$ & $\begin{array}{l}\text { Testes com dois pulsos de irradiação; intactos em } \\
544 \text { e } 293 \mathrm{~J} / \mathrm{g}(130 \mathrm{e} 70 \mathrm{cal} / \mathrm{g}) \text {. }\end{array}$ & & $\mathrm{X}$ & \\
\hline
\end{tabular}


Tabela 3.1 - Relação dos casos disponibilizados ao final do programa FUMEX-III (continuação).

Fonte: IAEA-TECDOC-1697

\begin{tabular}{|c|c|c|c|c|c|}
\hline \multirow[b]{2}{*}{ Condição } & \multirow[b]{2}{*}{ Caso } & \multirow[b]{2}{*}{ Comentários } & \multicolumn{3}{|c|}{ Sistema } \\
\hline & & & 号 & 茪 & 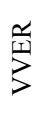 \\
\hline \multirow[t]{2}{*}{ LOCA } & IFA $650.1-2$ & Envolvendo estudos de LOCA no reator Halden & & $\mathrm{X}$ & $\mathrm{X}$ \\
\hline & FIO 131 & LOCA em combustíveis tipo CANDU. & $\mathrm{X}$ & & \\
\hline \multirow[t]{2}{*}{ MOX } & IFA 629 & Combustível MOX refabricado; irradiado em Halden. & & $\mathrm{X}$ & \\
\hline & PRIMO & $\begin{array}{l}\text { Combustível MIMAS MOX irradiado à queima de } \\
30,1 \mathrm{MWd} / \mathrm{kgU} \text { e então testado em rampa. }\end{array}$ & & $\mathrm{X}$ & \\
\hline
\end{tabular}




\section{ANÁlise dOS PROGRAMAS COMPUTACIONAIS FRAPCON-3.4A E FRAPTRAN-1.4.}

Neste capítulo são apresentadas as características estruturais e funcionais dos programas computacionais FRAPCON-3.4a e FRAPTRAN-1.4a. Esses programas são utilizados na análise do desempenho de varetas combustíveis de reatores de água leve (LWR) operando em regime estacionário (FRAPCON) e em condições de transiente, incluindo acidentes do tipo RIA e LOCA (FRAPTRAN).

\subsection{Características do Programa Computacional FRAPCON-3.4a}

O programa computacional FRAPCON-3.4a é uma ferramenta analítica que determina o comportamento de varetas combustíveis para reatores de água leve (LWR) operando em condições nas quais as variações do sistema ocorram de forma suficientemente lenta para que o termo estacionário possa ser utilizado. Essas condições envolvem a operação típica de um reator nuclear, com geração de potência constante em longos períodos de tempo ou em situações em que ocorram pequenas rampas de potência ao longo do tempo (GEELHOOD; LUSCHER; BEYER, 2011).

O programa FRAPCON-3.4a analisa, no decorrer do tempo, a influência dos fenômenos mais significativos que afetam o desempenho de uma vareta combustível durante a irradiação. Essas análises incluem:

- Temperaturas no combustível e no revestimento;

- Inchamento e densificação do combustível devido à irradiação;

- Liberação de gases de fissão;

- Pressão interna da vareta combustível;

- Tensões no revestimento;

- Oxidação do revestimento.

Adicionalmente, o FRAPCON-3.4a fornece as condições iniciais utilizadas para a geração do arquivo de entrada de dados do programa computacional FRAPTRAN, utilizado para a análise de transientes em varetas combustíveis.

O código FRAPCON-3.4a é constituído por quatro grandes módulos funcionais: (1) módulo de rotinas para a determinação das propriedades físicas dos materiais, (2) módulo para análise do comportamento térmico da pastilha combustível e do revestimento, (3) 
módulo para análise do comportamento mecânico do revestimento e (4) módulo para determinação de liberação de gases de físsão e cálculo da pressão interna da vareta combustível.

O módulo de propriedades físicas dos materiais tem por finalidade fornecer os dados necessários para as analises realizadas pelos outros três módulos que constituem o código. Esses dados estão relacionados às principais características físicas, químicas e comportamentais dos materiais que constituem a vareta combustível.

Com os dados fornecidos pelo módulo de propriedades físicas dos materiais, os módulos de análise do comportamento térmico da pastilha combustível e do revestimento, de análise do comportamento mecânico do revestimento e de determinação de liberação de gases de fissão iniciam um processo de interação, o qual fornece resultados que permitem caracterizar o desempenho de uma vareta combustível sob condições de operação em regime estacionário. Este processo é ilustrado, de forma simplificada, na Figura 4.1.

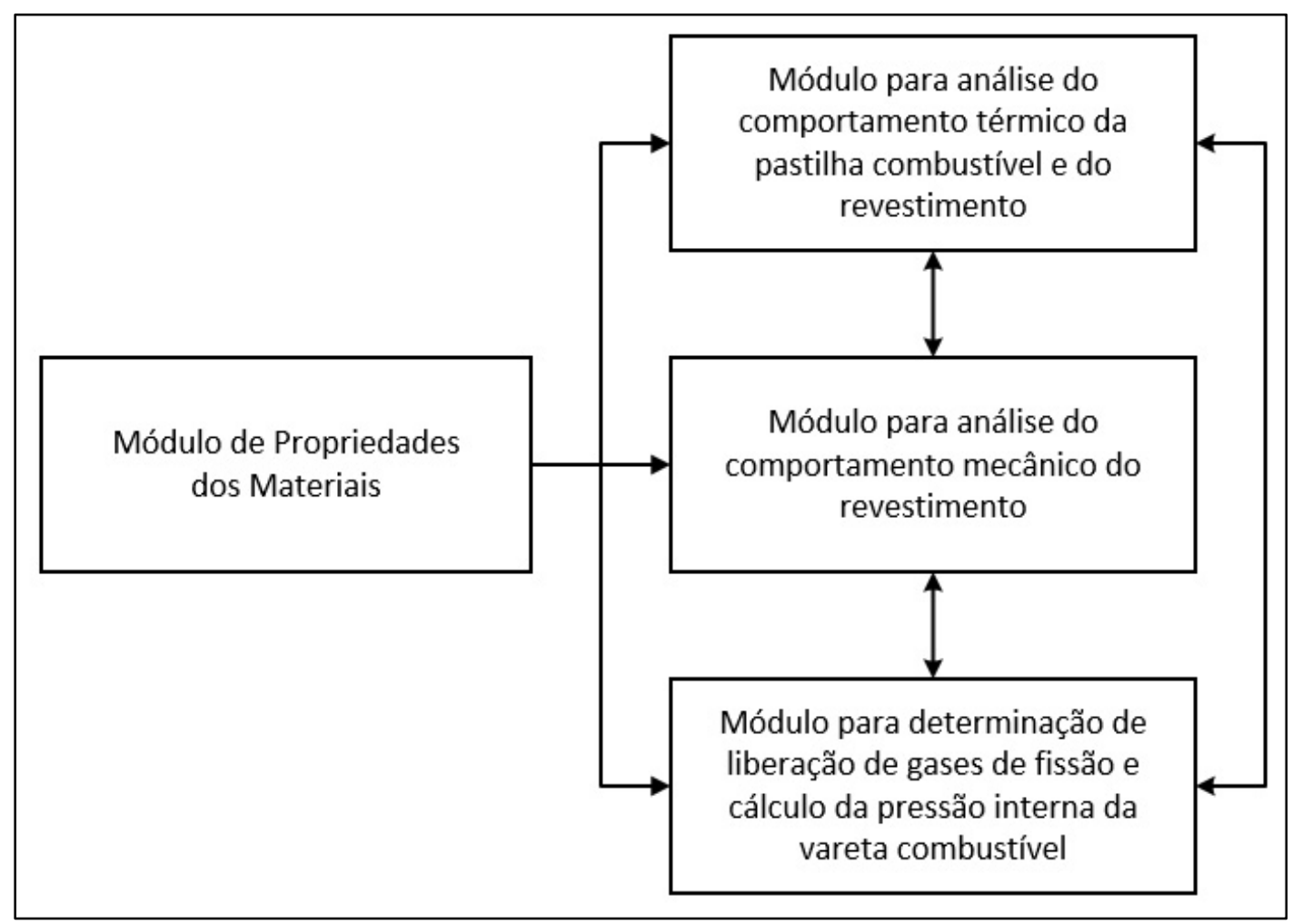

Figura 4.1 - Estrutura modular simplificada do programa computacional FRAPCON-3.4a.

Fonte: Autor.

Uma estrutura lógica mais detalhada utilizada pelo código FRAPCON-3.4a é ilustrada na Figura 4.2. Como pode ser observado nessa figura, o processamento tem início através da inserção dos dados de entrada, passando, em seguida, para a determinação das 


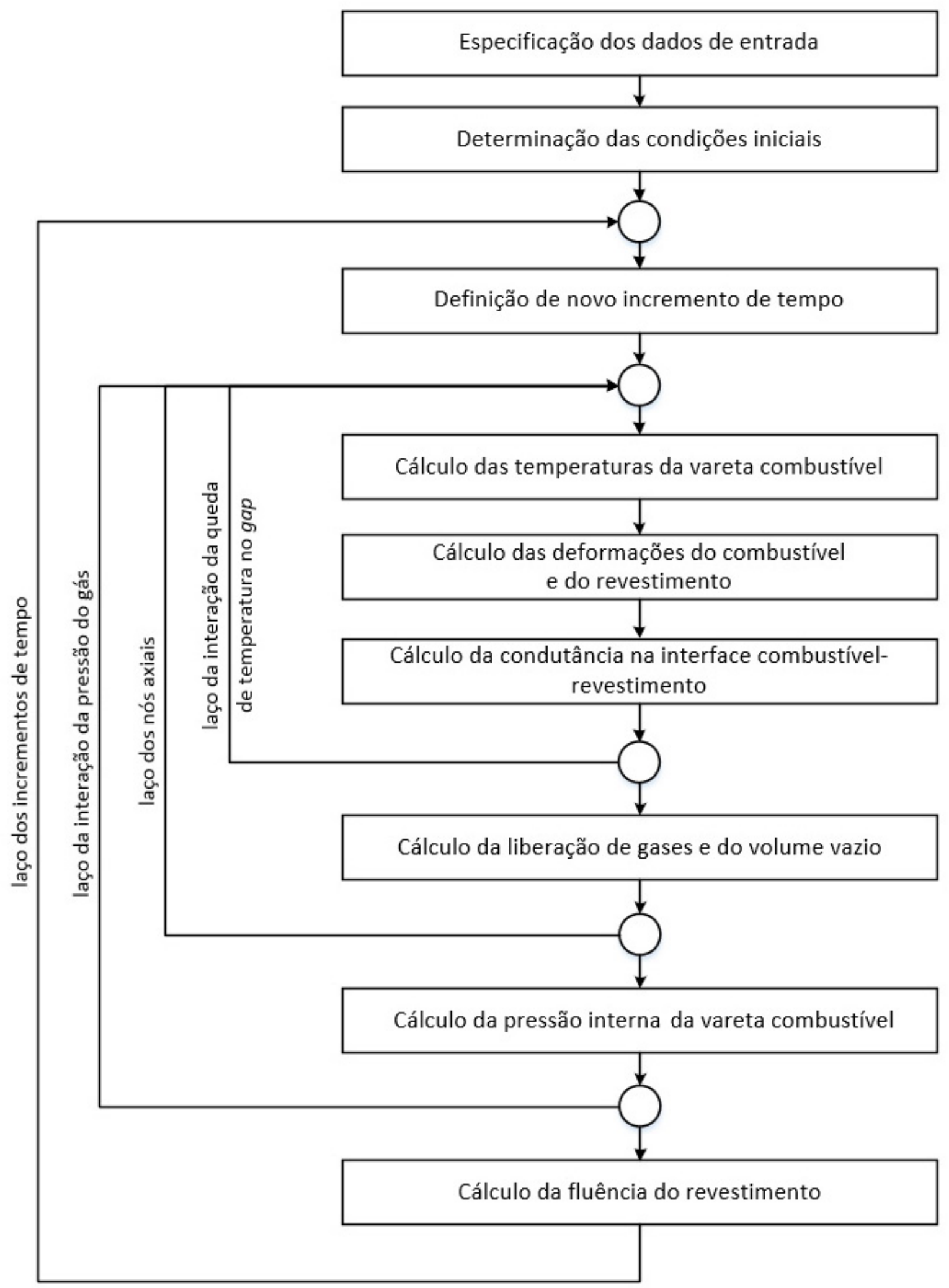

Figura 4.2 - Fluxograma simplificado do programa computacional FRAPCON-3.

Fonte: (JERNKVIST; MASSIH, 2002). 
condições iniciais da vareta combustível. Um incremento de tempo, definido nos dados de entrada, é então adicionado e uma nova condição em estado estacionário é obtida. Este novo estado serve como condição inicial para um novo incremento de tempo, que fará com que seja obtida um novo estado para a vareta combustível. O número de vezes que este procedimento será repetido é estabelecido pelo número de incrementos de tempo definido nos dados de entrada (JERNKVIST; MASSIH, 2002).

Em cada uma das etapas definidas pelos incrementos de tempo, são efetuados os seguintes procedimentos:

- Cálculo das temperaturas do refrigerante, revestimento e pastilha combustível;

- Cálculo da deformação do combustível e do revestimento;

- Cálculo da condutância na interface pastilha-revestimento;

- Cálculo da liberação de gases de físsão, volume vazio da vareta combustível e pressão interna dos gases.

Como pode ser observado no fluxograma fornecido na Figura 4.2, a condição obtida para a vareta combustível para cada nó axial em cada incremento de tempo é determinada por meio da execução contínua dos dois laços de repetição responsáveis pela convergência dos valores da temperatura na interface combustível-revestimento e da pressão interna dos gases da vareta combustível.

No laço de interação interno (queda de temperatura na interface combustívelrevestimento) é determinado, inicialmente, a distribuição de temperaturas na pastilha combustível e no revestimento, utilizando a condutância da interface pastilha-revestimento do incremento de tempo anterior. Esta distribuição de temperaturas é então utilizada para determinar a deformação ocasionada pelas expansões térmicas do combustível e do revestimento. Com os dados obtidos através destes cálculos, determina-se um novo valor para a folga (gap) existente entre o combustível e o revestimento, o qual é utilizado para determinar um novo valor de condutância na interface entre o combustível-revestimento. Este novo valor será então utilizado no próximo ciclo da interação. Este processo repetitivo no laço interno é executado continuamente até que dois ciclos sequenciais apresentem essencialmente a mesma queda de temperatura na interface combustível-revestimento (JERNKVIST; MASSIH, 2002). A Figura 4.3 ilustra de modo mais detalhado o procedimento de cálculo utilizado neste laço. 


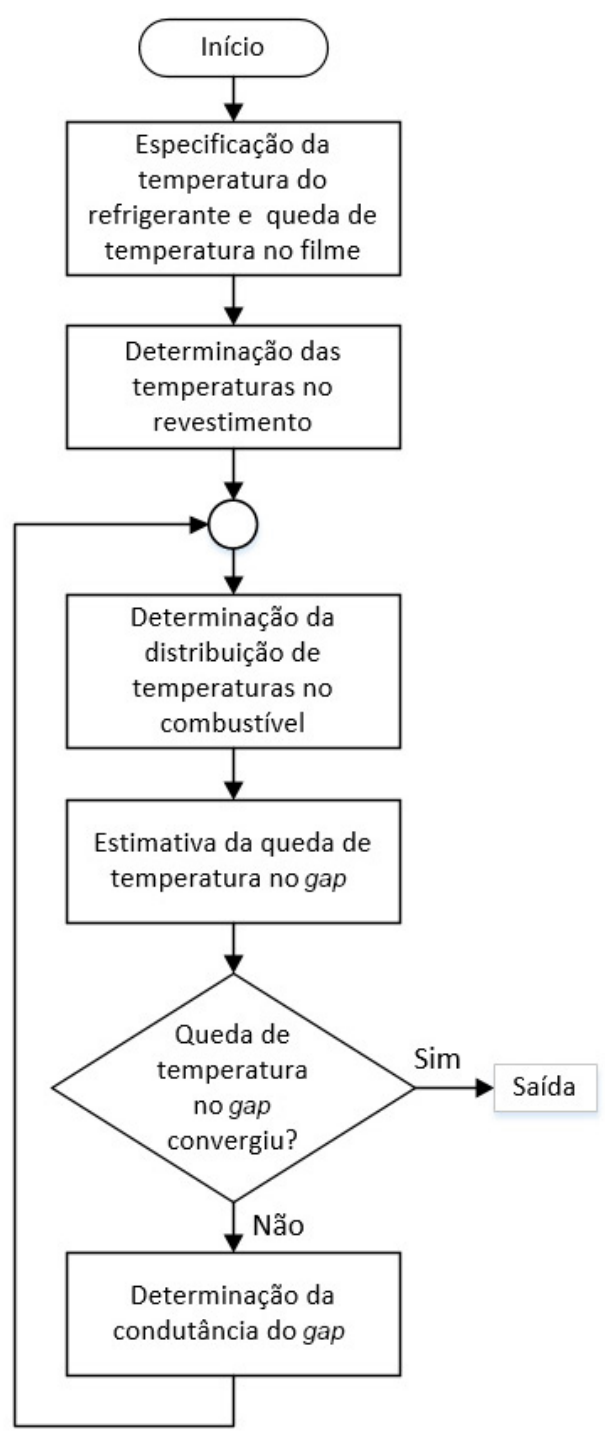

Figura 4.3 - Fluxograma do laço de convergência para a obtenção da queda de temperatura no gap. Fonte: (GEELHOOD; LUSCHER; BEYER, 2011).

O laço de interação externo (pressão do gás) possui um procedimento semelhante ao laço interno, porém com a finalidade de determinar a pressão interna dos gases da vareta combustível. Para efetuar esta tarefa, é realizado um procedimento que alterna o cálculo da pressão do gás no volume vazio da vareta combustível com o cálculo da deformação da vareta combustível. Em cada ciclo realizado pelo laço externo, o número de moles de gás é calculado e o valor da pressão do gás no interior da vareta combustível é atualizado em função da deformação da vareta combustível e da distribuição das temperaturas obtidas no laço de interação interno. Este procedimento é repetido até que dois ciclos sucessivos apresentem essencialmente o mesmo resultado para a pressão do gás no interior da vareta combustível. No momento em que esta convergência ocorre, um novo incremento de 
tempo é efetuado (JERNKVIST; MASSIH, 2002). A Figura 4.4 apresenta um fluxograma detalhado dos procedimentos executados pelo código FRAPCON-3.4a.
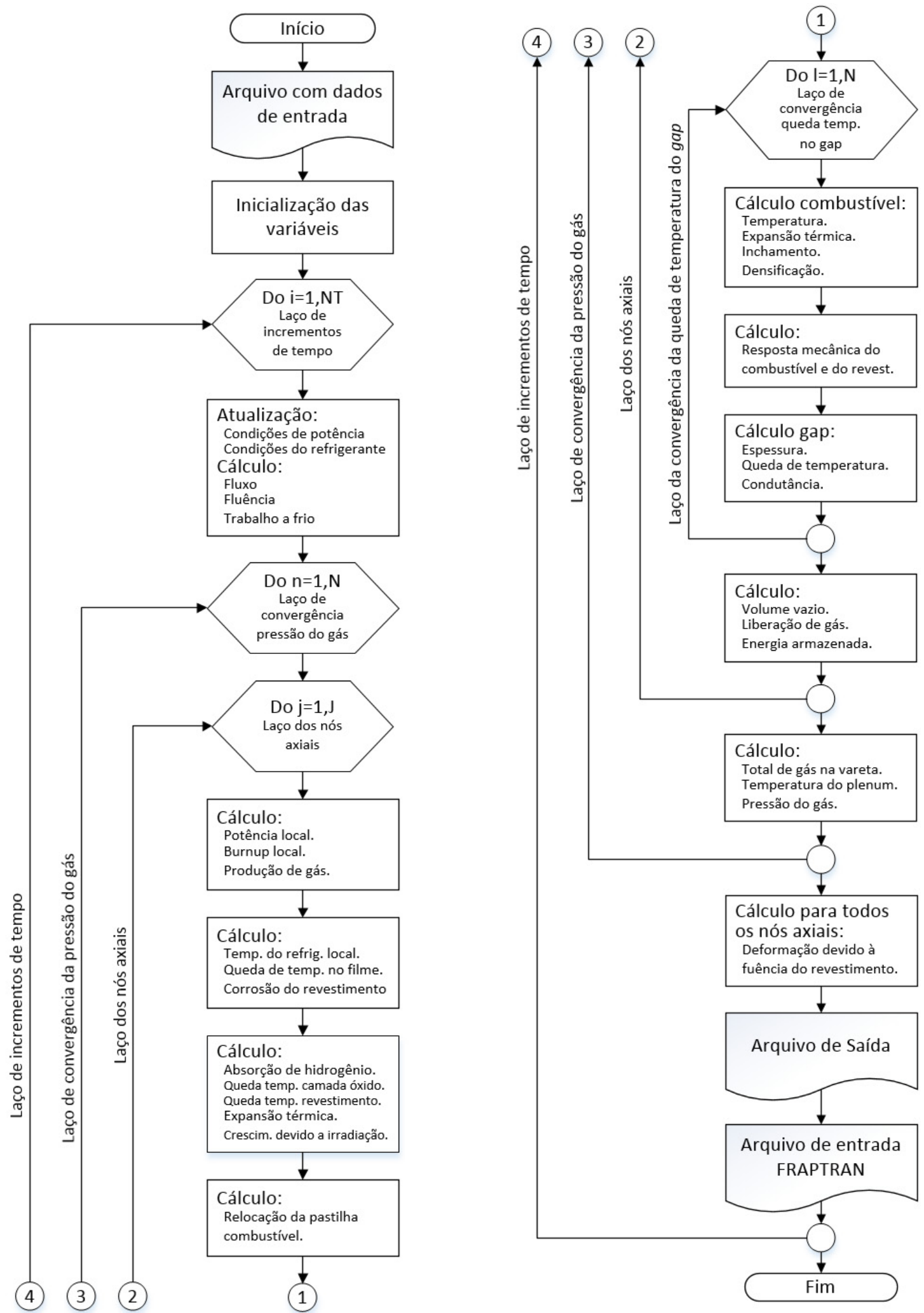

Figura 4.4 - Fluxograma do código FRAPCON-3.

Fonte: (GEELHOOD; LUSCHER; BEYER, 2011). 
O detalhamento dos modelos analíticos utilizados para a determinação do comportamento térmico e mecânico da vareta combustível encontram-se disponibilizados no manual do código FRAPCON 3.4a (GEELHOOD; LUSCHER; BEYER, 2011).

As diversas correlações empíricas utilizadas para a determinação das propriedades físicas e químicas dos materiais da pastilha combustível e do revestimento podem ser consultadas no Manual de Correlações para Propriedades dos Materiais - MATPRO (LUSCHER; GEELHOOD, 2011).

\subsection{Características do Programa Computacional FRAPTRAN-1.4}

O código computacional FRAPTRAN-1.4 é uma ferramenta analítica que determina o comportamento de varetas combustíveis de reatores de água leve (LWR) quando a potência do reator ou as condições do refrigerante, ou ambos, se alteram rapidamente em função do tempo, ou seja, sob a ação de transientes (GEELHOOD et al, 2010). Deste modo, o código determina o impacto que as variações do tempo, da potência e das condições do refrigerante acarretam nas seguintes condições operacionais da vareta combustível:

- Temperaturas do combustível, do revestimento e do refrigerante;

- Tensões e deformações elásticas e plásticas do revestimento;

- Deformações da pastilha combustível;

- Volume vazio e pressão interna da vareta combustível;

- Deformação (balloning) local do revestimento.

Condições que variam lentamente com o tempo, tais como densificação e inchamento do combustível e fluência e crescimento do revestimento, entre outras, não são calculadas pelo código FRAPTRAN. Entretanto, as condições presentes na vareta combustível no momento em que ocorre o transiente, e que são dependentes de diversas varáveis não consideradas pelo FRAPTRAN, podem ser fornecidas manualmente como dados de entrada ou, preferencialmente, através de um arquivo gerado pelo código FRAPCON. Essas características permitem que o código FRAPTRAN seja utilizado nas seguintes tarefas (GEELHOOD et al, 2010):

- Análise do comportamento de varetas combustíveis à ocorrência de acidentes postulados em projeto tais como perda do fluído refrigerante (LOCA) ou acidente inicializado por reatividade (RIA); 
- Compreender e interpretar resultados experimentais;

- Guia para planejamento de trabalhos experimentais, incluindo a determinação dos limites de desempenho aceitáveis em transientes, identificar dados e modelos necessários para compreender o desempenho do combustível sob a ação de transientes e averiguar o efeito de alterações no projeto da vareta combustível em condições de acidente;

- Realizar análises de sensibilidade dos efeitos que parâmetros, tais como, folga na interface combustível-revestimento (gap), pressão interna da vareta e ductilidade e deformação do revestimento impactam na resposta de varetas combustíveis quando submetidas a condições de transientes postulados.

O código computacional FRAPTRAN é composto de diversos subcódigos especializados que, de forma inter-relacionadas e interativa, determinam o comportamento de uma vareta combustível em condições de transientes. A Figura 4.5 ilustra a sequência de execução dos subcódigos que compõem o programa computacional FRAPTRAN-1.4 (MANNGARD, 2007). Nesta figura, pode-se observar que o código utiliza alguns modelos por padrão, e outros como modelos opcionais, podendo esses modelos opcionais serem ativados ou não pelos dados de entrada.

A execução do código FRAPTRAN-1.4 se inicia pelo processamento dos dados de entrada. Em seguida, são determinadas as condições da vareta combustível, por meio de cálculos em estado estacionário, que serão utilizadas para dar início à análise do transiente. Incrementos de tempo são definidos através dos dados de entrada e uma nova condição da vareta combustível é estabelecida para cada incremento de tempo, levando-se em consideração o histórico de potência definido nos dados de entrada. Cada nova condição da vareta combustível é utilizada como condição inicial para o incremento de tempo seguinte, até que o intervalo de tempo final seja atingido.

Através da utilização dos modelos utilizados como padrão para a execução do código, obtém-se as seguintes informações:

- Determinação da condutância na interface combustível-revestimento (gap) e temperaturas no combustível e no revestimento;

- Cálculo das deformações do combustível e do revestimento;

- Cálculo do volume vazio e da pressão interna da vareta combustível;

- Cálculo do deformação (balloning) local do revestimento (caso a deformação de instabilidade tenha sido atingida). 


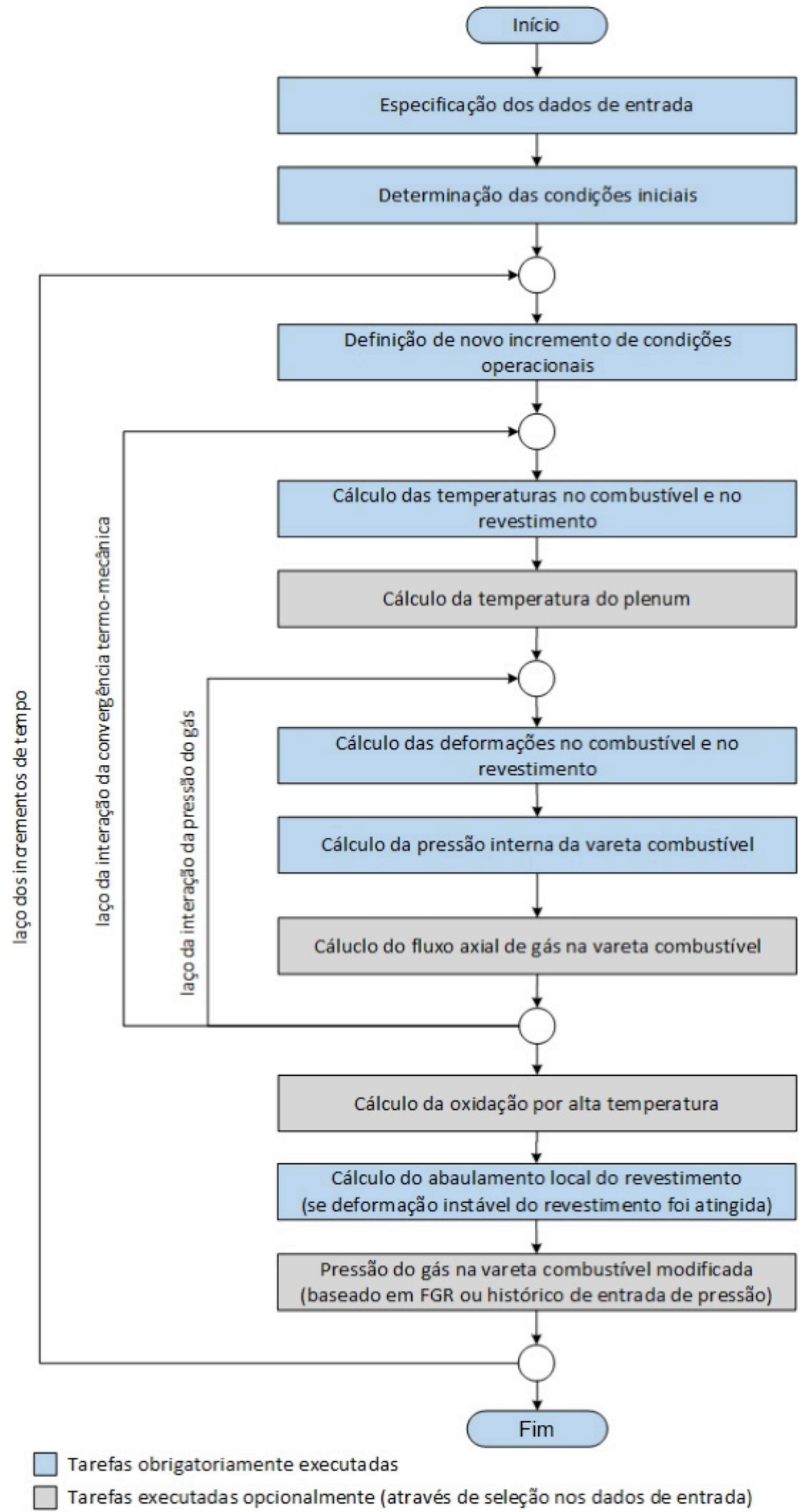

Figura 4.5 - Fluxograma indicando a sequência de execução dos modelos presentes no código FRAPTRAN-1.4.

Fonte: MANNGARD, 2007. 
Através da ativação dos modelos opcionais, as seguintes informações podem ser obtidas:

- Cálculo da temperatura do plenum devido à troca de energia entre o gás presente no plenum com os componentes estruturais;

- Cálculo do fluxo axial de gás no interior da vareta combustível;

- Cálculo da oxidação a altas temperaturas;

- Modificação da pressão de gás no interior da vareta de acordo com uma taxa de liberação de gases de fisssão fornecida nos dados de entrada ou por intermédio de um histórico de pressão de gás ao longo do tempo.

Como pode ser observado na Figura 4.6 (GEELHOOD et al, 2010), a qual fornece um fluxograma detalhado da estrutura lógica do código FRAPTRAN-1.4, por meio de um processo interativo são efetuados os cálculos das temperaturas, das deformações e da pressão interna para cada segmento axial da vareta combustível.

Dentro dos laços de interação, inicialmente é determinada a distribuição de temperaturas na pastilha combustível e no revestimento. A seguir, esta distribuição de temperaturas é utilizada para alimentar o modelo responsável pela resposta mecânica (tensões e deformações) da vareta combustível, levando em consideração variáveis como as expansões térmicas do combustível e do revestimento e a relação tensão-deformação do revestimento.

Após executados os módulos térmicos e mecânicos, uma nova dimensão da folga pastilha-revestimento (gap) é obtida, a qual é utilizada para o cálculo da condutância no gap que será utilizada no próximo ciclo de cálculos. Neste ponto, também é atualizado o valor da quantidade de gás liberado (FGR), calculado o novo volume livre da vareta combustível e determinada a nova pressão do gás no interior da vareta combustível. Esses cálculos são repetidos até que ocorra a convergência da distribuição de temperaturas e da pressão do gás em dois ciclos sucessivos.

Após a convergência das temperaturas e da pressão do gás, é determinada a oxidação e o deformação (balloning) local do revestimento. Esses cálculos são efetuados apenas uma vez a cada incremento de tempo. 


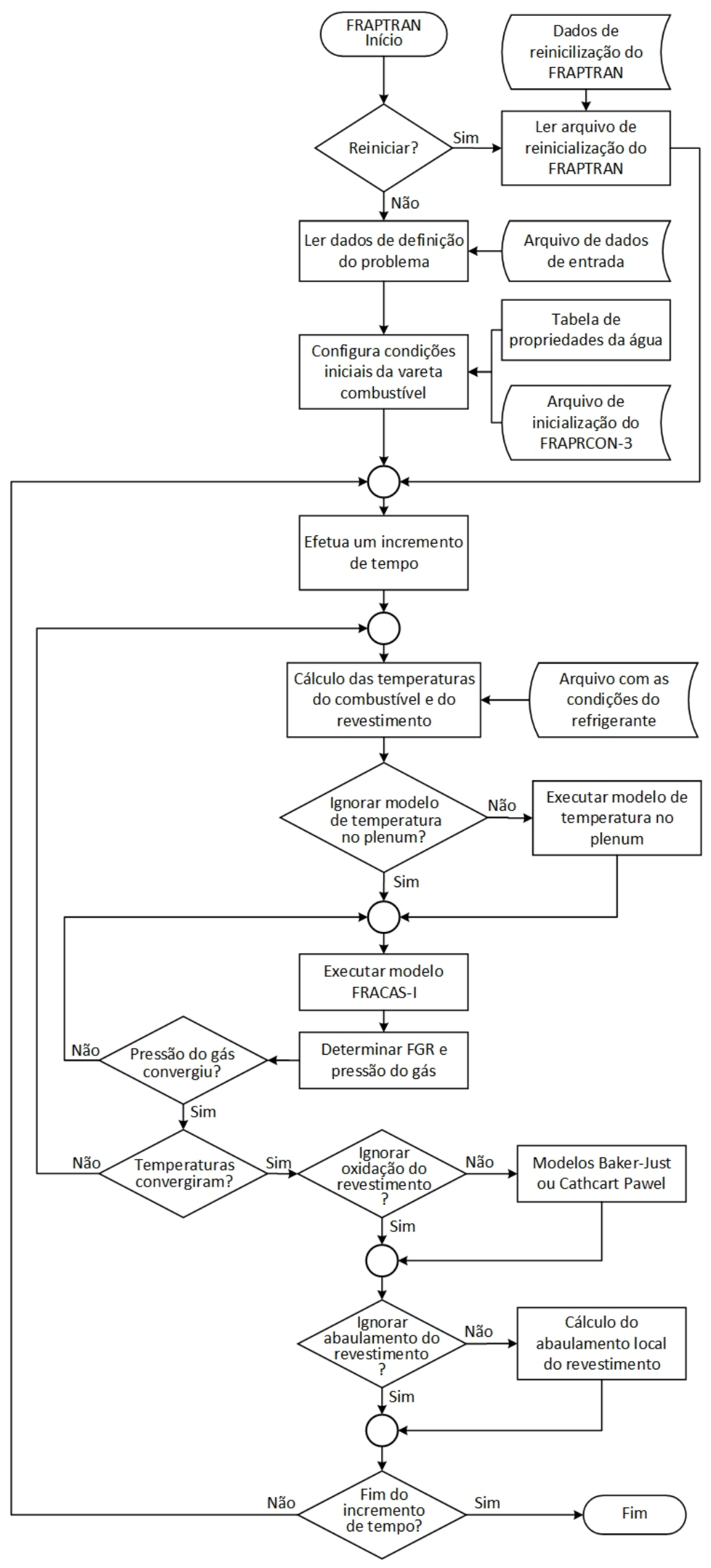

Figura 4.6 - Fluxograma detalhado do código FRAPTRAN-1.4.

Fonte: GEELHOOD et al., 2010. 


\section{COMPARAÇÃO DOS RESULTADOS OBTIDOS ATRAVÉS DOS CÓDIGOS FRAPCON-3.4a E FRAPTRAN-1.4 COM OS DADOS FORNECIDOS PELO PROGRAMA EXPERIMENTAL FUMEX III.}

Neste capítulo foram realizadas análises com a finalidade de comparar dados obtidos experimentalmente por meio do programa FUMEX III com resultados fornecidos através de simulação computacional utilizando os códigos FRAPCON-3.4a (regime estacionário) e FRAPTRAN-1.4 (transientes).

As análises que foram realizadas envolvem varetas combustíveis utilizadas em reatores PWR, em regimes de alta queima (superiores a $45 \mathrm{MWd} / \mathrm{kgU}$ )

\subsection{Comparação dos Dados Fornecidos Pelo Programa FRAPCON-3.4a com os Dados Fornecidos pelo Experimento IFPE/US-PWR-16x16 LTA (NEA-1738/01).}

O experimento US-PWR-16x16-LTA foi realizado durante a década de 1980 nos Estados Unidos, em um reator PWR comercial, com a finalidade de demonstrar o comportamento de varetas combustíveis em regimes de alta queima.

Neste experimento, foram utilizados dois elementos combustíveis de testes, denominados D039 e D040. Cada um desses elementos era constituído por um conjunto de 236 varetas combustíveis montadas em uma matriz 16x16, com cinco tubos guias para varetas de controle e doze grades espaçadoras. A grade espaçadora inferior foi construída com Inconel 625. Todas as outras grades espaçadoras e todos os tubos guia foram construídos com Zircaloy-4.

Nos experimentos realizados, foram utilizadas quatro tipos de varetas combustíveis:

1. Varetas com pastilhas combustíveis cilíndricas e sólidas de $\mathrm{UO}_{2}$. Essas varetas são denominadas no experimento como varetas TSQ002 e referenciadas como montagem padrão, sendo o tipo de vareta selecionado para as análises realizadas no presente trabalho;

2. Varetas com pastilhas combustíveis anulares de $\mathrm{UO}_{2}$;

3. Varetas com pastilhas combustíveis sólidas de $\mathrm{UO}_{2}$ com tamanho de grãos grande (da ordem de $35 \mu \mathrm{m}$ ) em oposição ao tamanho de grãos das pastilhas padrão (da ordem de 7 a $12 \mu \mathrm{m}$ );

4. Varetas com revestimento revestido de grafite na parte interna (aproximadamente $8 \mu \mathrm{m}$ de espessura). 
Em todas as montagens foi utilizado o Zircaloy-4 como material do tubo de revestimento e dos tampões das varetas combustíveis.

O elemento combustível de testes D039 foi submetido a três ciclos de irradiação com uma exposição total de 885 dias efetivos de potência máxima, enquanto o elemento D040 foi submetido a cinco ciclos de irradiação com uma exposição total de 1.641 dias efetivos de potência máxima. A queima atingida para cada uma das montagem é idêntica ao longo dos três primeiros ciclos de irradiação, devido à sua colocação em posições centrais simétricas, e envolvem valores médios da ordem de $39 \mathrm{MWd} / \mathrm{kgU}$. Para o elemento D040, foi atingido uma queima média de aproximadamente $58 \mathrm{MWd} / \mathrm{kgU}$, uma vez que este foi submetido a dois ciclos adicionais de irradiação.

A Tabela 5.1 fornecida a seguir apresenta as principais características das varetas combustíveis TSQ002 utilizadas no experimento US-PWR-16x16-LTA.

Tabela 5.1 - Características da vareta combustível TSQ002 no início e no final de vida.

\begin{tabular}{l|l}
\hline Diâmetro externo da pastilha $(\mathrm{mm})$ & 8,255 \\
\hline Altura da pastilha $(\mathrm{mm})$ & 9,91 \\
\hline Chanfro e dish & Sim \\
\hline Altura da coluna de pastilhas $(\mathrm{mm})$ & 3810 \\
\hline Enriquecimento $\left(\% \mathrm{U}^{235}\right)$ & 3,48 \\
\hline Diâmetro interno do revestimento $(\mathrm{mm})$ & 8,43 \\
\hline Diâmetro externo do revestimento $(\mathrm{mm})$ & 9,70 \\
\hline Pressão do gás de enchimento $(\mathrm{MPa})$ & $2,62(\mathrm{He})$ \\
\hline Volume livre inicial (ml) & 25,42 \\
\hline Queima média da vareta $(\mathrm{MWd} / \mathrm{kgU})$ & 53,24 \\
\hline Volume livre no final da vida $(\mathrm{ml})$ & 17,8 \\
\hline$\Delta$ volume livre $(\mathrm{ml})$ & $-7,62$ \\
\hline$\Delta$ volume gás $(\mathrm{EOL}-\mathrm{BOL})(\%)$ & 5,7 \\
\hline
\end{tabular}

Fonte: Base da Dados FUMEX-III - IAEA.

\subsubsection{Simulação Computacional de Uma Vareta Combustível Tipo TSQ002 com o código FRAPCON-3.4a.}

Para a simulação do comportamento de uma vareta combustível TSQ002 utilizada no experimento IFPE/US-PWR-16x16 utilizando o programa computacional FRAPCON3.4a, foi elaborado o arquivo de dados de entrada fornecido no Apêndice 1. Este arquivo 
foi montado por intermédio da utilização de informações fornecidas pelo documento "USPWR $16 x 16$ LTA Extended Burnup Demonstration Program (Summary File, Revision 1, March 2005)", fornecido pela Base de Dados FUMEX III.

No Apêndice 1 também é fornecido o resumo da saída fornecida pelo código FRAPCON-3.4a para o caso em questão. A saída completa não é fornecida pelo fato de ser muito extensa.

\subsubsection{Comparação dos Dados Obtidos Através da Simulação Computacional com os Dados Experimentais.}

Os dados documentados pelo relatório final FUMEX III para o experimento IFPE/US-PWR-16x16-LTA, vareta TSQ002, tornam possível a realização das seguintes análises:

- Liberação dos gases de fissão;

- Volume livre da vareta combustível no final da vida;

- Pressão interna da vareta combustível;

- Fluência do revestimento.

Apesar do programa FUMEX III não fornecer, para este experimento, dados relacionados à temperatura do combustível e à pressão interna da vareta combustível, o relatório final do programa FUMEX III apresenta uma análise com relação a essas grandezas utilizando dados fornecidos pelos códigos computacionais utilizados pelos participantes do programa. Essas análises também foram realizadas neste estudo.

\subsubsection{Temperatura Central da Pastilha Combustível.}

A base de dados fornecida pelo programa FUMEX III não apresenta, para este experimento, dados relacionados à distribuição das temperaturas na pastilha combustível. Entretanto, o relatório final FUMEX III (IAEA-FUMEX-III, 2013) fornece, para o experimento em questão, um gráfico com a temperatura na região central da pastilha combustível em função da queima obtida através de simulação computacional realizada pelos códigos que participaram do projeto. Este gráfico é mostrado na Figura 5.1.

Os resultados apresentados nesta figura são de interesse para este trabalho, pois permitem que seja realizada uma comparação do resultado fornecido pelo código 
FRAPCON-3.4a com os resultados fornecidos pelos demais códigos. Adicionalmente, serve como validação do arquivo de dados de entrada preparado para a execução do código FRAPCON-3.4a relacionado a este experimento.

A Figura 5.2 apresenta o resultado obtido para a temperatura na região central da pastilha combustível em função da queima por meio da execução do código FRAPCON3.4a para este experimento.

Comparando-se as Figuras 5.1 e 5.2 pode-se observar que existe uma boa convergência dos dados fornecidos pelo código FRAPCON-3.4a com os dados fornecidos pelos demais códigos, existindo uma variação com relação à média dos valores em torno de $100{ }^{\circ} \mathrm{C}$, valor considerado aceitável pelo relatório FUMEX-III.

\subsubsection{Liberação de gás de fissão.}

No que se refere ao percentual liberado de gases de fissão, o experimento obteve um valor $1,18 \%$ do total de gás produzido no final de vida da vareta combustível (queima aproximada de $58 \mathrm{MWd} / \mathrm{kgU}$ ). Este valor encontra-se plotado no gráfico fornecido na Figura 5.3, a qual também fornece os valores obtidos para a liberação de gases de fissão através do emprego dos códigos computacionais empregados pelos participantes do programa FUMEX-III.

A Figura 5.4 mostra a comparação entre o resultado obtido por meio do experimento com o resultado obtido através da utilização do código FRAPCON-3.4a. Nesta figura se observa uma discrepância relativamente acentuada do resultado fornecido pelo código quando comparado ao resultado obtido experimentalmente, sendo que o resultado fornecido pelo código possui um valor aproximadamente $66 \%$ maior que o resultado obtido experimentalmente.

A explicação mais plausível relativa à tal discrepância se deve à complexidade dos fenômenos envolvidos no processo de liberação de gases de fissão, conforme abordado no Item 2.2.1.6 da revisão bibliográfica. Esta complexidade torna difícil a elaboração de modelos que permitam simular comportamento da liberação de gases de fissão na pastilha combustível. Outro fator que apoia esta hipótese é a grande dispersão dos resultados fornecidos pelos diversos códigos empregados. Como pode ser observado na Figura 5.3, existe uma grande divergência entre os resultados fornecidos pelos modelos empregados pelos códigos para representar a quantidade de gás liberado pelo combustível. 


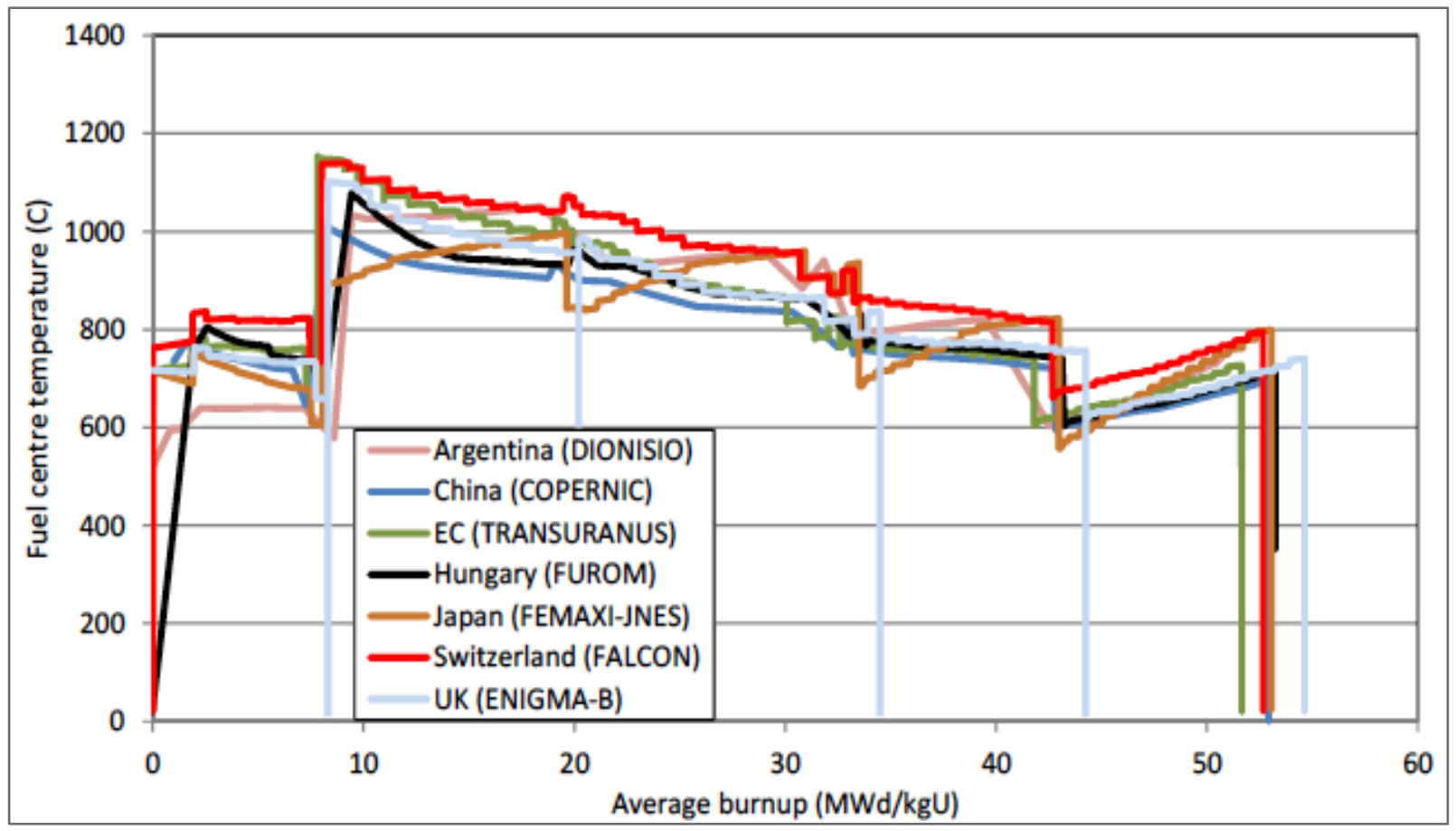

Figura 5.1 - Variação da temperatura da região central da vareta combustível em função da queima.

Fonte: Relatório Final FUMEX III.

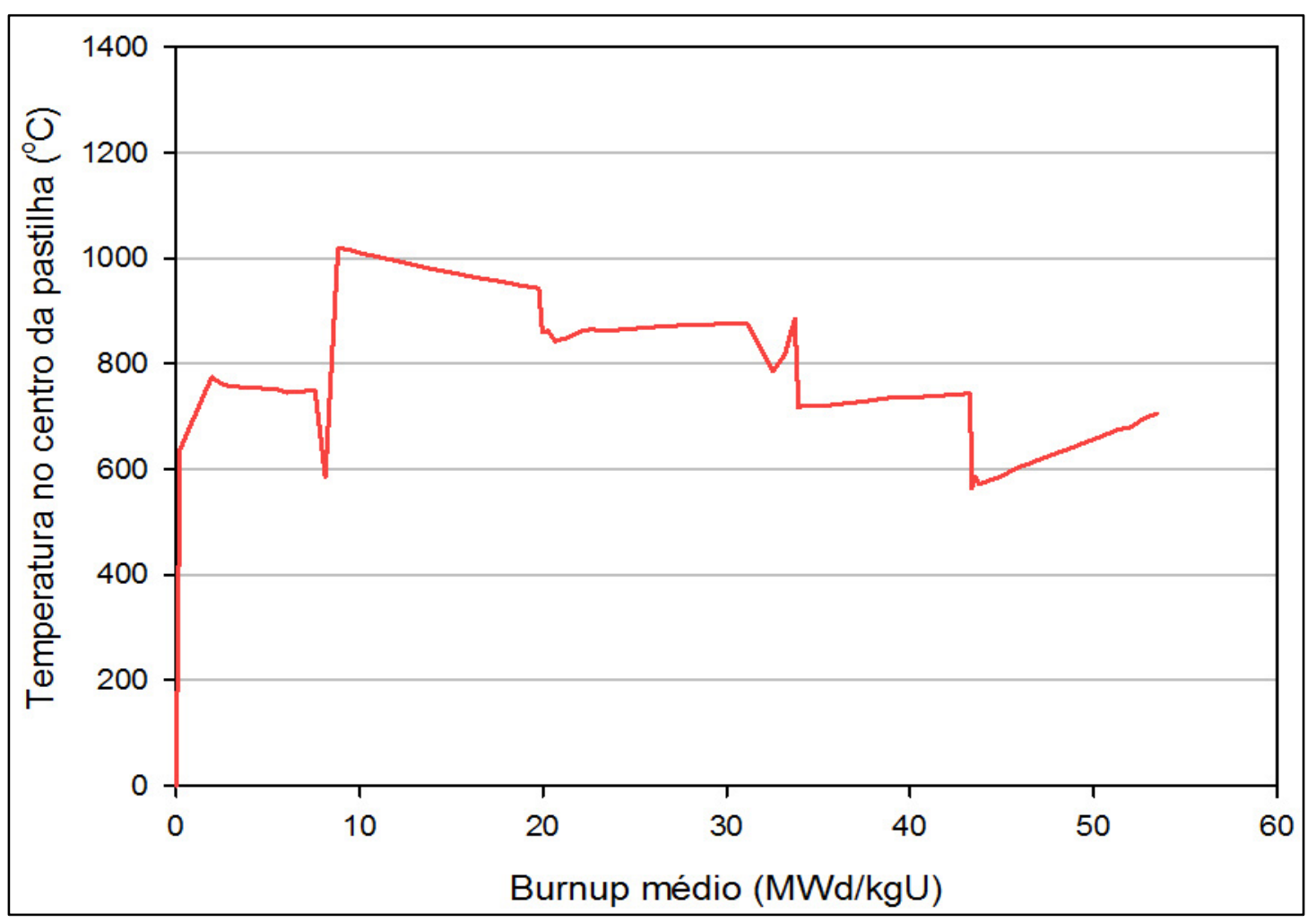

Figura 5.2 - Variação da temperatura da região central da vareta combustível em função da queima fornecida pelo código FRAPCON-3.4a.

Fonte: Autor. 


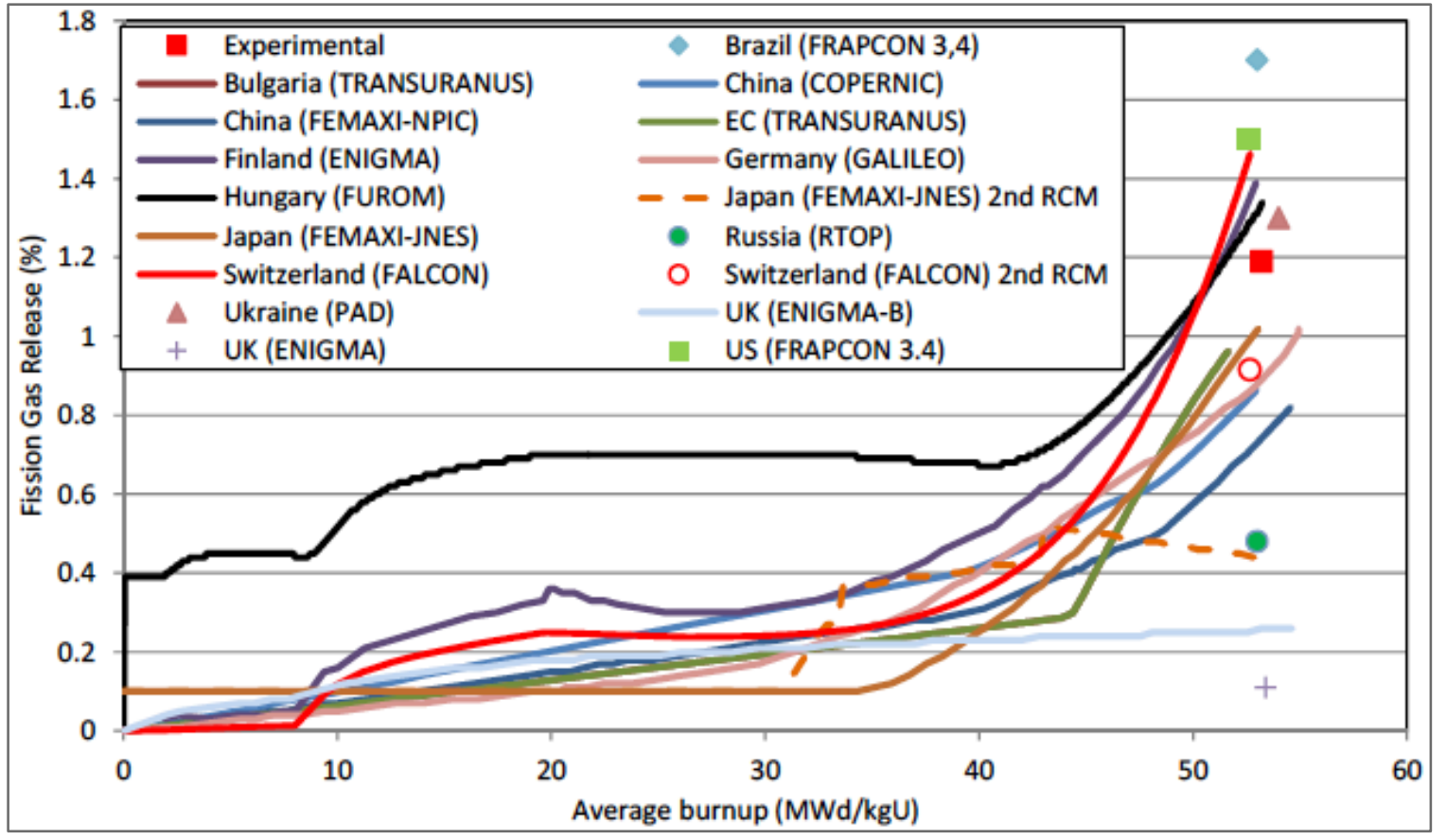

Figura 5.3 - Valor experimental e predições dos códigos computacionais para a liberação de gás de fissão.

Fonte: Relatório Final FUMEX III.

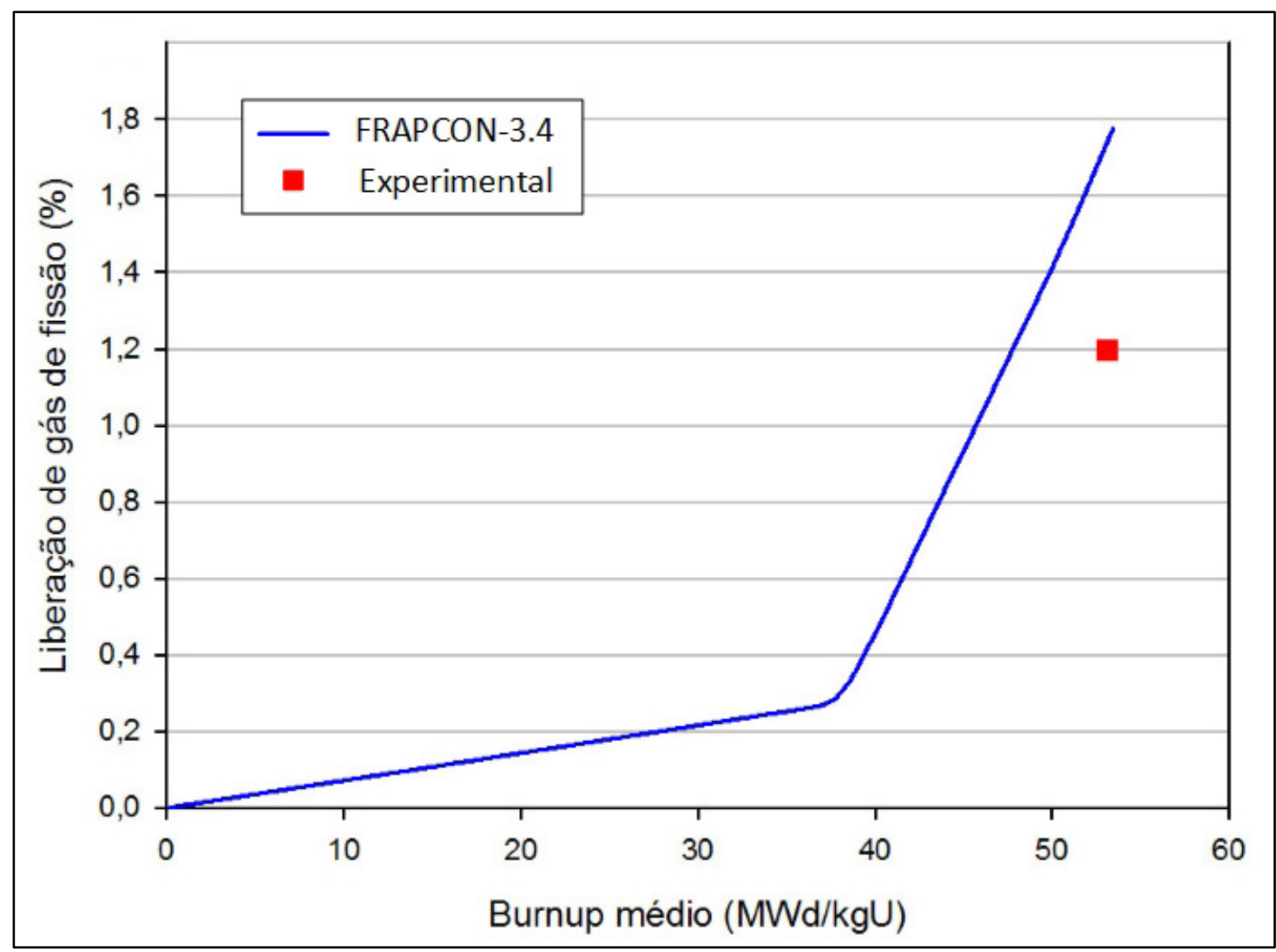

Figura 5.4 - Valor experimental e predição do código FRAPCON-3.4a para a liberação de gás de fissão.

Fonte: Autor. 
Apesar da discrepância observada no resultado, um fato à favor do resultado fornecido pelo código FRAPCON-3.4a para a liberação de gás de fissão é que o resultado fornecido pelo código é conservativo quando comparado ao valor experimental, o que é desejável para a validação das condições de projeto de uma vareta combustível.

\subsubsection{Volume livre no interior da vareta combustível.}

A determinação do volume livre no interior da vareta combustível é de fundamental importância para o cálculo de sua pressão interna. $\mathrm{O}$ valor experimental obtido no final da vida para a vareta de teste TSQ002 foi de 17,8 $\mathrm{ml}$. Este valor encontra-se plotado no gráfico fornecido na Figura 5.5, comparado com valores obtidos através do emprego dos códigos computacionais utilizados pelos participantes do programa FUMEX-III.

A Figura 5.6 mostra a comparação do valor obtido experimentalmente com o resultado fornecido pelo código FRAPCON-3.4a para a determinação do volume livre da vareta combustível, considerando as condições empregadas no experimento. Nesta figura, pode ser observado que ocorre uma boa convergência entre o resultado experimental e o valor fornecido pelo código.

\subsubsection{Pressão interna da vareta combustível.}

Apesar do experimento IFPE/US-PWR-16x16-LTA não ter fornecido resultados referentes à pressão interna existente no final da vida da vareta combustível, uma análise comparativa dos resultados obtidos pelos códigos computacionais utilizados pelos vários participantes do projeto foi apresentada no relatório final FUMEX III. Os dados obtidos nesta análise encontram-se fornecidos na Figura 5.7.

A Figura 5.8 ilustra o resultado obtido para a variação da pressão interna na vareta combustível TSQ002 através da utilização do código FRAPCON-3.4a para as condições empregadas no experimento.

A comparação das Figuras 5.7 e 5.8 mostra que o resultado fornecido pelo programa FRAPCON-3.4a se apresenta dentro do esperado quando comparado com os resultados fornecidos pelos demais códigos empregados nesta análise. As variações existentes entre os resultados fornecidos pelos diversos códigos se deve, principalmente, à variação da quantidade de gás de fissão liberada, a qual varia significativamente de código para código, conforme comentado no Item 5.2.2. 


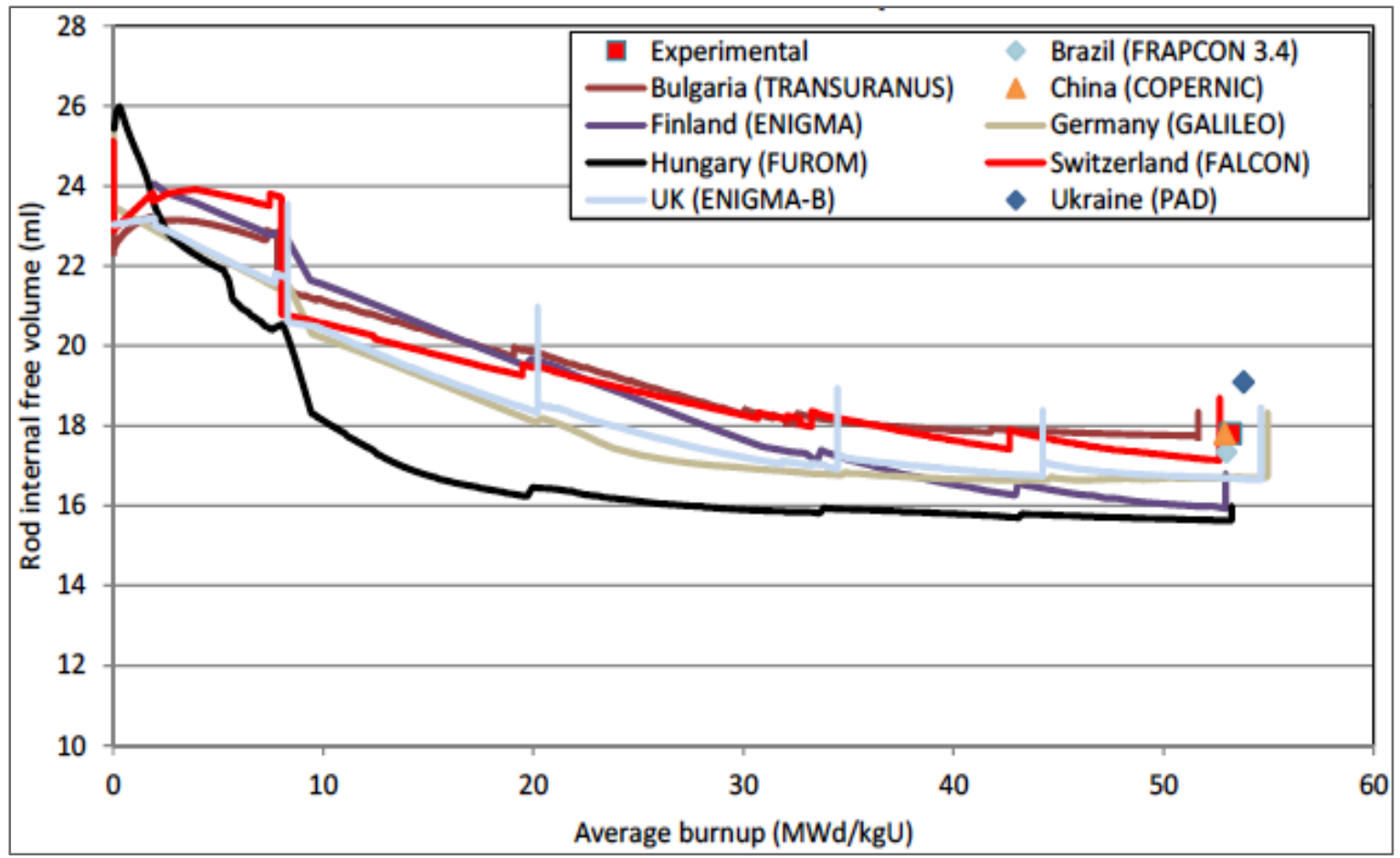

Figura 5.5 - Valor experimental e predições dos códigos computacionais para a volume livre no interior da vareta combustível.

Fonte: Relatório Final FUMEX III.

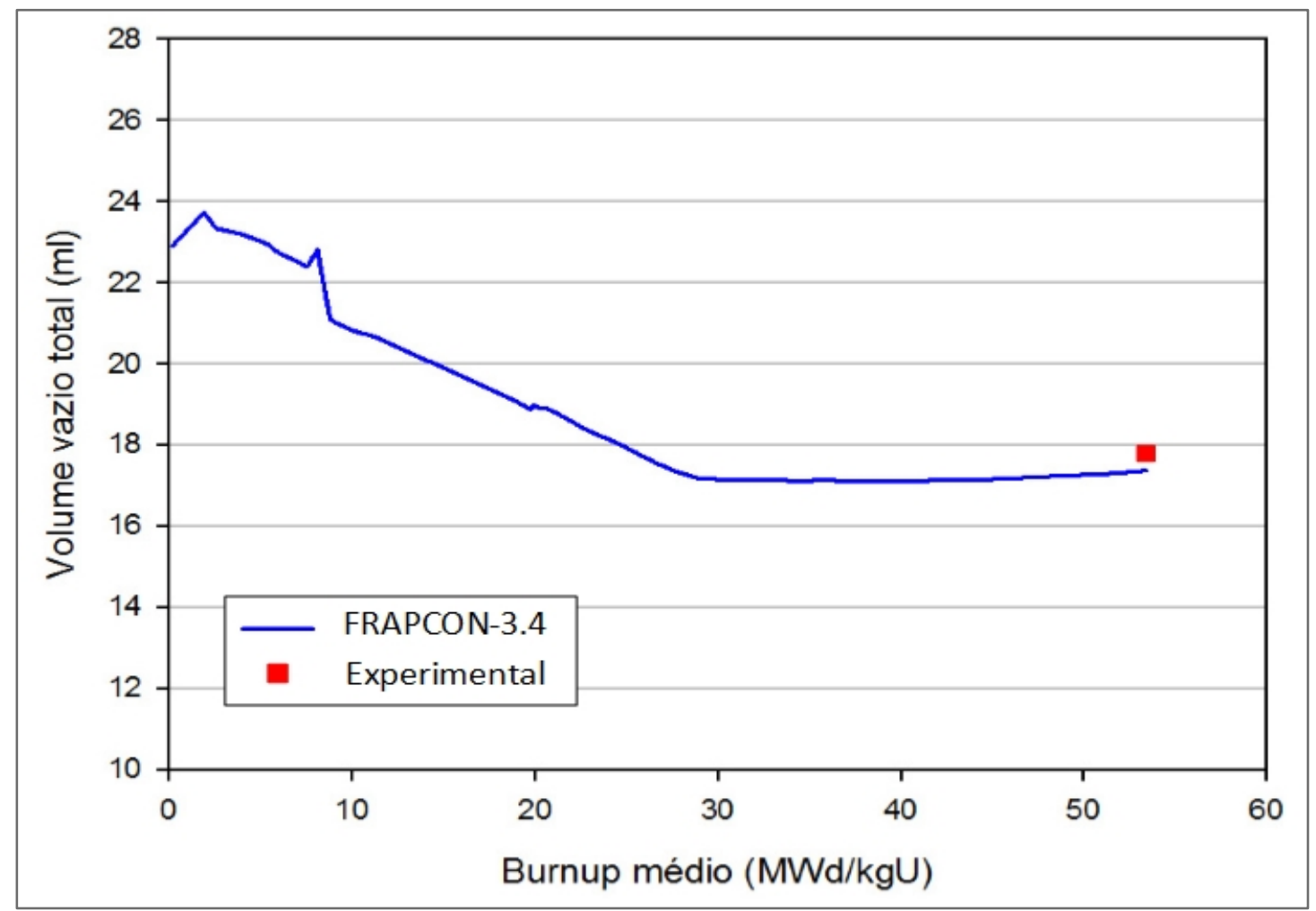

Figura 5.6 - Valor experimental e predição do código FRAPCON-3.4a para a determinação do volume livre da vareta combustível.

Fonte: Autor. 


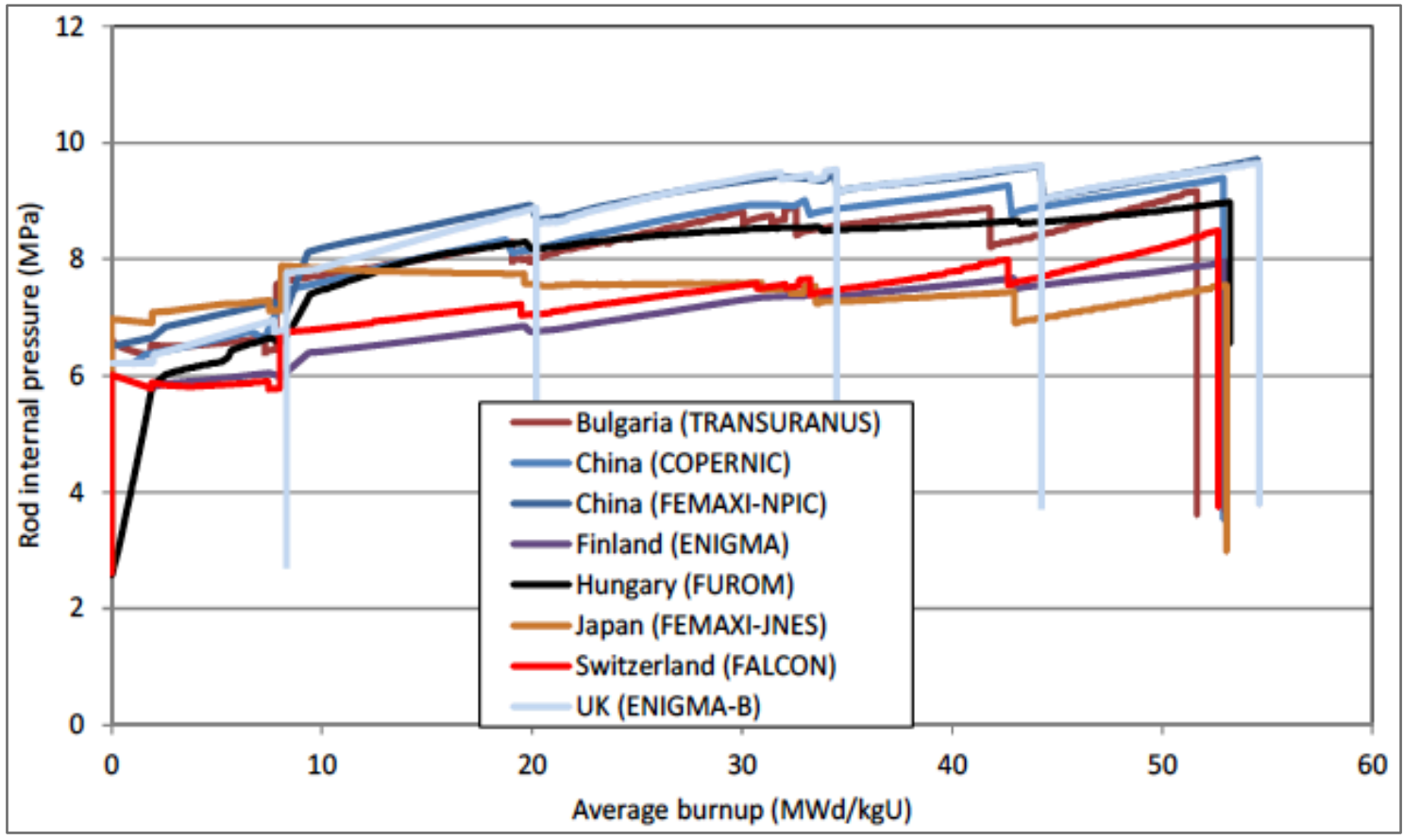

Figura 5.7 - Predições dos códigos computacionais para pressão interna da vareta combustível. Fonte: Relatório Final FUMEX III.

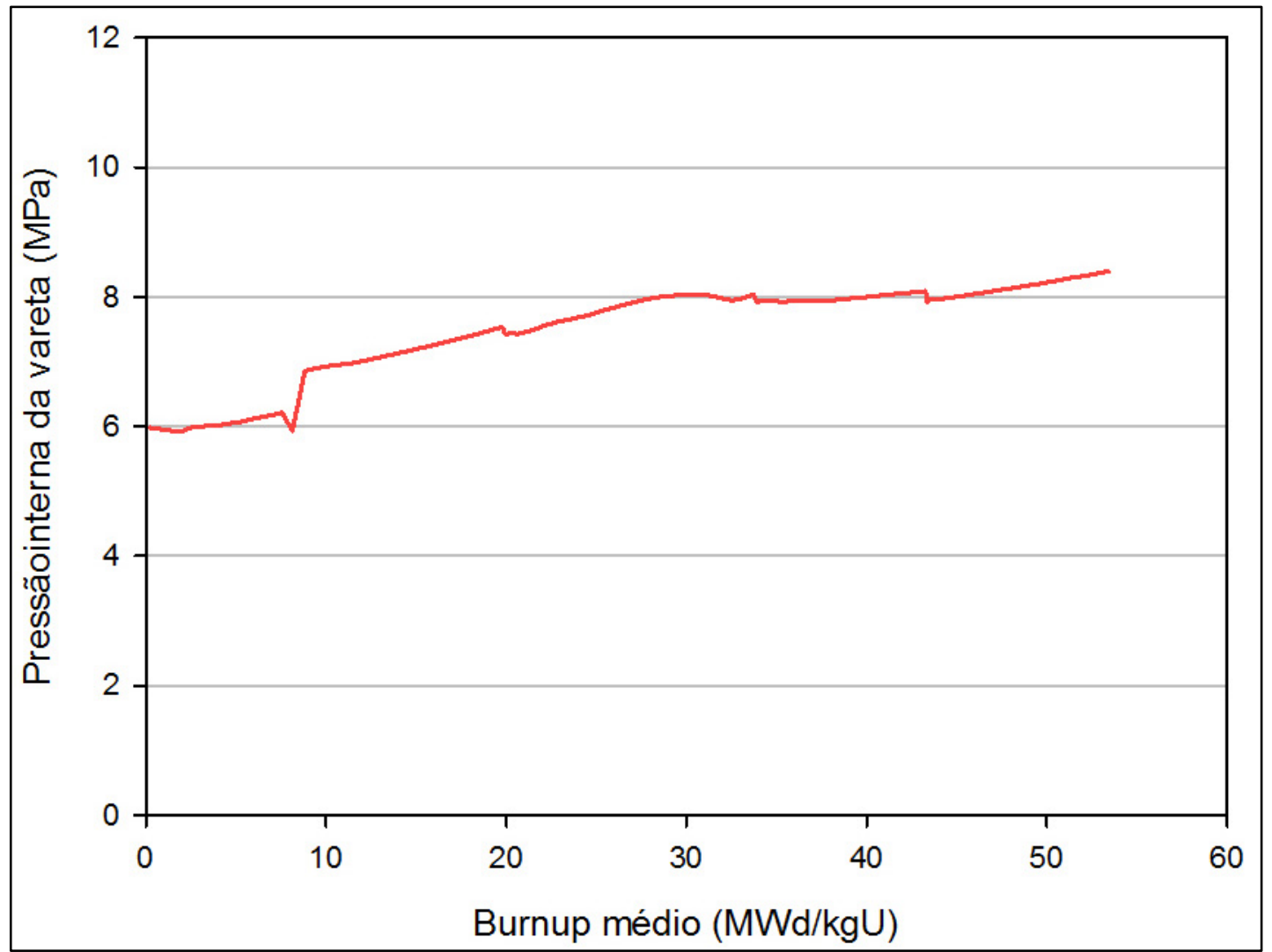

Figura 5.8 - Variação da pressão interna da vareta combustível em função da queima fornecida pelo código FRAPCON-3.4a.

Fonte: Autor. 


\subsection{Comparação dos Dados Fornecidos Pelo Programa FRAPCON-3.4a com os Dados Fornecidos pelo Experimento IFPE/RISOEIII-GE7 (NEA-1493/17).}

O experimento IFPE/RISOEIII-GE7 (NEA-1493/17) faz parte de um projeto composto de três programas de irradiação de varetas combustíveis em rampa de potência lenta, denominados "bump tests", com o objetivo de avaliar a liberação de gás de fissão e alterações microestruturais do combustível. O terceiro e último projeto, cujos dados serão utilizados no presente trabalho, envolveu a irradiação de varetas combustíveis utilizadas em reatores PWR e BWR e foi realizado no período de 1986 a 1990.

As características das varetas combustíveis utilizadas neste experimento são fornecidas na Tabela 5.2.

Tabela 5.2 - Características da vareta combustível ZX115 utilizada no experimento RISOEIII-GE7.

\begin{tabular}{l|l}
\hline Diâmetro externo da pastilha $(\mathrm{mm})$ & 10,41 \\
\hline Altura da pastilha $(\mathrm{mm})$ & 10,41 \\
\hline Chanfro & Sim \\
\hline Densidade $(\% \mathrm{DT})$ & 95,2 \\
\hline $\begin{array}{l}\text { Densidade após resinterização } \\
\left(1700{ }^{\circ} \mathrm{C}, 24 \mathrm{~h}\right)(\% \mathrm{DT})\end{array}$ & 95,6 \\
\hline Porosidade aberta (\%) & $0,03-0,05$ \\
\hline Tamanho de grão - 2D ( $\mu \mathrm{m})$ & $11,3-12,8$ \\
\hline Enriquecimento $\left(\% \mathrm{U}^{235}\right)$ & 3,0 \\
\hline Diâmetro interno do revestimento $(\mathrm{mm})$ & 10,63 \\
\hline Diâmetro externo do revestimento $(\mathrm{mm})$ & 12,26 \\
\hline Espessura da parede do revestimento $(\mathrm{mm})$ & 0,815 \\
\hline Pressão do gás de enchimento (bar) & 2,9 \\
\hline Volume livre inicial (cc) & 12 \\
\hline Gás de enchimento & $\mathrm{He}$ \\
\hline Comprimento do plenum (mm) & 143,4 \\
\hline Comprimento da coluna de pastilhas $(\mathrm{mm})$ & 752,1 \\
\hline Peso da coluna de pastilhas $(\mathrm{g})$ & 659 \\
\hline Gap diametral (mm) & 0,22 \\
\hline
\end{tabular}

Fonte: Base da Dados FUMEX-III - IAEA. 


\subsubsection{Simulação computacional da vareta combustível utilizada no experimento RISOEIII-GE7 através do código FRAPCON-3.4a.}

Para a simulação do comportamento da vareta combustível utilizada no experimento IFPE/RISOEIII-GE7 (NEA-1493/17) utilizando o programa computacional FRAPCON-3.4a, foi elaborado o arquivo de dados de entrada disponibilizado no Apêndice 2. Este arquivo foi montado por intermédio da utilização de informações fornecidas pelo documento "The Third Riso Fission Gas Project - Bump Test GE7 - ZX115 (September, 1990) ’, fornecido pela Base de Dados FUMEX III.

No Apêndice 2 também é fornecido o resumo da saída fornecida pelo código FRAPCON-3.4a para o caso em questão. A saída completa não é fornecida pelo fato de ser muito extensa.

\subsubsection{Comparação dos Dados Obtidos Através da Simulação Computacional com os Dados Experimentais.}

Os dados documentados pelo relatório final FUMEX III para o experimento IFPE/RISOEIII (NEA-1493/17), vareta ZX115, tornam possível a realização das seguintes análises:

- Liberação de gases de físsão;

- Temperatura da região central da pastilha combustível;

- Temperatura da região central da pastilha combustível enfatizando a rampa de potência aplicada no final da vida da vareta combustível.

\subsubsection{Temperatura Central da Pastilha Combustível.}

A base de dados fornecida pelo programa FUMEX III não apresenta, para este caso, dados experimentais relacionados à distribuição das temperaturas na pastilha combustível. Entretanto, o relatório final FUMEX III (IAEA-FUMEX-III, 2013) fornece dois gráficos relativos às temperaturas na pastilha combustível: o primeiro, fornecido na Figura 5.9, mostra a temperatura na região central da pastilha combustível em função da queima e o segundo, fornecido na Figura 5.10, apresenta o comportamento da temperatura na região central da pastilha combustível levando em consideração a rampa de potência aplicada no 
final da vida da vareta combustível. Essas duas curvas foram obtidas através dos códigos computacionais empregados pelas equipes que participaram do projeto.

Através da utilização do código FRAPCON-3.4a, foram obtidos os gráficos ilustrados nas Figuras 5.11 e 5.12. O gráfico fornecido na Figura 5.11 apresenta a variação da temperatura na região central da pastilha combustível em função da queima e o gráfico fornecido na Figura 5.12 mostra a variação da temperatura da região central da vareta combustível durante a rampa de potência aplicada no final da vida da vareta combustível.

Uma primeira análise das curvas apresentadas nos gráficos das Figuras 5.9 e 5.11 mostra uma boa convergência entre os dados fornecidos pelo código FRAPCON-3.4a quando comparados aos resultados fornecidos pelos demais códigos. Entretanto, quando se realiza a comparação entre as curvas fornecidas nas Figuras 5.10 e 5.12, as quais mostram o comportamento da temperatura na região central da pastilha combustível quando a vareta é submetida a uma rampa de potência, observa-se uma discrepância relativamente grande entre o resultados fornecidos pelos códigos, chegando, em alguns pontos, a diferenças da ordem de $500{ }^{\circ} \mathrm{C}$.

Esta discrepância, provavelmente, é devida ao fato de que a rampa de potência foi aplicada no final da vida da vareta combustível, com uma queima aproximada de 40-42 $\mathrm{MWd} / \mathrm{kgU}$, condição na qual começam a ocorrer uma série de fenômenos no combustível que influenciam significativamente no comportamento térmico da pastilha, fenômenos esses que ainda não se encontram adequadamente modelados pelos códigos.

\subsubsection{Liberação de Gases de Fissão.}

O principal objetivo do experimento IFPE/RISOEIII-GE7 (NEA-1493/17) foi o de estudar o efeito que uma rampa de potência aplicada no final da vida de uma vareta combustível acarreta no processo de liberação de gases de fissão.

É de conhecimento geral que rampas de potência causam uma rápida elevação de temperatura na pastilha combustível, fato que pode ser observado na Figura 5.10. Este fato, adicionado às condições presentes na pastilha combustível com alta queima, tendem a acelerar de forma acentuada o processo de liberação de gases de fissão, fato este estudado nos itens 2.2.1.6 e 2.3.1.2 do presente trabalho. Tal fato também foi constatado no experimento realizado, e pode ser observado no gráfico fornecido na Figura 5.13, o qual apresenta uma comparação entre o resultado obtido experimentalmente para a liberação de gases de fissão com os resultados obtidos através da simulação computacional. 


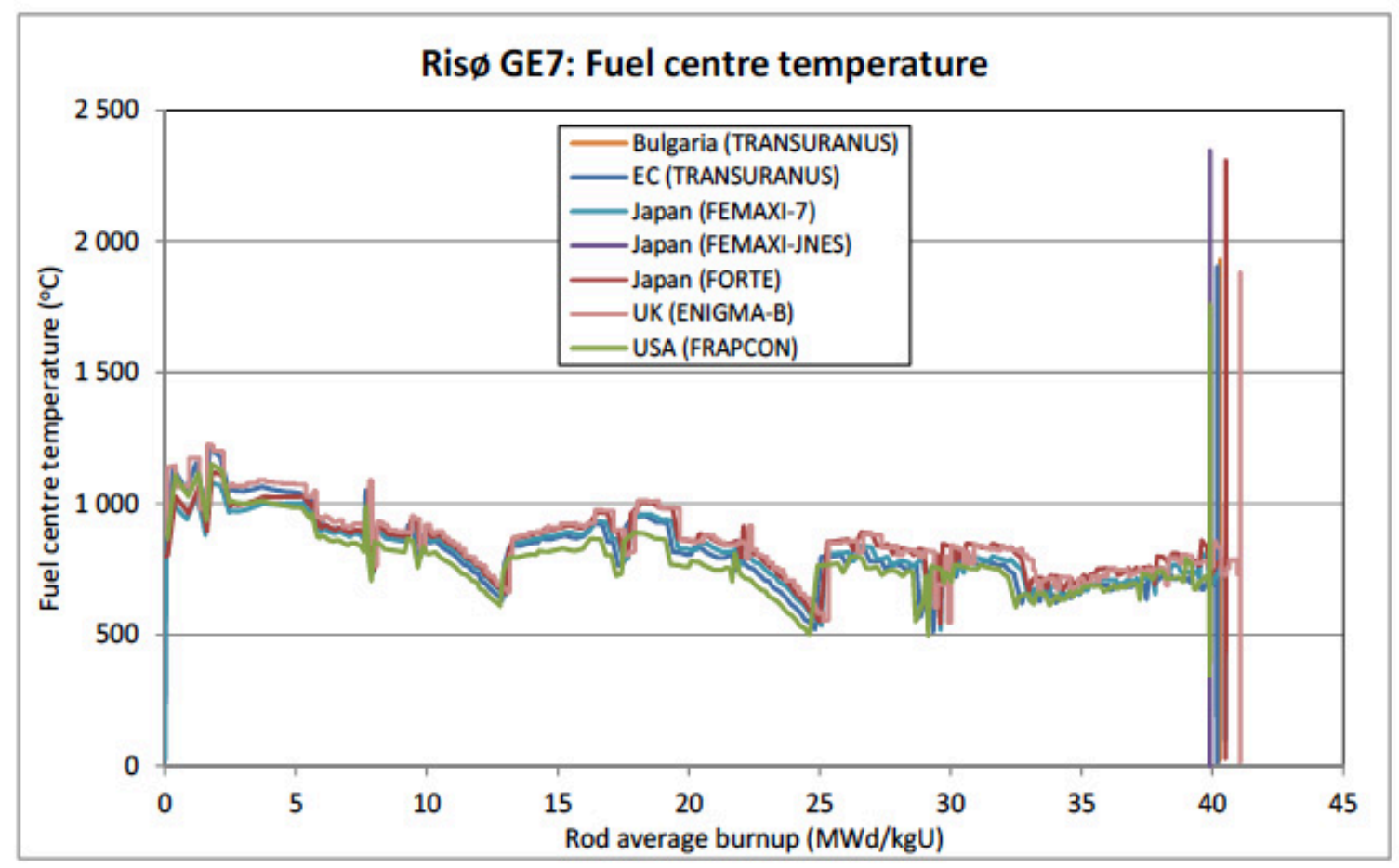

Figura 5.9 - Variação da temperatura da região central da vareta combustível em função da queima.

Fonte: Relatório Final FUMEX III.

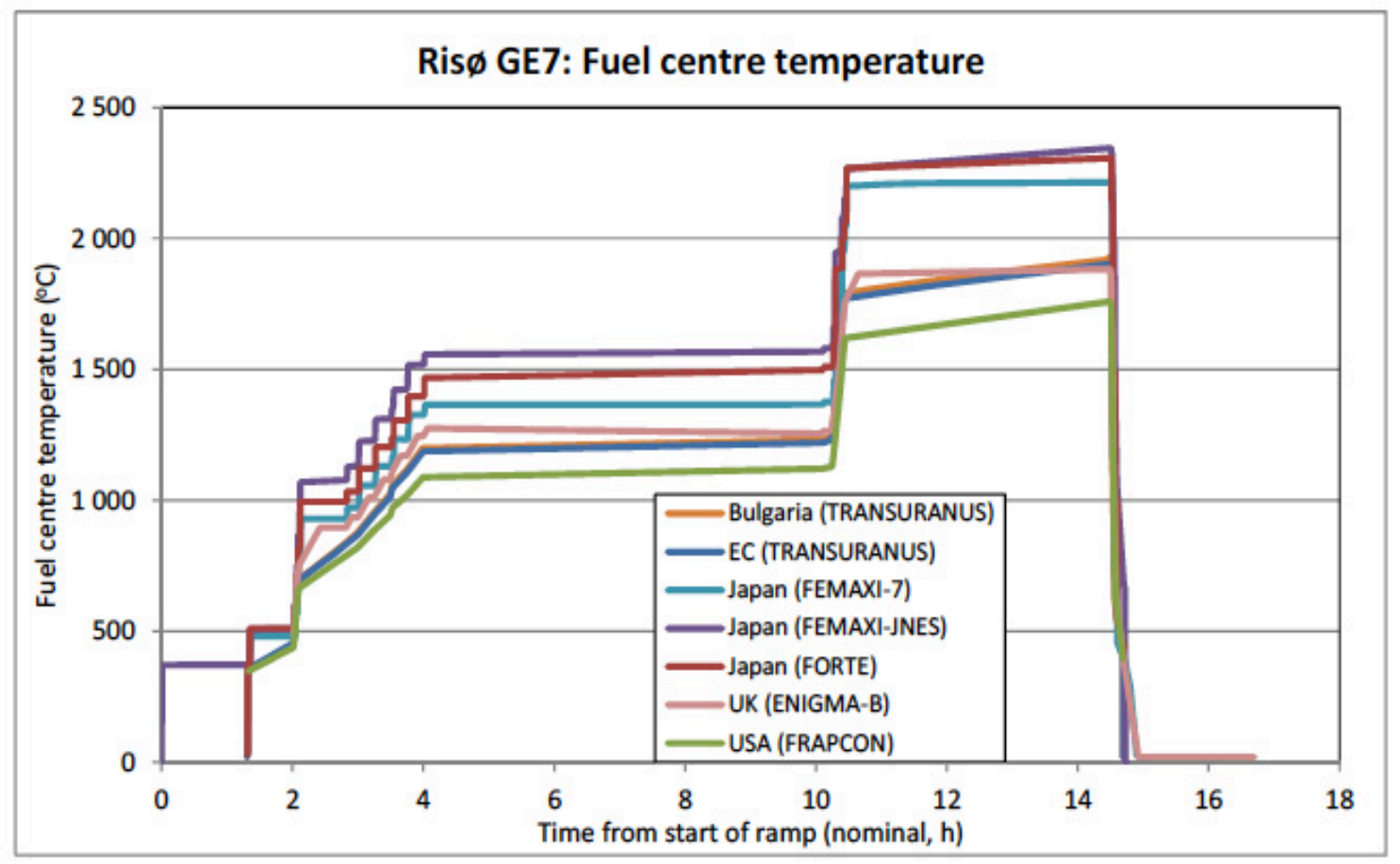

Figura 5.10 - Variação da temperatura da região central da vareta combustível durante a rampa de potência aplicada no final da vida da vareta combustível.

Fonte: Relatório Final FUMEX III. 


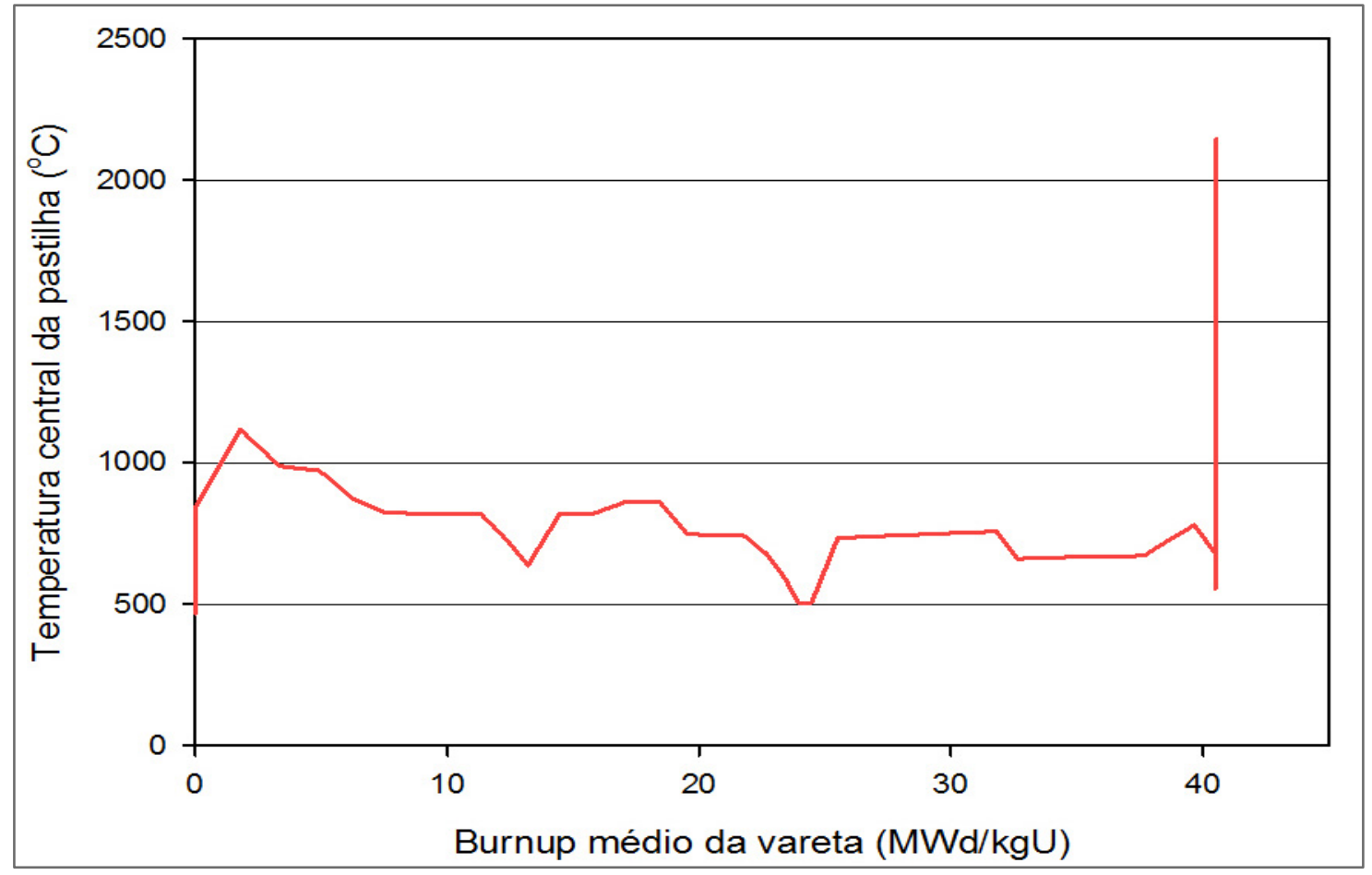

Figura 5.11 - Variação da temperatura da região central da vareta combustível em função da queima obtida pelo código FRAPCON-3.4a.

Fonte: Autor.

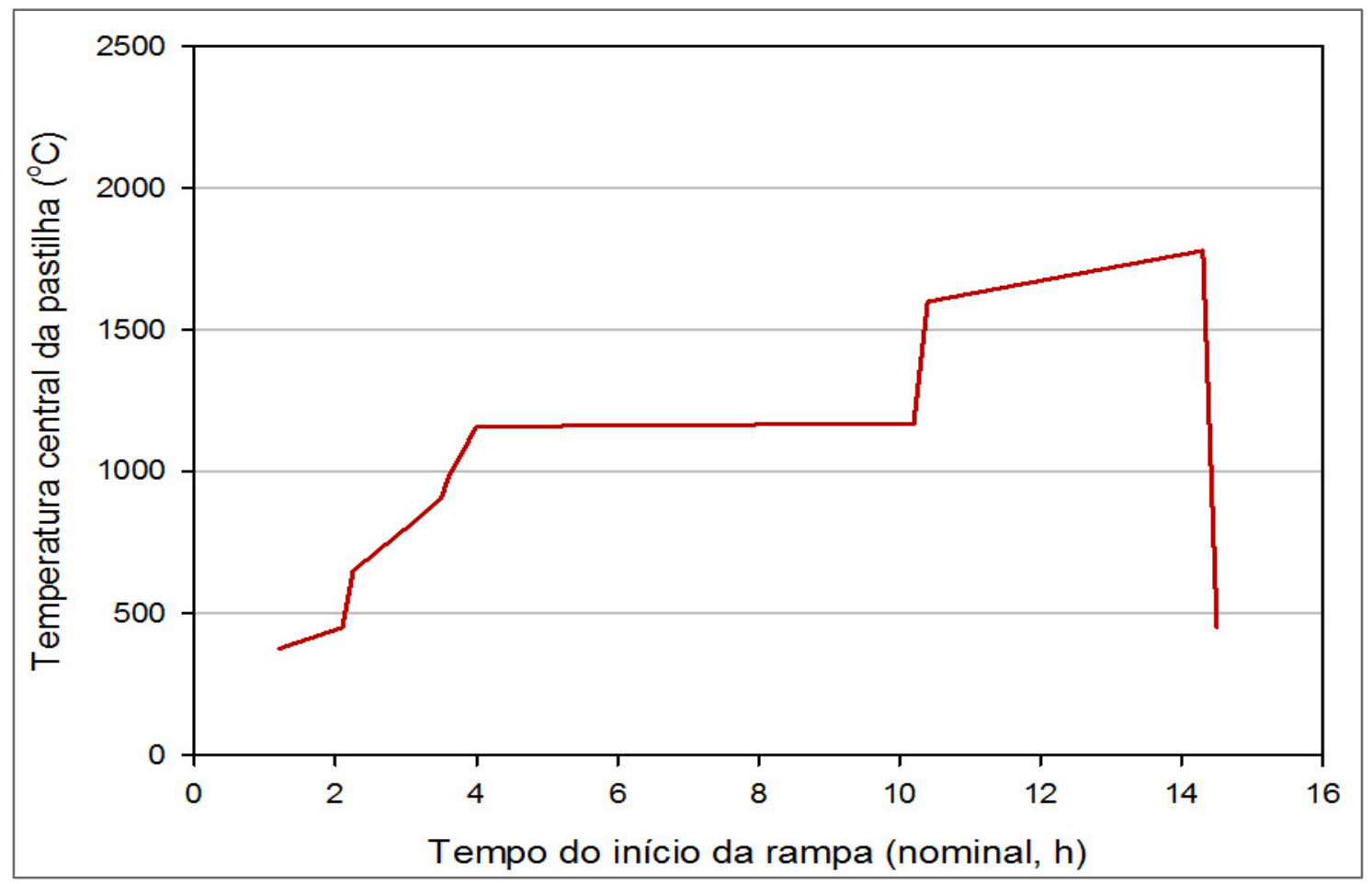

Figura 5.12 - Variação da temperatura da região central da vareta combustível durante a rampa de potência aplicada no final da vida da vareta combustível obtida pelo código FRAPCON-3.4a.

Fonte: Autor. 
Neste gráfico se pode constatar que, a partir do momento em que é aplicada a rampa de potência (queima aproximada de $40 \mathrm{MWd} / \mathrm{kgU}$ ), ocorre uma elevação acentuada na quantidade de gás liberado, atingindo um valor experimental de $14,4 \%$ do total de gás produzido.

A Figura 5.14 apresenta o gráfico com os resultados obtidos para a liberação de gás de fissão através de simulação computacional realizada com o código FRAPCON-3.4a. O resultado obtido por meio desta simulação foi de $12,8 \%$ do total de gás produzido, valor este que é cerca de $11 \%$ menor que o resultado obtido experimentalmente $(14,4 \%)$. Esta discrepância se deve, muito provavelmente, à complexidade dos fenômenos envolvidos e a dificuldade dos modelos empregados pelo código em representar esses fenômenos.

\subsection{Comparação dos Dados Fornecidos Pelo Programa FRAPTRAN-1.4 com os Dados Fornecidos pelo Experimento IFPE/NSRR-FK1 NEA-1724/01.}

O experimento IFPE/NSRR NEA-1724/01 foi realizado no período de 1984 a 1997 e teve por finalidade investigar o comportamento do combustível quando submetido a acidente inicializado por reatividade (RIA). Em sua fase final, este experimento analisou o comportamento de três varetas combustíveis utilizadas em reatores BWR, denominadas FK-1, FK-2 e FK-3. Nesta análise serão utilizados os dados obtidos através do experimento realizado com a vareta combustível FK-1.

O experimento IFPE/NSRR-FK1 NEA-1724/01 foi realizado em duas etapas: na primeira etapa, foram utilizados elementos combustíveis 8x8 BJ-STEP I, da unidade 3 da Central Nuclear de Fukushima Daiichi, que foram irradiados em condições de regime permanente até uma queima de 41-45 $\mathrm{MWd} / \mathrm{kgU}$. Na segunda etapa, a vareta FK-1 foi refabricada a partir das varetas utilizadas no elemento combustível irradiado no reator de Fukushima e transferida para o Reator de Pesquisa de Segurança Nuclear (Nuclear Safety Research Reactor - NSRR), sendo submetida a pulsos de entalpia da ordem de 293-607 $\mathrm{J} / \mathrm{g}$, por períodos de $4,4 \mathrm{~ms}$, com a finalidade de simular acidentes inicializados por reatividade (RIA).

A Tabela 5.3 apresenta as características das varetas utilizadas na primeira etapa do experimento IFPE/NSRR-FK1 NEA-1724/01 e a Tabela 5.4 apresenta o resumo dos resultados obtidos após os pulsos RIA para a vareta combustível FK-1. 


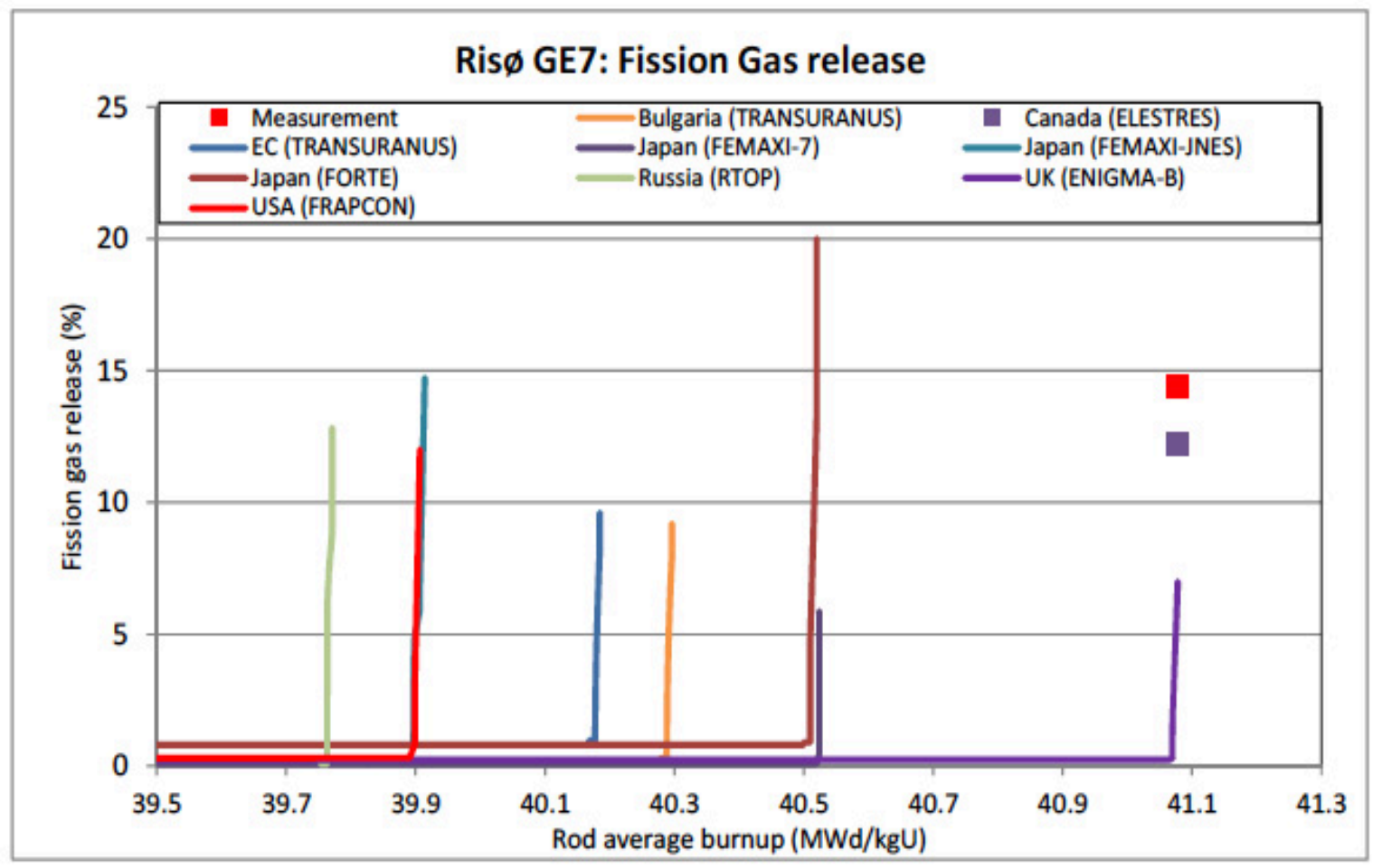

Figura 5.13 - Valor experimental e predições dos códigos computacionais para a liberação de gás de fissão.

Fonte: Relatório Final FUMEX III.

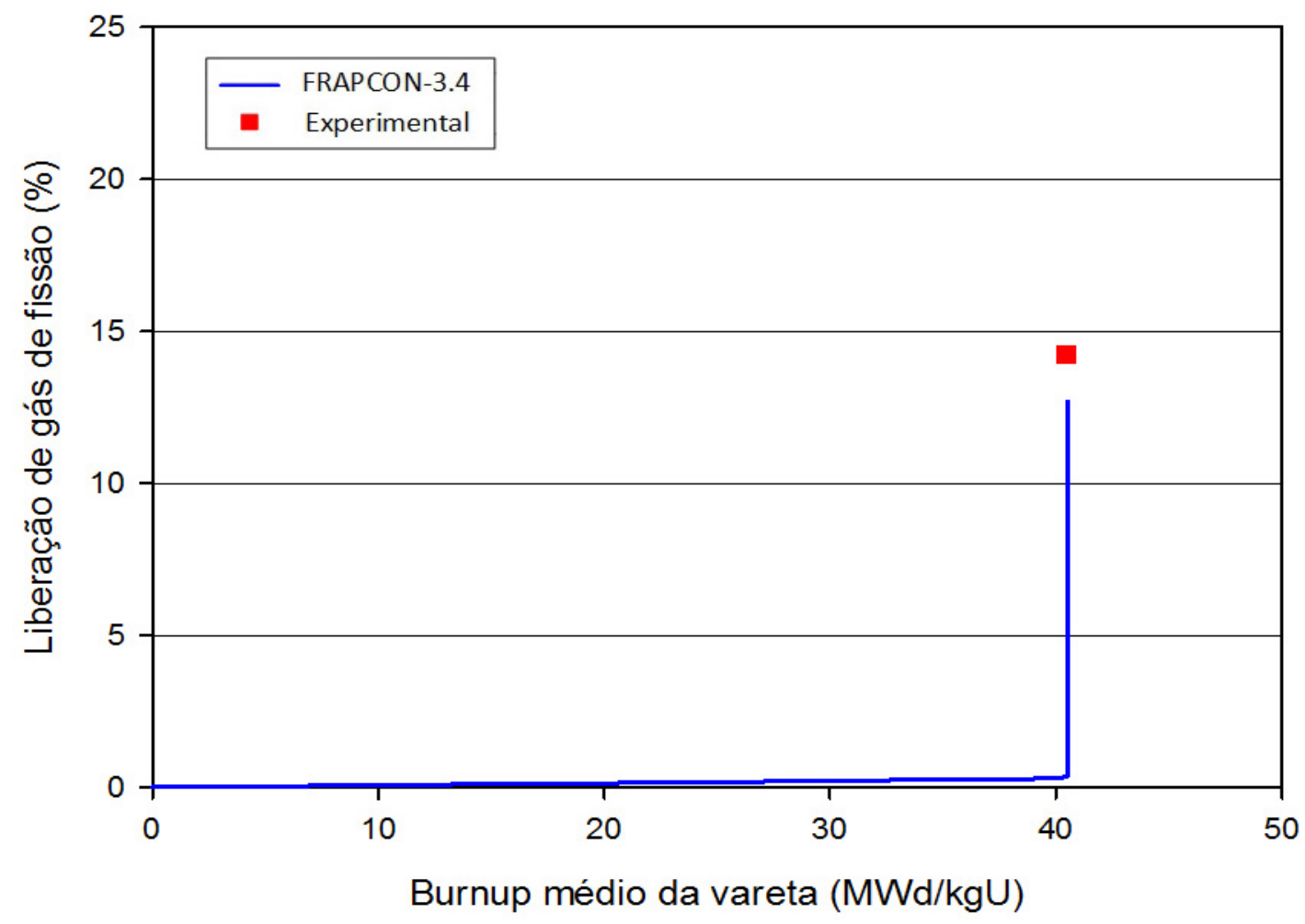

Figura 5.14 - Valor experimental e predição do código FRAPCON-3.4a para a liberação de gás de fissão.

Fonte: Autor. 
Tabela 5.3 - Características de projeto e condições de pré-pulsos para RIA da vareta combustível utilizada no experimento FK-1.

\begin{tabular}{l|l}
\hline Tipo de elemento combustível & $8 x 8 \mathrm{BJ}$ \\
Material do revestimento & Zircaloy-2 Recristalizado \\
Diâmetro externo do revestimento $(\mathrm{mm})$ & 12,3 (nominal) \\
Espessura da parede do revestimento $(\mathrm{mm})$ & 0,86 (nominal) \\
Densidade do combustível $(\% \mathrm{DT})$ & 95 (nominal) \\
Enriquecimento $\left(\% \mathrm{U}^{235}\right)$ & 3,9 (nominal) \\
Gás de enchimento $(\mathrm{MPa})$ & He:0,3 (nominal) \\
\hline Queima (pré-pulso RIA) $(\mathrm{MWd} / \mathrm{kgU})$ & 45 \\
& 16,3 (médio) \\
Espessura da camada de óxido $(\mu \mathrm{m})$ & 21,5 (máximo) \\
\hline Absorção de hidrogênio $(\mathrm{ppm})$ & 45 a 59 \\
Fluência do revestimento $(\mu \mathrm{m})$ & 8 \\
Gap radial inicial $(\mu \mathrm{m})$ & 120 \\
\hline Liberação de gás de fissão $(\%)$ & 1.5 \\
Pressão do gás (final da vida) $(\mathrm{MPa})$ & 0,42 \\
Pico da taxa de calor linear $(\mathrm{W} / \mathrm{cm})$ & 228 \\
\hline
\end{tabular}

Fonte: Base da Dados FUMEX-III - IAEA.

Tabela 5.4 - Condições de teste e resumo dos resultados após pulsos para RIA da vareta combustível utilizada no teste FK-1.

\begin{tabular}{l|l}
\hline Queima (MWd/kgU) & 45 \\
Entalpia de pico no combustível $(\mathrm{J} / \mathrm{g})$ & 544 \\
Temperatura na superfície do combustível $\left({ }^{\circ} \mathrm{C}\right)$ & $180\left(\mathrm{n}^{\mathrm{o}} 1\right), 350\left(\mathrm{n}^{\mathrm{o}} 2\right)$ \\
Alongamento da coluna de pastilhas $(\%)$ & 1,4 \\
Deformação axial do revestimento $(\%)$ & 1,1 \\
Pressão interna da vareta $(\mathrm{MPa})$ & 1,9 \\
Liberação de gás de fissão $(\%)$ & 8,2 \\
\hline
\end{tabular}

Fonte: Base da Dados FUMEX-III - IAEA.

\subsubsection{Simulação computacional da vareta combustível utilizada no experimento IFPE/NSRR-FK1 NEA-1724/01 através dos códigos FRAPCON-3.4a e FRAPTRAN-1.4.}

Para realizar a simulação do comportamento da vareta combustível utilizada no experimento IFPE/NSRR-FK1 NEA-1724/01 foram empregados os programas 
computacionais FRAPCON-3.4a e FRAPTRAN-1.4. O programa FRAPCON-3.4a foi utilizado com a finalidade de se obter comportamento da vareta combustível durante a irradiação inicial, realizada em regime permanente, e também para gerar o arquivo de dados de entrada para o código FRAPTRAN-1.4, que foi utilizado para a análise do comportamento da vareta sob a ação de um transiente, simulando um acidente inicializado por reatividade (RIA).

Como pode ser observado na Figura 5.15, o processo de simulação tem início através da execução do programa FRAPCON-3.4a, o qual utiliza o arquivo de dados de entrada FK1_BASE.in. Este arquivo fornece as condições para que o código realize a simulação do comportamento da vareta combustível operando em regime permanente, e gere os arquivos FK1_BASE.out, com os resultados desta análise, e RESTART.FK1, com os dados que serão necessários para a análise de transiente que será realizada com o código FRAPTRAN-1.4.

Finalizada a execução do programa FRAPCON-3.4a, inicia-se a execução do código FRAPTRAN-1.4, o qual utilizada o arquivo de dados de entrada RIA_FK1.in que, por sua vez, aciona o arquivo RESTART.FK1 com os dados obtidos por meio do programa FRAPCON-3.4a. Finalizada a execução do código FRAPTRAN-1.4, é gerado o arquivo de saída RIA_FK1.out, o qual fornece os resultados que serão comparados com os dados obtidos experimentalmente.

Os arquivos de entrada utilizados para a execução dos programas computacionais FRAPCON-3.4a e FRAPTAN-1.4 para o caso em questão são fornecidos no Anexo 3 deste trabalho.

\subsubsection{Comparação dos Dados Obtidos Através da Simulação Computacional com os Dados Experimentais.}

Os dados documentados pelo relatório final FUMEX III para o experimento IFPE/NSRR-FK1 NEA-1724/01 tornam possível a realização das seguintes análises:

- Temperatura da região central da pastilha combustível durante o pulso RIA;

- Pressão interna da vareta combustível durante o pulso RIA;

- Alongamento da coluna de pastilhas combustíveis durante pulso RIA;

- Alongamento do revestimento durante pulso RIA. 


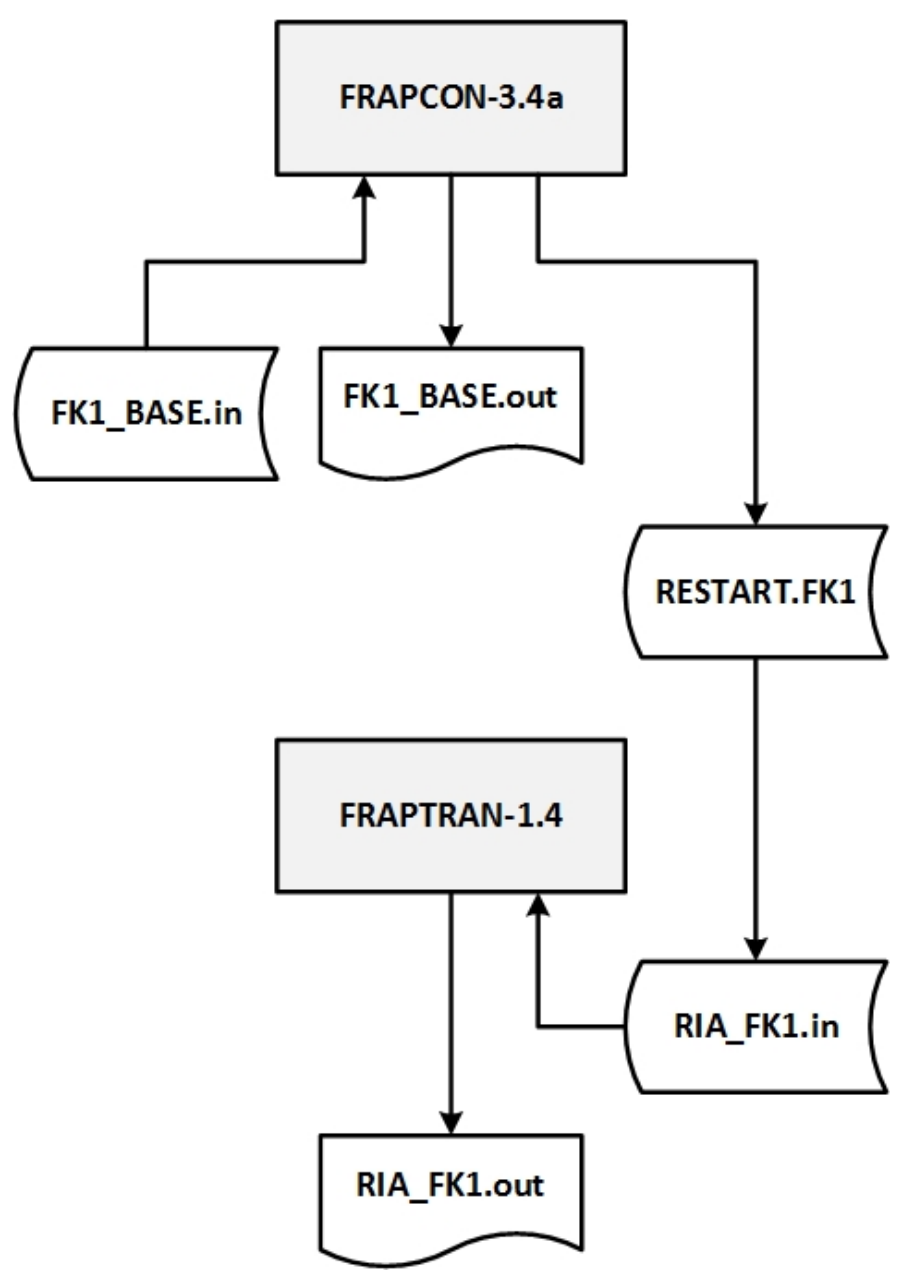

Figura 5.15 - Processo de simulação utilizando-se os códigos FRAPCON-3.4a e FRAPTRAN-1.4.

Fonte: Autor.

\subsubsection{Temperatura Central da Pastilha Combustível.}

Como nos casos anteriores, a base de dados fornecida pelo programa FUMEX III não apresenta, para este experimento, dados relacionados à distribuição das temperaturas na pastilha combustível. Entretanto, o relatório final FUMEX III (IAEA-FUMEX-III, 2013) fornece, para o experimento em questão, um gráfico com a temperatura na região central da pastilha combustível em função do tempo, durante o período do pulso para simulação de RIA. Essas temperaturas foram obtidas através de simulação computacional realizada pelos diversos códigos que participaram do projeto e se encontram fornecidas na Figura 5.16. Nesta figura pode-se observar que existe uma boa concordância entre as temperaturas fornecidas pelos códigos FRAPTRAN e TRANSURANUS e uma 
discrepância significativa entre as temperaturas fornecidas por esses códigos quando comparadas aos resultados fornecidos pelo código FAIR.

A Figura 5.17 apresenta o resultado obtido para a temperatura na região central da pastilha combustível em função do tempo decorrido desde o início do pulso para a simulação de RIA utilizando-se o código FRAPTRAN-1.4. Comparando-se as Figuras 5.16 e 5.17 pode-se observar que existe uma boa convergência dos dados fornecidos pelo relatório final FUMEX-III com os dados obtidos através da simulação computacional realizada neste trabalho.

\subsubsection{Pressão interna da vareta combustível.}

A Figura 5.18 mostra o resultado obtido para a pressão interna na vareta combustível FK-1 durante o período de tempo de aplicação do pulso para simulação de RIA, por intermédio dos códigos utilizados pelas equipes que participaram do programa FUMEX-III e realizaram a análise deste experimento.

Nesta figura se pode observar a existência de uma divergência apreciável entre as pressões fornecidas pelos diversos códigos quando comparadas aos resultado obtido experimentalmente. Essas divergências ocorrem, provavelmente, devido à variação da quantidade de gás de fissão liberada calculada pelos modelos utilizados pelos códigos, que varia significativamente de código para código, conforme comentado no Item (5.2.2)

A Figura 5.19 apresenta o resultado obtido através da simulação realizada pelos códigos FRAPCON-3.4a e FRAPTRAN-1.4 para o experimento em questão. A comparação das Figuras 5.18 e 5.19 mostra que o resultado obtido pela simulação realizada neste trabalho possui uma discrepância acentuada com relação aos resultados obtidos pela equipe da Bélgica que também utilizou o código FRAPTRAN. Após a realização de diversas revisões dos dados utilizados para simulação do experimento em questão, não foi encontrado qualquer inconsistência nos dados de entrada. Como o relatório FUMEX-III não fornece os dados de entrada utilizados pela equipe Belga para tal simulação, nem a versão dos códigos FRAPCON e FRAPTRAN que foram empregados, não foi possível realizar uma análise mais aprofundada à respeito de tal discrepância. 


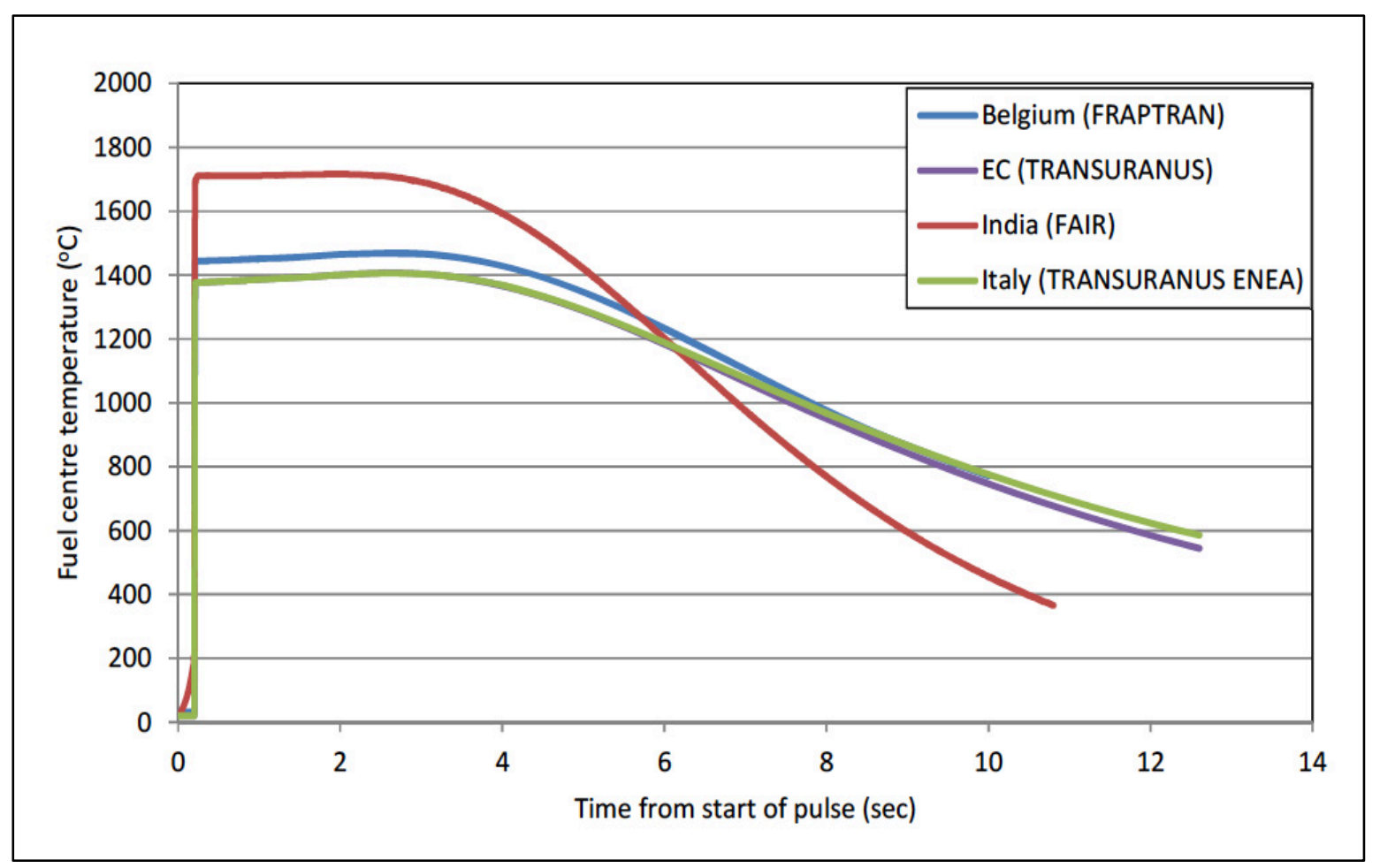

Figura 5.16 - Temperatura na região central da pastilha combustível durante a aplicação do pulso para simulação de RIA.

Fonte: Relatório Final FUMEX III.

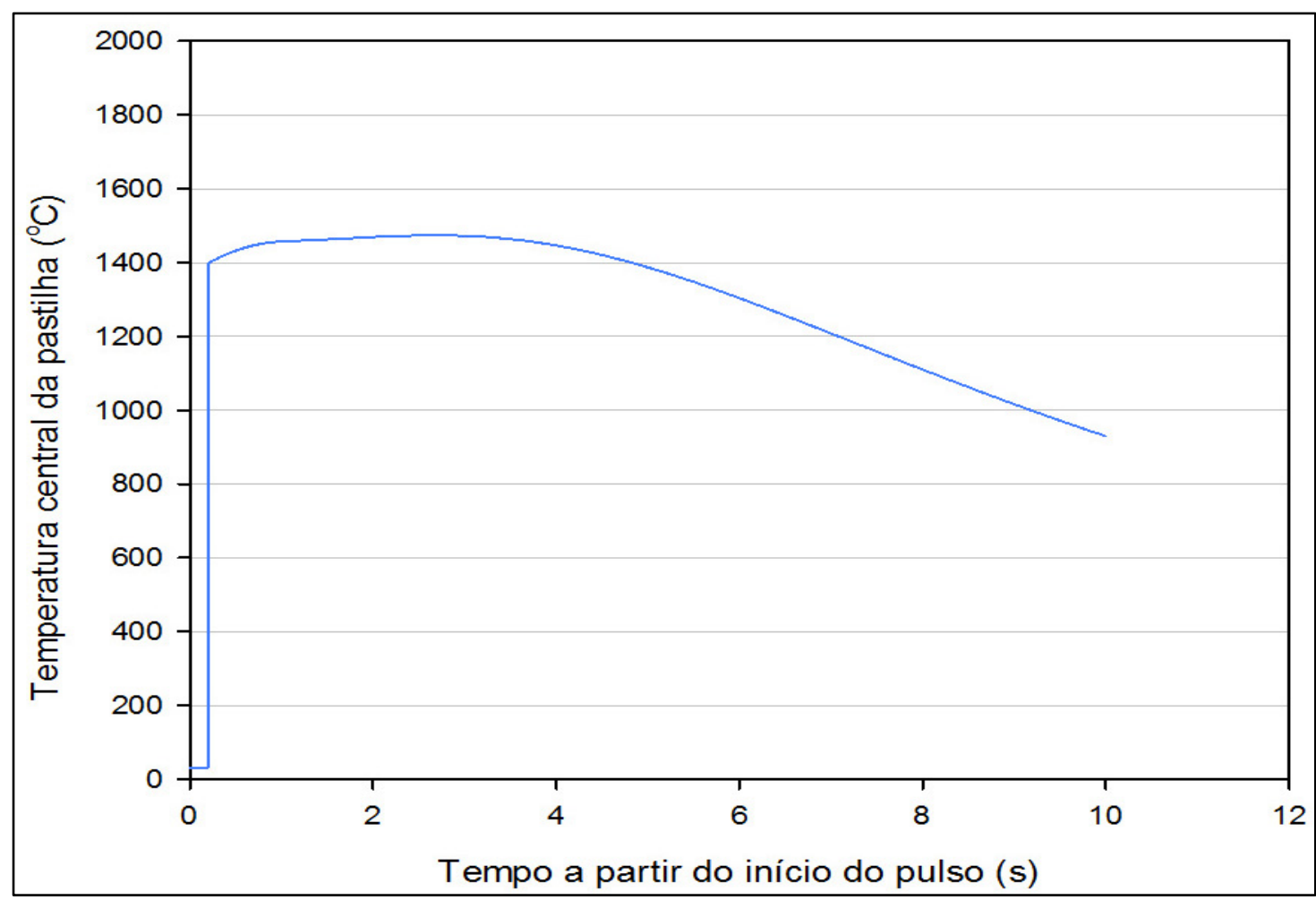

Figura 5.17 - Variação da temperatura da região central da vareta combustível em função do tempo decorrido do pulso fornecida pelo código FRATRAN-1.4.

Fonte: Autor. 


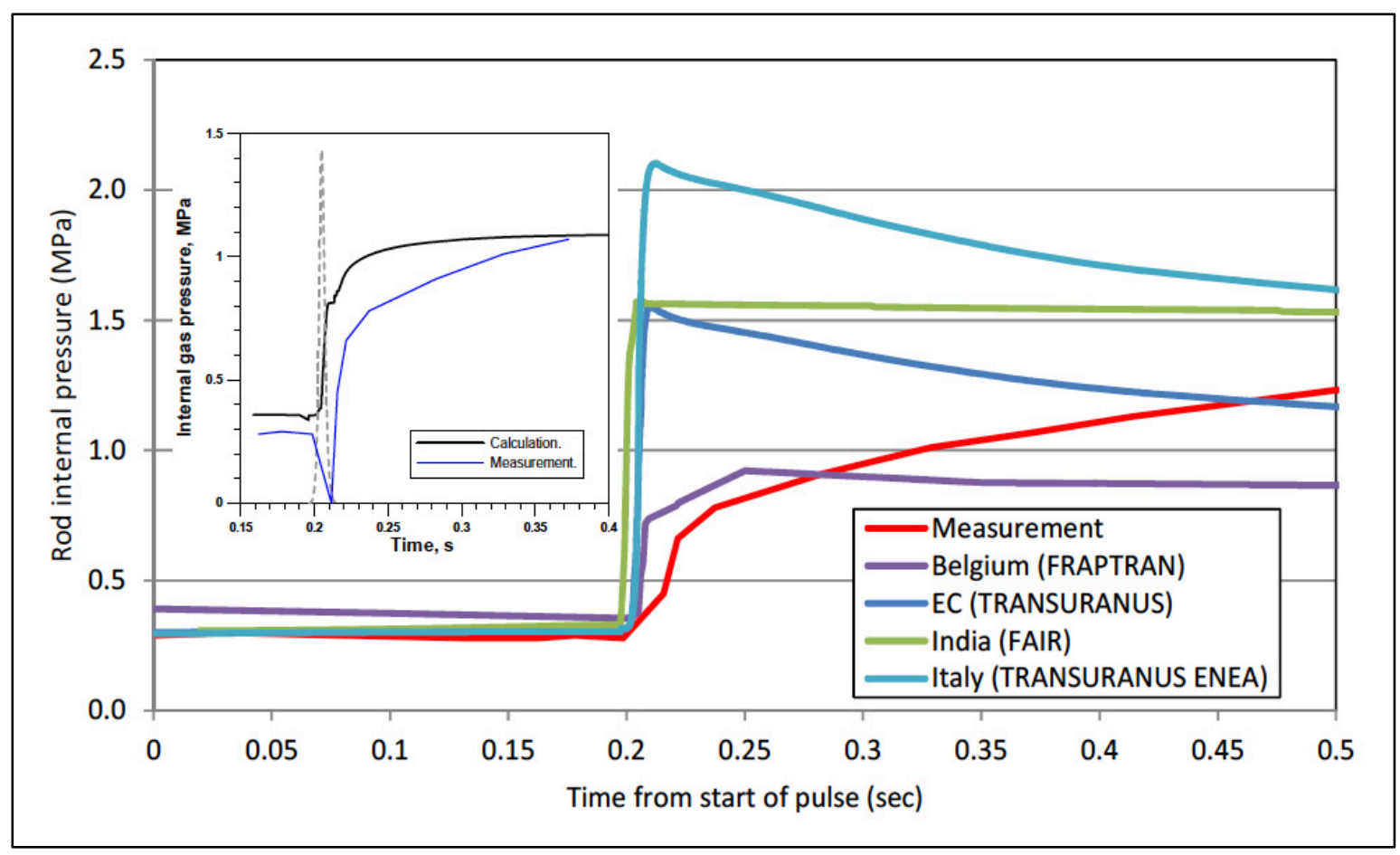

Figura 5.18 - Predições dos códigos computacionais para a pressão interna da vareta combustível FK-1 em função do tempo decorrido da aplicação do pulso para simulação de RIA.

Fonte: Relatório Final FUMEX III.

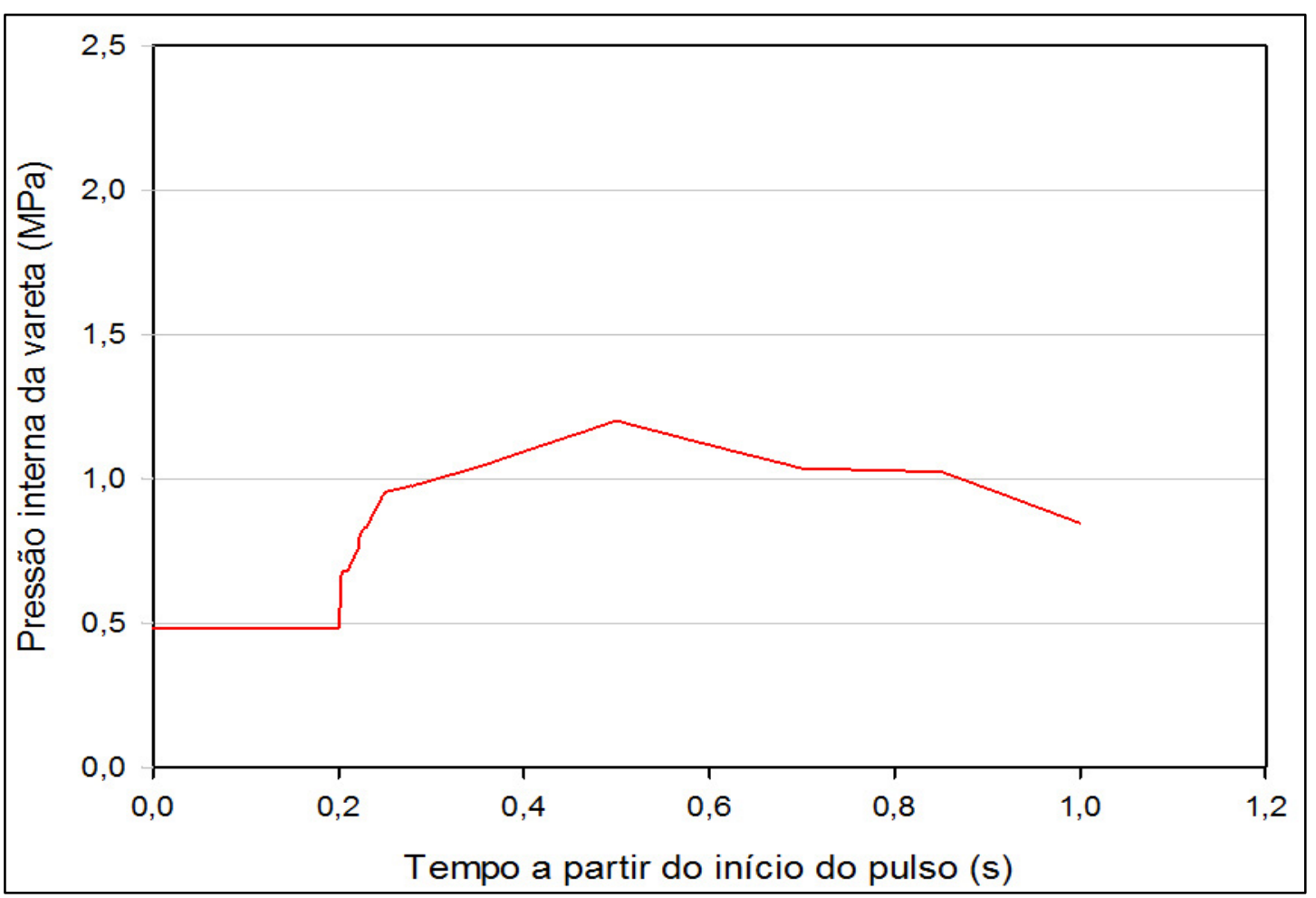

Figura 5.19 - Variação da pressão interna da vareta combustível FK-1 em função do tempo decorrido do pulso para simulação de RIA fornecida pelo código FRAPTRAN-1.4.

Fonte: Autor. 


\subsubsection{Alongamento da coluna de pastilhas combustíveis.}

A Figura 5.20 mostra o resultado obtido para o alongamento da coluna de pastilhas combustíveis da vareta combustível FK-1 durante o período de tempo de aplicação do pulso para simulação de RIA, através dos códigos utilizados pelas equipes que participaram do programa FUMEX-III e realizaram a análise deste experimento.

Nesta figura se pode observar que existe uma concordância aceitável entre os resultados fornecidos pelos códigos TRANSURANUS, RANN-Sliding e FRAPTRAN quando comparado aos dados obtidos experimentalmente. Já os códigos RANNS-Bonding e TRANSURANUS ENEA possuem uma discrepância significativa quando comparados aos dados experimentais.

A Figura 5.21 ilustra o resultado obtido para o alongamento da coluna de pastilhas combustíveis por meio da simulação computacional realizada neste trabalho através da utilização do código computacional FRAPTRAN-1.4. Comparado os resultados obtidos nesta simulação com os resultados ilustrados na Figura 5.20, podemos observar que a mesma se encontra de acordo com o resultado obtido pela equipe Belga que também utiliza o código FRAPTRAN.

\subsubsection{Alongamento do revestimento.}

A Figura 5.22 apresenta os resultados obtidos para o alongamento do revestimento da vareta combustível FK-1 durante o período de tempo de aplicação do pulso para simulação de RIA, através dos códigos utilizados pelas equipes que participaram do programa FUMEX-III e realizaram a análise deste experimento.

Nesta figura se pode observar que existe uma concordância aceitável entre o resultado fornecido pelos códigos TRANSURANUS, RANN-Bonding e FRAPTRAN quando comparado aos dados obtidos experimentalmente. Já os códigos RANNS-Sliding e TRANSURANUS ENEA possuem uma discrepância significativa quando comparados aos dados experimentais.

A Figura 5.23 ilustra o resultado obtido para o alongamento do revestimento por meio da simulação computacional realizada neste trabalho através da utilização do código computacional FRAPTRAN-1.4. Comparado os resultados obtidos nesta simulação com os resultados ilustrados na Figura 5.22, podemos observar que a mesma se encontra de acordo com o resultado obtido pela equipe Belga que também utiliza o código FRAPTRAN. 


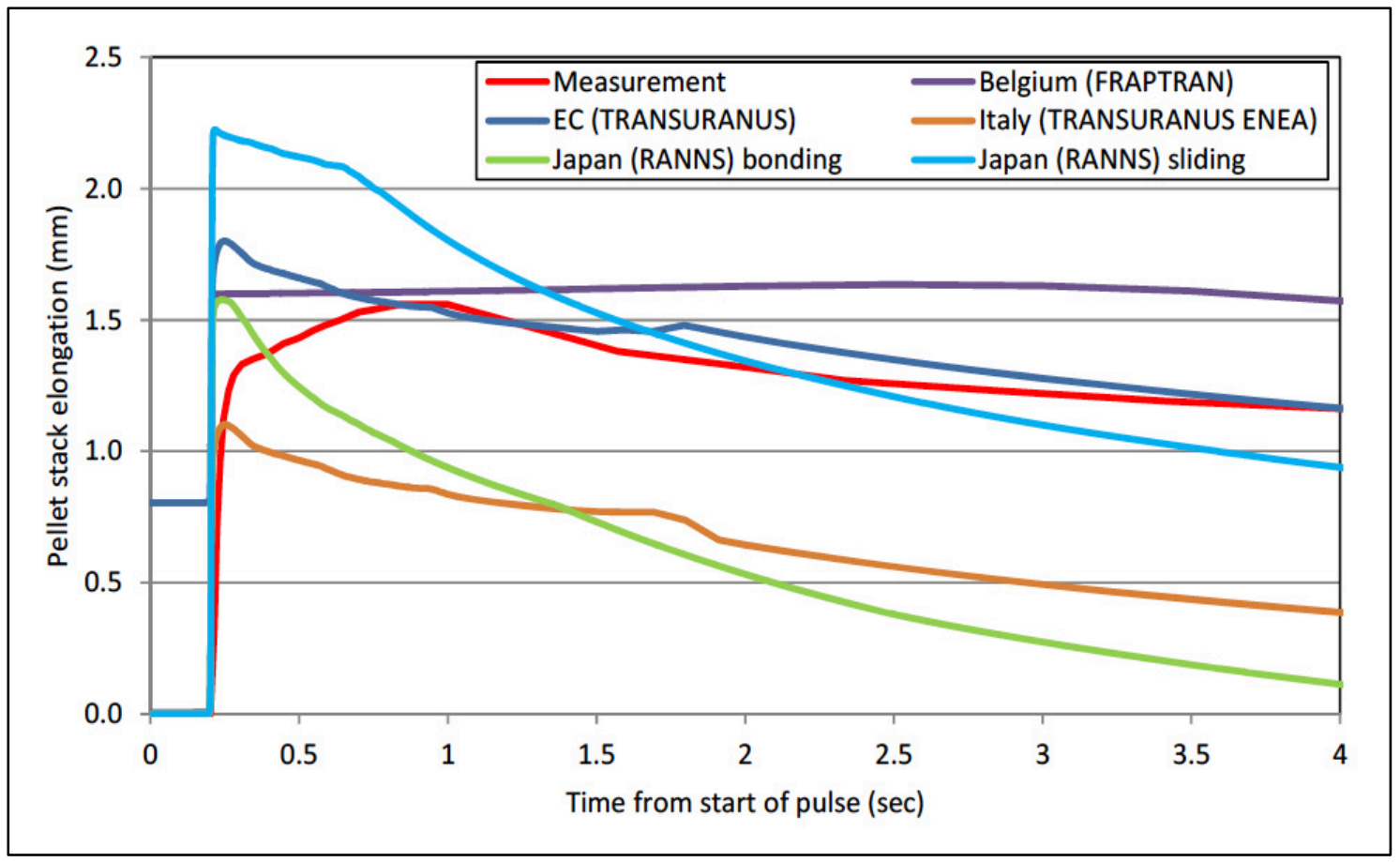

Figura 5.20 - Predições dos códigos computacionais para o alongamento da coluna de pastilhas combustíveis da vareta FK-1 em função do tempo decorrido da aplicação do pulso para simulação de RIA.

Fonte: Relatório Final FUMEX III.

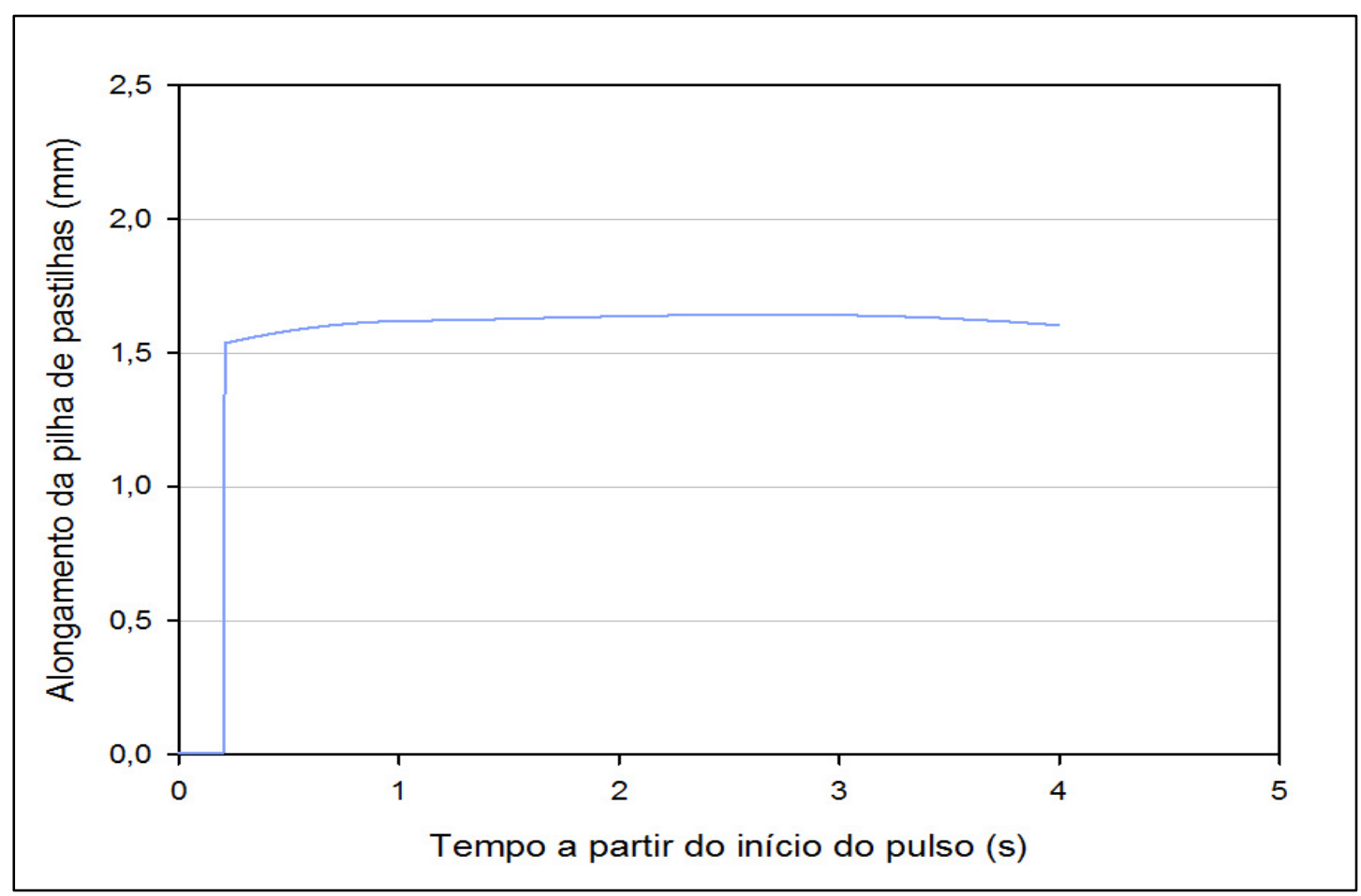

Figura 5.21 - Alongamento da coluna de pastilhas combustíveis da vareta combustível FK-1 em função do tempo decorrido do pulso para simulação de RIA fornecida pelo código FRAPTRAN-1.4.

Fonte: Autor. 


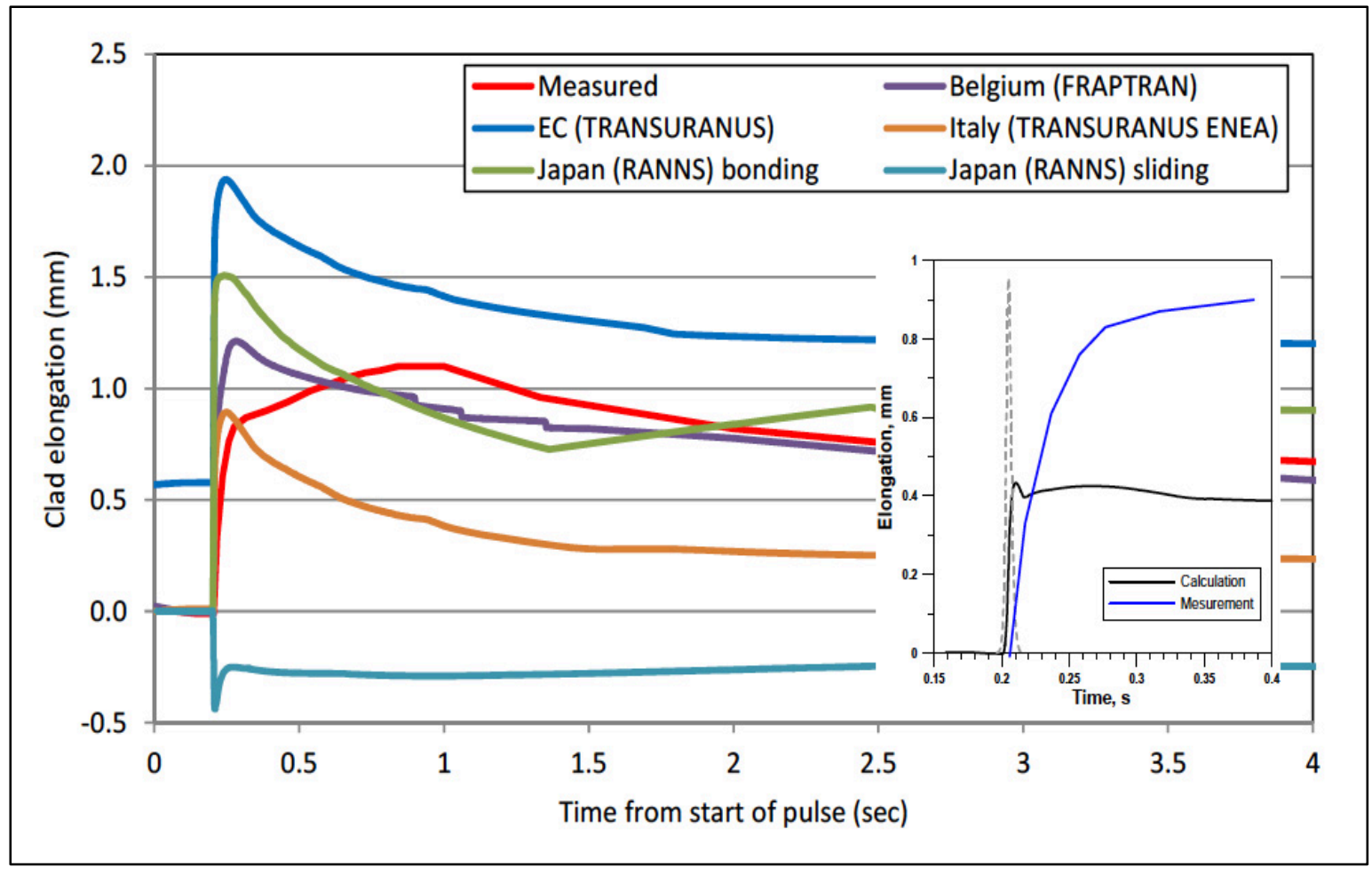

Figura 5.22 - Predições dos códigos computacionais para o alongamento do revestimento da vareta FK-1 em função do tempo decorrido da aplicação do pulso para simulação de RIA.

Fonte: Relatório Final FUMEX III.

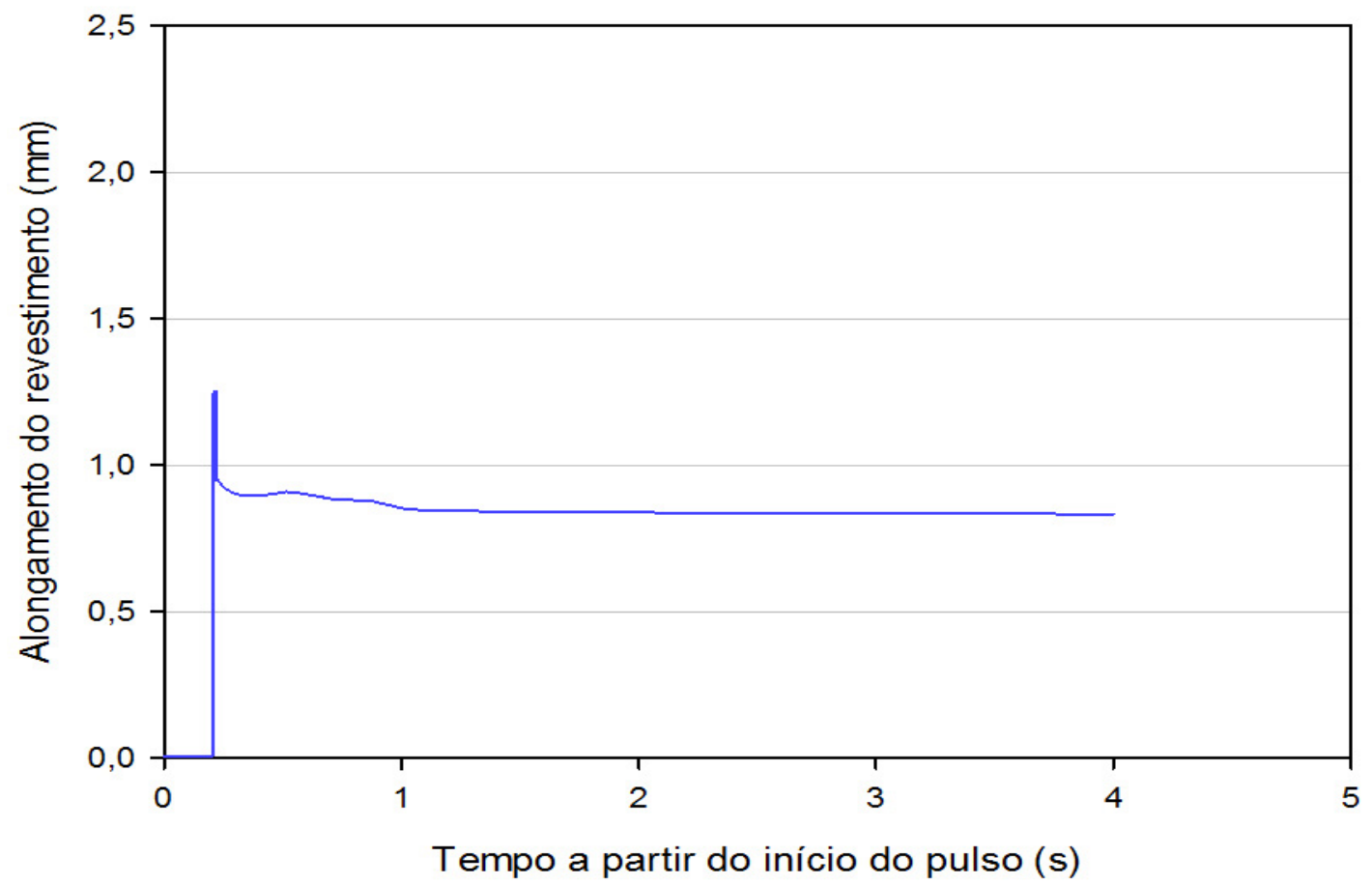

Figura 5.23 - Alongamento do revestimento da vareta combustível FK-1 em função do tempo decorrido do pulso para simulação de RIA fornecida pelo código FRAPTRAN-1.4.

Fonte: Autor. 


\section{CONCLUSÃO}

Através do desenvolvimento deste trabalho, foi possível obter uma boa compreensão dos diversos fenômenos que se manifestam durante a operação de varetas combustíveis utilizadas em reatores de água leve (LWR). Também foi possível compreender as estruturas lógicas dos programas computacionais FRAPCON e FRAPTRAN, além de se obter o conhecimento necessário para a elaboração dos respectivos arquivos de dados de entrada e a execução dos programas.

Com relação aos resultados fornecidos por esses programas para os casos analisados, pode-se constatar que os mesmos encontram-se dentro do esperado quando comparados aos dados fornecidos pelo relatório final FUMEX-III.

Em condições operacionais de regime permanente, foram analisados dois casos: US-PWR-16x16 e RISOIII-GE7. Em ambos os casos, o programa computacional FRAPCON-3.4a apresentou bons resultados com relação à temperatura da pastilha combustível em condições operacionais de baixa e de alta queima. Com relação aos resultados fornecidos envolvendo a liberação de gases de fissão, foram encontrados desvios significativos entre os valores fornecidos pelo código quando comparados com os dados obtidos experimentalmente, principalmente em condições de altas queimas. Muito provavelmente, este desvio ocorreu devido à alta complexidade dos fenômenos envolvidos no processo de liberação de gases de fissão, especialmente quando o combustível se encontra submetido a altas queimas, condição na qual ocorre o processo de reestruturação da pastilha combustível que afeta diretamente os mecanismos de liberação de gases de fissão.

No que se refere aos resultados fornecidos pelo programa FRAPCON-3.4a para a fluência do revestimento, volume livre e pressão interna no final da vida operacional da vareta combustível (caso US-PWR-16x16), também foram encontrados resultados consistentes com o dados experimentais.

No que se refere às condições operacionais envolvendo transientes, foi realizada uma única análise considerando um acidente inicializado por reatividade (RIA) - caso NSRR-FK1. Para a análise deste caso foram utilizados em conjunto, os códigos FRACON3.4a e FRAPTRAN-1.4.

As análises realizadas no caso NSRR-FK1 envolveram a determinação da temperatura na pastilha combustível, pressão interna da vareta combustível, alongamento da coluna de pastilhas combustíveis e alongamento do revestimento. Todas essas análises forneceram resultados consistentes quando confrontados aos dados obtidos de modo experimental. 
Um ponto importante a ser ressaltado nas análises realizadas através do emprego dos programas computacionais FRAPCON e FRAPTRAN é que, em geral, os resultados fornecidos por esses códigos ou se encontram próximos aos dados experimentais ou são um pouco superiores a estes, o que mostra que os modelos empregados pelos códigos são conservativos. Este fato é de grande importância para a validação do projeto de varetas combustíveis.

Com relação ao caso NSRR-FK1, uma única discrepância significativa foi observada entre os dados fornecidos pelo relatório FUMEX-III quando comparados aos resultados obtidos pelas simulações realizadas neste trabalho. Tal discrepância refere-se à curva relativa à variação da pressão interna da vareta combustível obtida na simulação realizada com o programa FRAPCON pela Bélgica e na realizada neste trabalho. Provavelmente, tal discrepância se deve ao uso de diferentes versões do programa computacional FRAPCON, que utilizam modelos diferentes para a determinação da quantidade de gás de fissão liberado, o que impacta diretamente no cálculo da pressão interna da vareta combustível.

Finalmente, dentro do escopo proposto pelo presente trabalho, que era o de adquirir o conhecimento necessário para se utilizar os programas computacionais FRAPCON-3.4a e FRAPTRAN-1.4, além de executar alguns casos visando analisar a consistência dos resultados obtidos, conclui-se que o presente trabalho atingiu de forma consistente tal objetivo.

Recomenda-se para trabalhos futuros uma análise mais detalhada dos modelos que simulam o comportamento das pastilhas combustíveis de dióxido de urânio $\left(\mathrm{UO}_{2}\right)$ da vareta combustível à altas queimas nos reatores a água leve pressurizada. Entre esses modelos incluem-se a formação da microestrutura do $\mathrm{UO}_{2}$ à altas queimas, a reestruturação do combustível, a porosidade no material reestruturado, a liberação de gases de fissão atérmica para o material reestruturado, a liberação de gases de fissão ativada termicamente, incluindo os modelos de liberação de gases, crescimento do grão e a liberação dos gases que ocorrem devido ao crescimento do grão. Deverão ser também avaliados os modelos para a condutividade térmica do $\mathrm{UO}_{2}$ a altas queimas e modelos para o comportamento do tubo de revestimento com ligas de zircônio, incluindo a corrosão do vários tipos de revestimento utilizados, a fragilização por hidrogênio e as propriedades mecânicas à altas queimas. A partir dessa análise, será possível avaliar com maior consistência os resultados obtidos da simulação da vareta combustível em condições de altas queimas com os dados experimentais obtidos e divulgados para esta vareta no programa FUMEX-III. 


\section{REFERÊNCIAS BIBLIOGRÁFICAS}

ADAMSON, R.; GARZAROLli, F.; COX, B.; STRASSER, A.; RUDLING P., "Corrosion Mechanisms in Zirconium Alloys." ZIRAT 12 - Special Topic Report. Advanced Nuclear Technology International, 2007. 45p.

ADAMSON, R.; GARZAROLli, F.; COX, B.; STRASSER, A.; RUDLING P., "High Burnup Fuel Issues.” ZIRAT 8 - Special Topic Report. Advanced Nuclear Technology International, 2007. 222p.

ADAMSON, R. et al., "Pellet-Cladding Interaction (PCI and PCMI)." ZIRAT 6 - Special Topic Report. Advanced Nuclear Technology International, 2006. 42p.

BAHL, J. K.; SAH, D. N.; CHATTERJEE, S., "Post-Irradiation Examination of Fuel Elements of Tarapur Atomic Power Station.” International Nuclear Information System. BARC Report. BARC-1014, 1979. 49p.

BERNA, G. A.; LANNING, D. D.; RAUSCH, W. N. "FRAPCON-2 Developmental Assessment.” NUREG/CR-1949. PNL-3849. 1981. 144p.

CHUBB, W.; HOTT, A. C.; ARGALL, B. M.; KILP, G. R., "The Influence of Fuel Microstructure on In-Pile Densification.” Nuclear Technology. Vol. 26 - No. 4, 1975. Pag. 486-495.

EL-WAKIL, M. M., "Nuclear Heat Transport." New York. International Textbook Company, 1971. $502 \mathrm{p}$.

FROST, B. R. T., “Nuclear Fuel Elements.” Oxford. Pergamon Press, 1982. 275p.

GEELHOOD, K. J.; LUSCHER, W. G.; BEYER, C. E., "FRAPCON 3.4: A Computer Code for the Calculation of Steady-State Thermal-Mechanical Behaviour of Oxide Fuel Rods for High Burnup.” NUREG/CR-7022, Vol. 1. PNNL-19418, 2011. 134 p. 
GEELHOOD, K. J.; LUSCHER, W.G.; BEYER, C.E.; CUTA, J.M., "FRAPTRAN 1.4: A Computer Code for the Transient Analysis of Oxide Fuel Rods". NUREG/CR-7023, Vol. 1. PNNL-19400, 2011. 165p.

GRANDJEAN, C.; HACHE, G., “A State-of-Art Review of Past Programmes Devoted to Fuel Behaviour Under Loss-of-Coolant Conditions. Part 3. Cladding Oxidation. Resistance to Quench and Post-Quench loads. DPAM/SEMCA 2008-093, 2008. 239p.

HANNERZ, K.; VESTERLUND, G., “Zircaloy Cladding Mechanical Properties.” Nuclear Engineering and Design. Vol. 33. 1975. Pg. 205-218.

IAEA - INTERNATIONAL ATOMIC ENERGY AGENCY, "Fuel Modelling at Extended Burnup. Report of the Coordinated Research Programme on Fuel Modelling at Extended Burnup - FUMEX (1993 - 1996)". IAEA-TECDOC-998 (1998).

IAEA - INTERNATIONAL ATOMIC ENERGY AGENCY, "Fuel Modelling at Extended Burnup (FUMEX-II). Report of the Coordinated Research Project (2002 - 2007)". IAEATECDOC-1687.

IAEA - INTERNATIONAL ATOMIC ENERGY AGENCY, "Improvement of Computers Codes Used for Fuel Behaviour Simulation (FUMEX-III) - Report of a Coordinated Research Project 2008-2012”, 2012. IAEA-TECDOC-1697.

JERNKVIST, L. O.; MASSIH, A. "Evaluation of the FRAPCON-3 Computer Code." SKI Report 02:29. ISSN 1104-1374, 2002. 49 p.

JERNKVIST, L. O.; MASSIH, A. "Models for Fuel Rod Behaviour at High Burnup.” SKI Report 2005:41. ISSN 1104-1374, 2004. 74 p.

JERNKVIST, L. O.; MASSIH, A.; BETOU, J. I., "Evaluation of Fission Product Gas Release and the Impacto f Fuel Microstructure at High Burnup." Halden Programme Group Meeting. 2002. 20 p. 
KIDO, T.; KANASUGI, K.; SUGANO, M.; KOMATSU, K., "PWR Zircaloy Cladding Corrosion Behavior: Quantitative Analysis.” Journal of Nuclear Materials, Vol. 248. 1997. Pg. 281-287.

KINOSHITA, M. et al., "High Burnup Rim Project (III): Properties of Rim Structured Fuel.” Proceedings of International Meeting on Light Water Reactor Fuel Performance, Orlando, Florida. 2004.

LASSMAN, K.; O'CARROL, C.; VANDERLAAR, J.; WALKER, C. T., "The Radial Distribution of Plutonium in High Burnup $\mathrm{UO}_{2}$ Fuels", Journal of Nuclear Materials, Vol. 28, pag. 223-231.

LASSMAN, K.; WALKER, C. T.; VANDERLAAR, J.; LINDSTROM, F., "Modeling the high Burnup $\mathrm{UO}_{2}$ Structure in LWR Fuel”, Journal of Nuclear Materials, Vol. 226, 1995. Pag. 1-8.

LEFEBVRE, F.; LEMAIGNAN, C., "Irradiation Effects on Corrosion of Zirconium Alloy Caddings.” Journal of Nuclear Materials. Vol. 248. 1997. Pg. 268-274.

LIMBACK, M. et al., "Corrosion and Hydriding Performance of Zircaloy-2 and Zircaloy-4 Cladding Materials in PWRs.” Proc. ANS Topical Meeting on Ligth Water Reactor Fuel Performance, USA. 1994. Pg. 286-295.

LUSCHER, W.G.; GEELHOOD, K.J., "Material Property Correlations: Comparisons Between FRAPCON 3.4, FRAPTRAN 1.4 e MATPRO." NUREG/CR-7024. PNNL19417, 2011. 137 p.

MAKI, J. T.; MEYER, J. E., "LWR Fuel Performance Analysis - Fuel Cracking and Relocation”. Massachusetts Institute of Technology, Cambridge. MIT-EL 78-038. 1978. $122 \mathrm{p}$.

MANNGARD, T., "Evaluation of the FRAPTRAN-1.3 Computer Code." Swedish Nuclear Power Inspectorate. SKI Report 2007:15. 2001. 63 p. 
MATZKE, H.; SPINO, J., "Formation of the Rim Structure in High Burnup Fuel.” Journal of Nuclear Materials, Vol. 248. 1997. Pag. 170-179.

OGUMA, M., "Cracking and Relocation Behavior of Nuclear Fuel Pellets During Rise to Power”. Nuclear Engineering and Design, Vol. 76, Issue 1. 1983. Pg. 35-45.

OHIRA , K.; ITAGAKI, N., "Thermal Conductivity Measurements of High Burnup UO2 Pellets and Benchmark Calculation of Fuel Center Temperature." Proceedings of the ANS International Topical Meeting on LWR Fuel Performance, Portland, 1997. Pag. 541-549.

OLANDER, D. R., "Fundamental Aspects of Nuclear Reactor Fuel Elements." Virginia (EUA). Technical Information Center - Energy Research and Development Administration, 1976.613p.

OZISIK, M. N., "Finite Difference Methods in Heat Transfer", Boca-Raton - CRC Press, USA, (1994). 432p.

PARRY, G. W., "Zirconium in the Nuclear Industry.” American Society for Testing and Materials. 1984. 849p.

PICKMAN, D. O., "Properties of Zircaloy Cladding." Nuclear Engineering and Design. Vol. 21. 1972. Pg. 212-236.

ROBERTSON, J. A. L., "Irradiation Effects in Nuclear Fuels." New York. Gordon and Breach, Science Publishers. 1969. 307p.

RONCHI, C.; SHEINDLIN, M.; STAICU, D.; KINOSHITA, M., "Effect of Burn-up on the Thermal Conductivity of Uranium Dioxide Up to $100.000 \mathrm{MWdT}^{-1}$ ”. Journal of Nuclear Materials Vol. 327. 2004. Pg. 58-76.

ROY, P. R.; SAH, D. N., “Irradiation Behavior of Nuclear Fuels.” Pramãna. Vol.24, Nos. 1 \& 2, January \& February 1985. Pg. 397-421. 
RUDLING, P. et al., "High Burnup Fuel Issues". Nuclear Engineering and Technology, Vol. 40, No. 1. 2008. Pg. 1-8.

SMALL, G. J., "Densification of Uranium Dioxide at Low Burn-up". Journal of Nuclear Materials, Vol. 148, Issue 3. 1987. Pg. 302-315.

TERREMOTO, L. A. A., "Danos de Irradiação em Materiais Cristalinos". Instituto de Pesquisas Energéticas e Nucleares - IPEN, São Paulo. 2012. 39p.

WALKER, C. T. et al., "On the Thermal Conductivity of $\mathrm{UO}_{2}$ Nuclear Fuel at a High Burnup of Around 100 MWd/kgHM”. Journal of Nuclear Materials, Vol. 350. 2006. Pg. 19-39. 


\section{APÊNDICE 1}

- Arquivo de Dados de Entrada FRAPCON-3.4a - Caso IFPE/US-PWR-16x16-LTA.

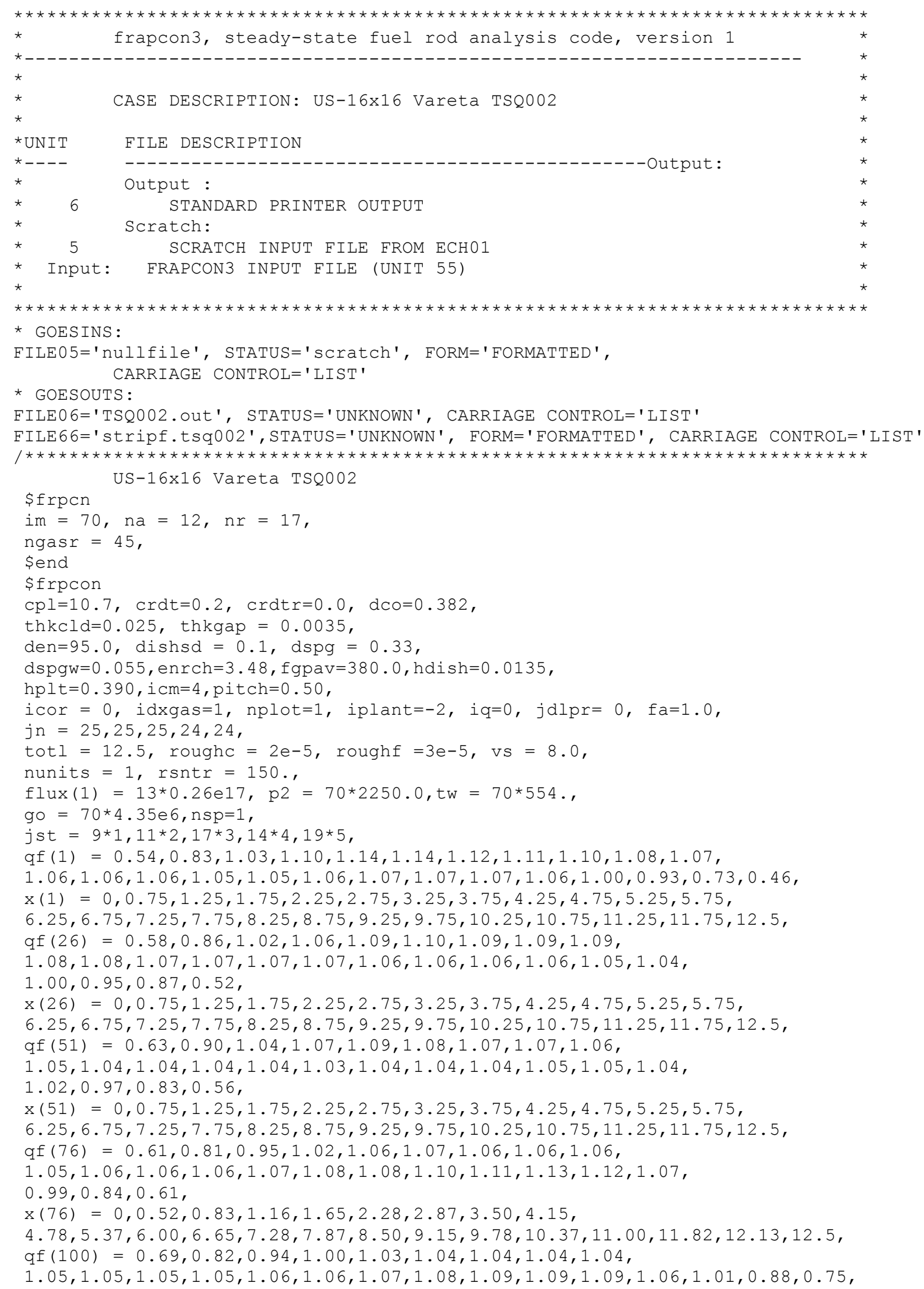


$x(100)=0,0.52,0.83,1.16,1.65,2.28,2.87,3.50,4.15$, $4.78,5.37,6.00,6.65,7.28,7.87,8.50,9.15,9.78,10.37,11.00,11.82,12.13,12.5$, ProblemTime $=9.8,68.7,91.5,139.6,187.7,209.8,236.6,263.0,292.3$, $307.2,321.0,334.7,362.2,389.7,417.0,444.4,471.7,499.0,526.2,548.7$, $553.3,561.3,570.7,586.2,605.9,621.4,639.0,668.9,696.3,726.5$,

$756.4,786.2,813.9,843.2,886.4,905.4,919.8$,

$926.6,933.5,947.2,974.9,1002,1030,1057,1085,1112,1140,1168,1196,1223,1243$,

$1249,1256,1270,1296,1322,1350,1376,1403,1430,1456,1483,1510,1537$,

$1563,1590,1617,1644,1670,1697$,

qmpy $=3.28,4.34,4.31,4.3,4.32,4.29,4.32,4.35,2.88$,

$6.95,6.95,6.91,6.84,6.8,6.76,6.73,6.7,6.68,6.65,6.62$,

$5.95,5.95,5.76,5.78,5.86,5.87,5.81,5.79,5.77,5.75$,

$5.72,5.68,5.68,5.62,4.8,5.05,5.62$,

$4.37,4.41,4.4,4.37,4.38,4.39,4.4,4.42,4.43,4.4,4.4,4.4,4.4,4.4$,

$2.75,2.97,2.82,2.88,2.92,3.01,3.09,3.14,3.21,3.27$,

$3.33,3.39,3.46,3.52,3.59,3.66,3.69,3.82,3.89$,

slim $=.05$,

\$end

\section{- Resumo dos Dados de Saída FRAPCON-3.4a - Caso IFPE/US-PWR-16x16-LTA.}

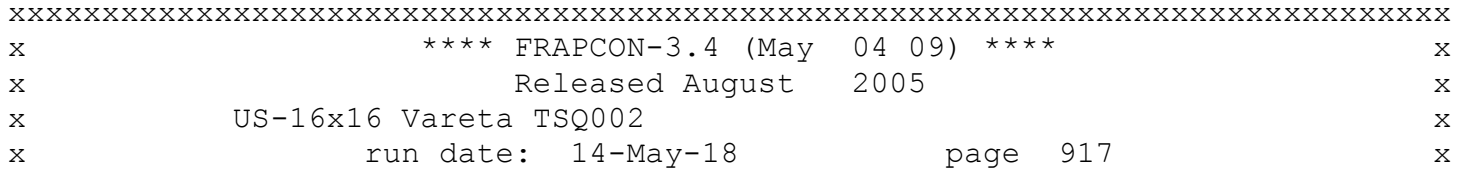

XXXXXXXXXXXXXXXXXXXXXXXXXXXXXXXXXXXXXXXXXXXXXXXXXXXXXXXXXXXXXXXXXXXXXXXXXXXXX

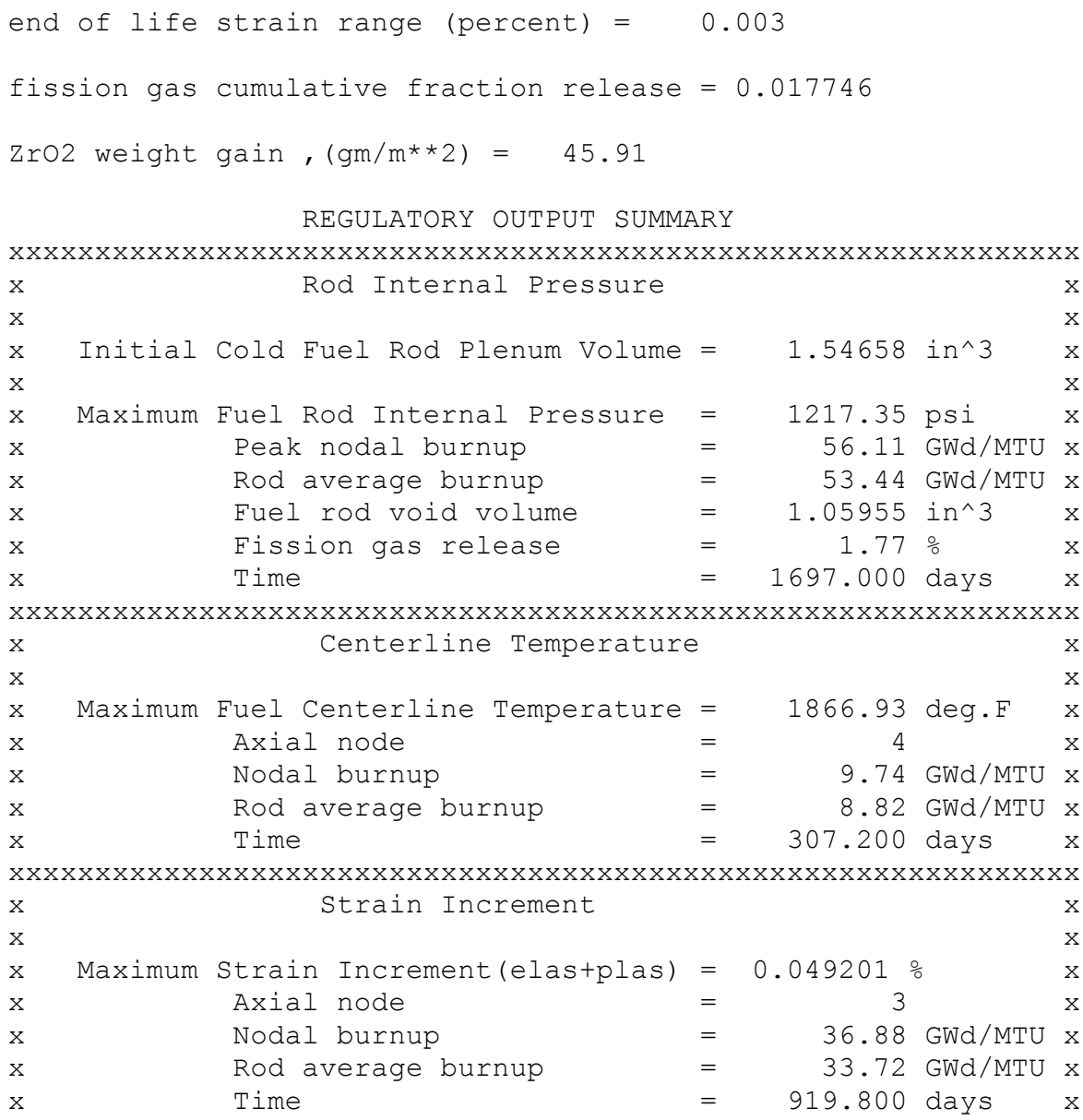

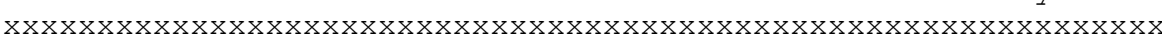




\section{APÊNDICE 2}

- Arquivo de Dados de Entrada FRAPCON-3.4a - Caso IFPE/RISOEIII - NEA-1493/17.

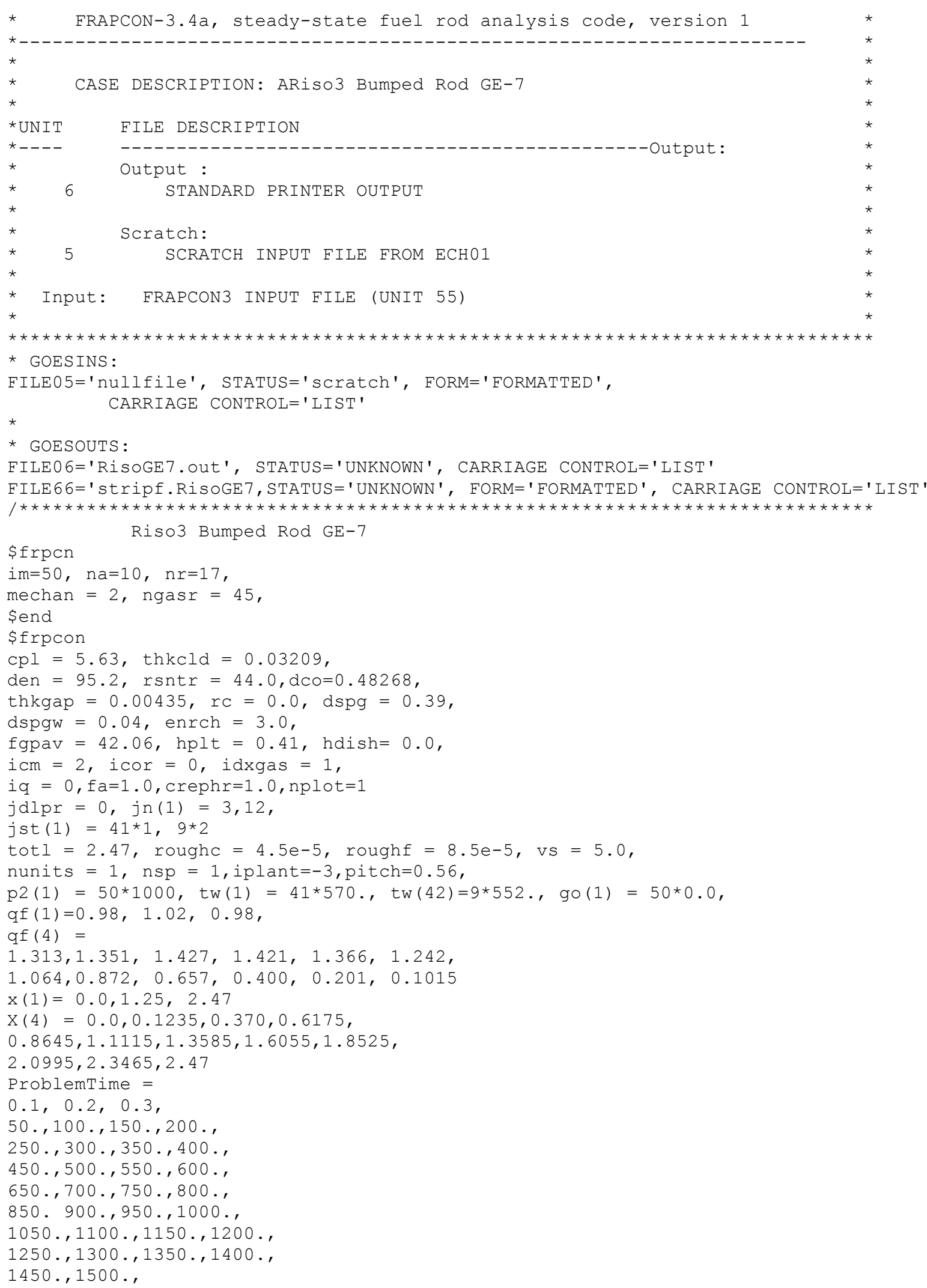


$1550,1600,1650 ., 1700 .$,

$1750 ., 1800 ., 1850 ., 1900 .$,

$1900.2,1900.4,1900.6,1900.85$,

$1900.87,1900.89,1900.91$,

$1900.93,1901.08$

qmpy $=$

$2.0,4.0,6.0$,

$8.5,7.5,7.5,6.5$,

$6.0,6.0,6.0,6.0$,

$5.0,4.0,6.0,6.0$,

$6.5,6.5,5.25,5.25$

$5.25,4.5,3.5,2.5$,

$2.5,5.0,5.0,5.0$,

$4 * 5.0$,

$7 * 4.0,4.5$,

$5.0,4.0$,

$2.0,4.0,6.0,7.0$,

$8.0,9.0,10.0$,

$10.8,10.8$

\$end

- Resumo dos Dados de Saída FRAPCON-3.4a - Caso IFPE/RISOEIII - NEA-1493/17.

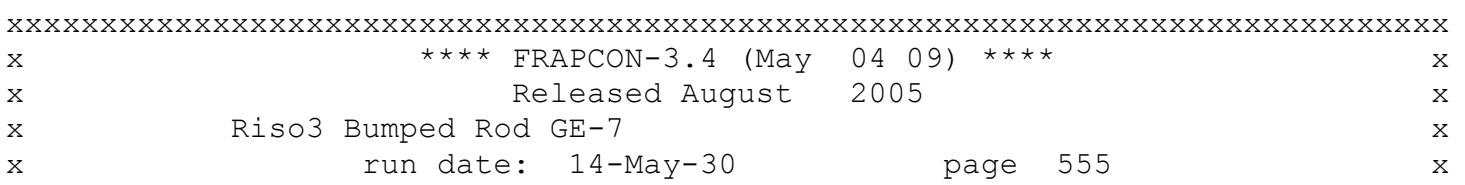

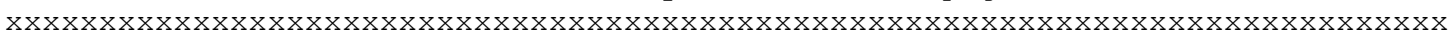

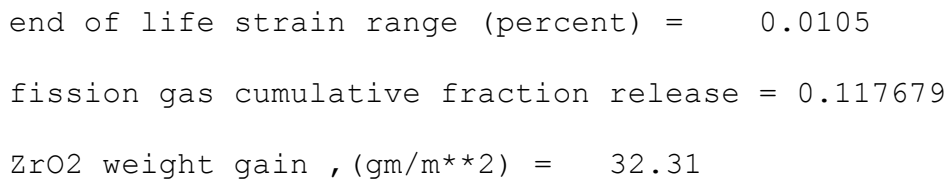

REGULATORY OUTPUT SUMMARY

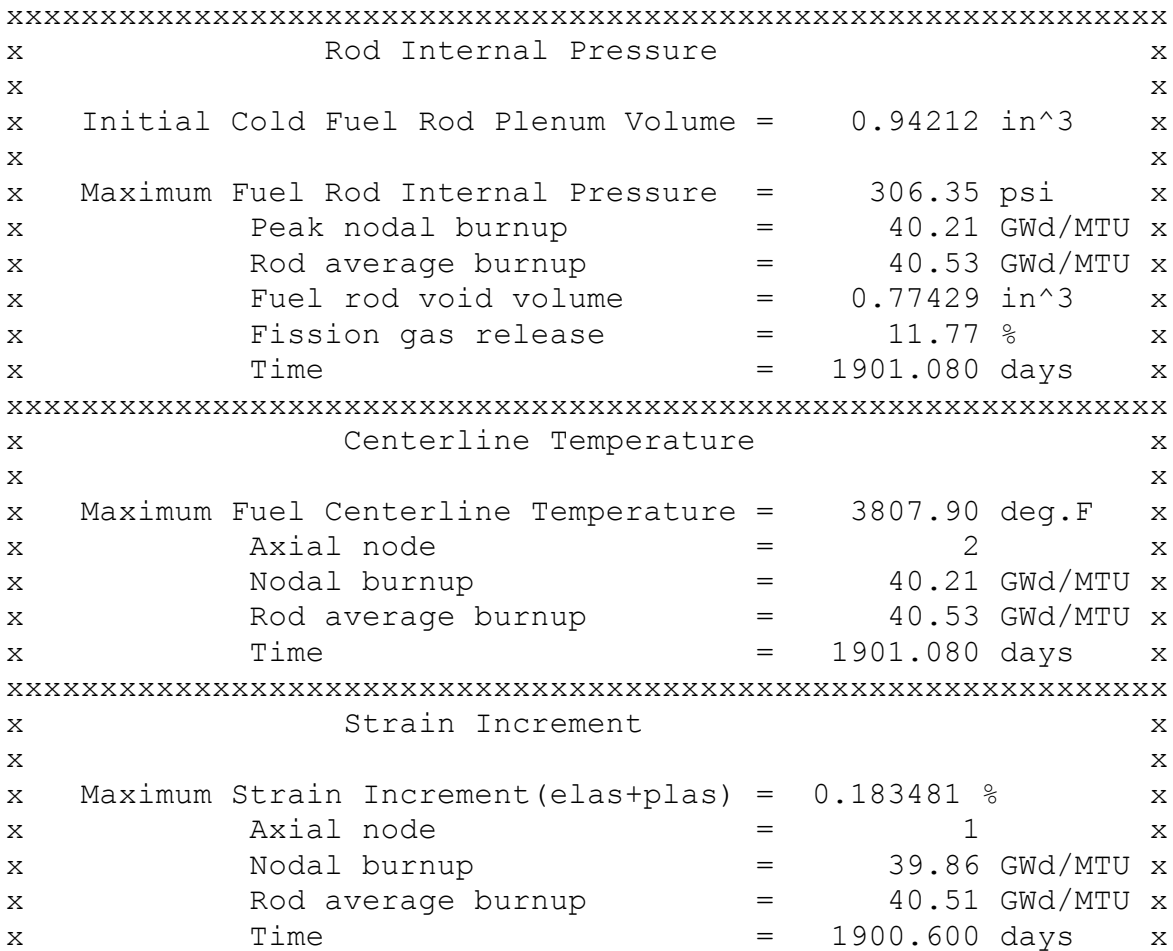

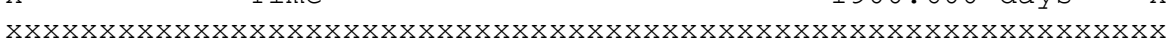




\section{APÊNDICE 3}

- Arquivo de Dados de Entrada FRAPCON-3.4a - Caso IFPE/NSRR-FK1 NEA-1724/01 (Irradiação inicial da vareta (base) - saída será utilizada como entrada para o FRAPTRAN).

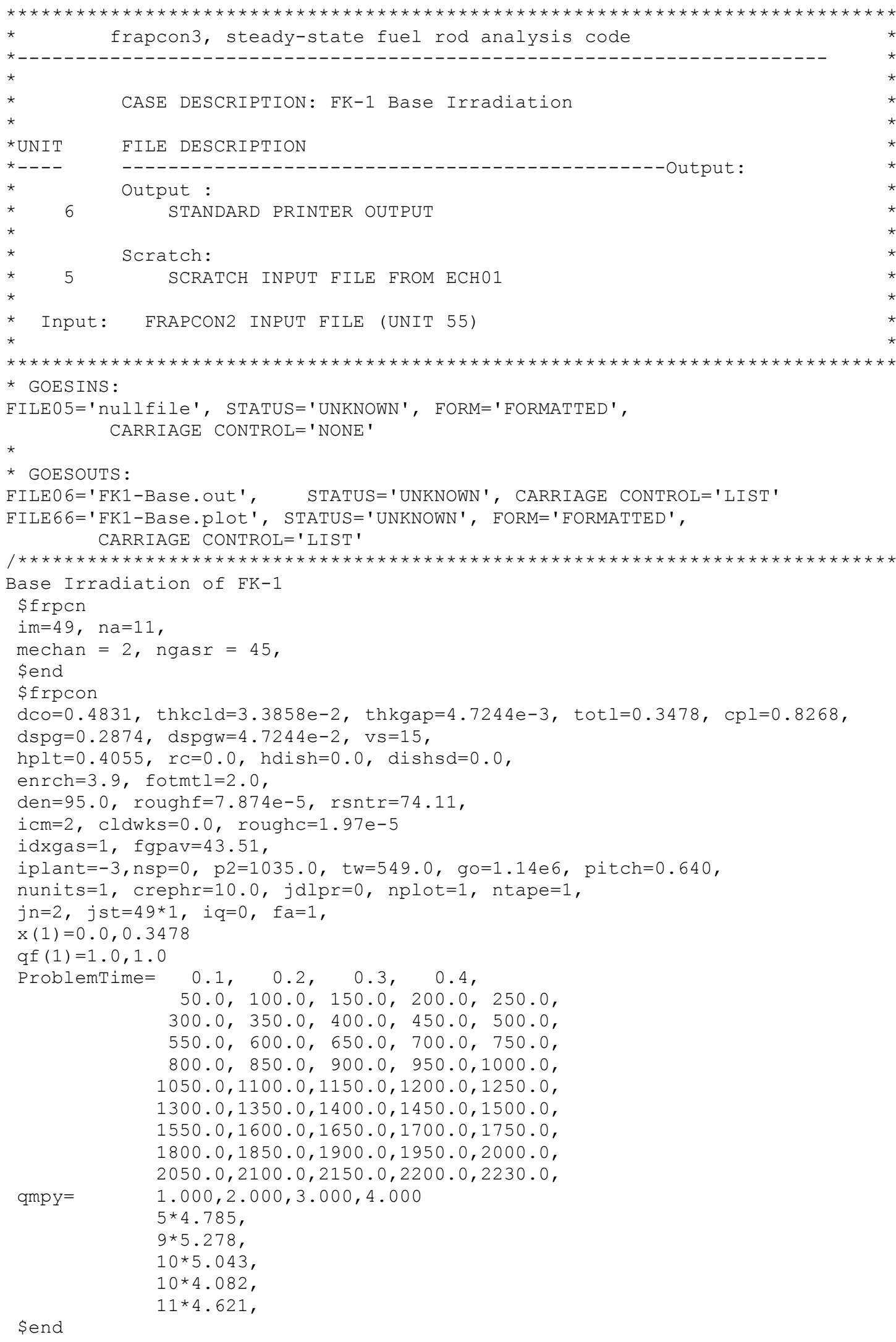

Send 
- Resumo dos Dados de Saída FRAPCON-3.4a - IFPE/NSRR-FK1 NEA-1724/01.

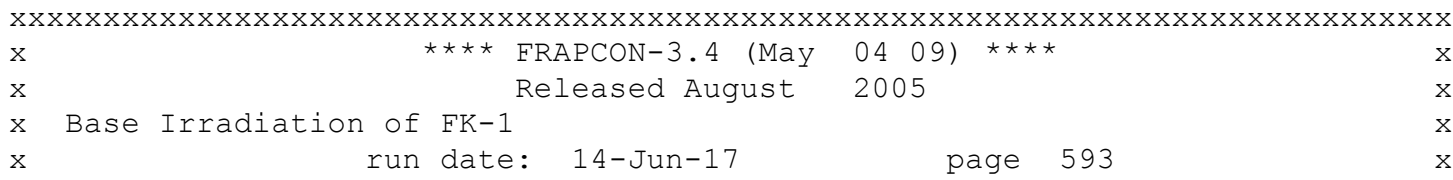
XXXXXXXXXXXXXXXXXXXXXXXXXXXXXXXXXXXXXXXXXXXXXXXXXXXXXXXXXXXXXXXXXXXXXXXXXXXXX

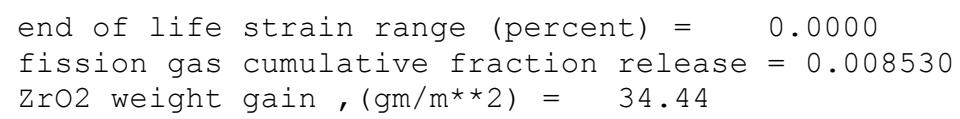

\section{- Arquivo de Dados de Entrada FRAPTRAN-1.4 - Caso IFPE/NSRR-FK1 NEA-1724/01.}

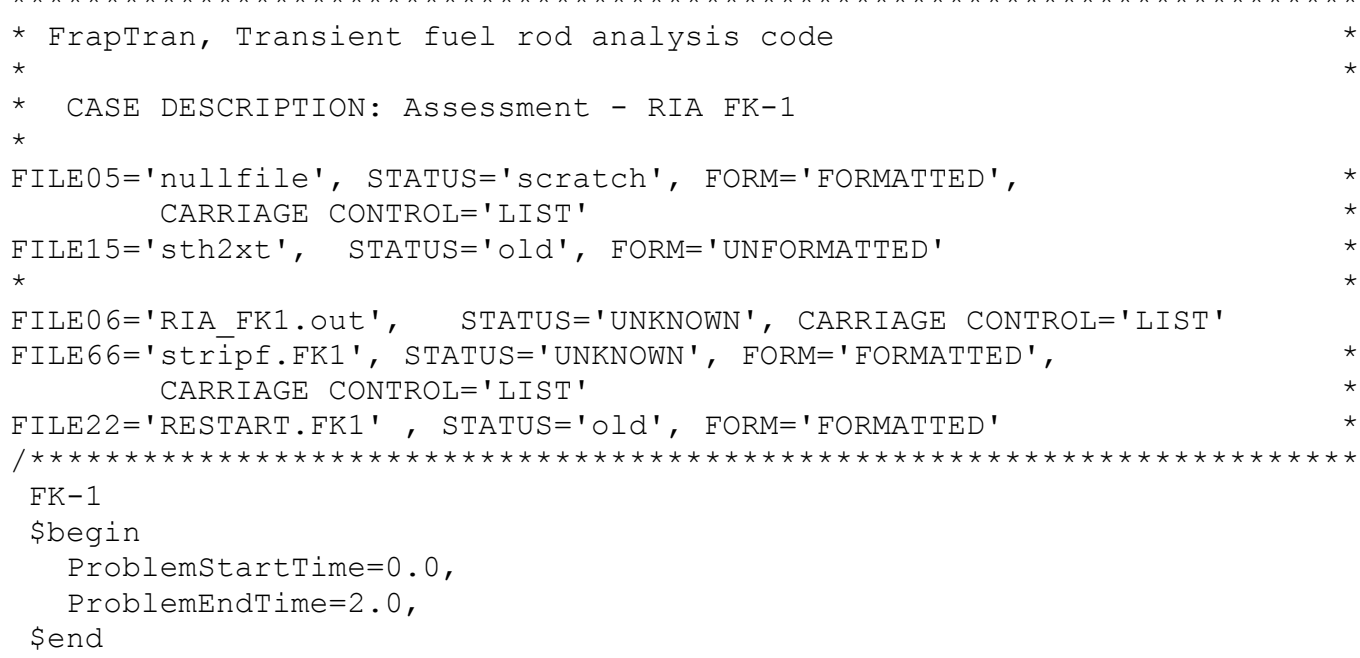




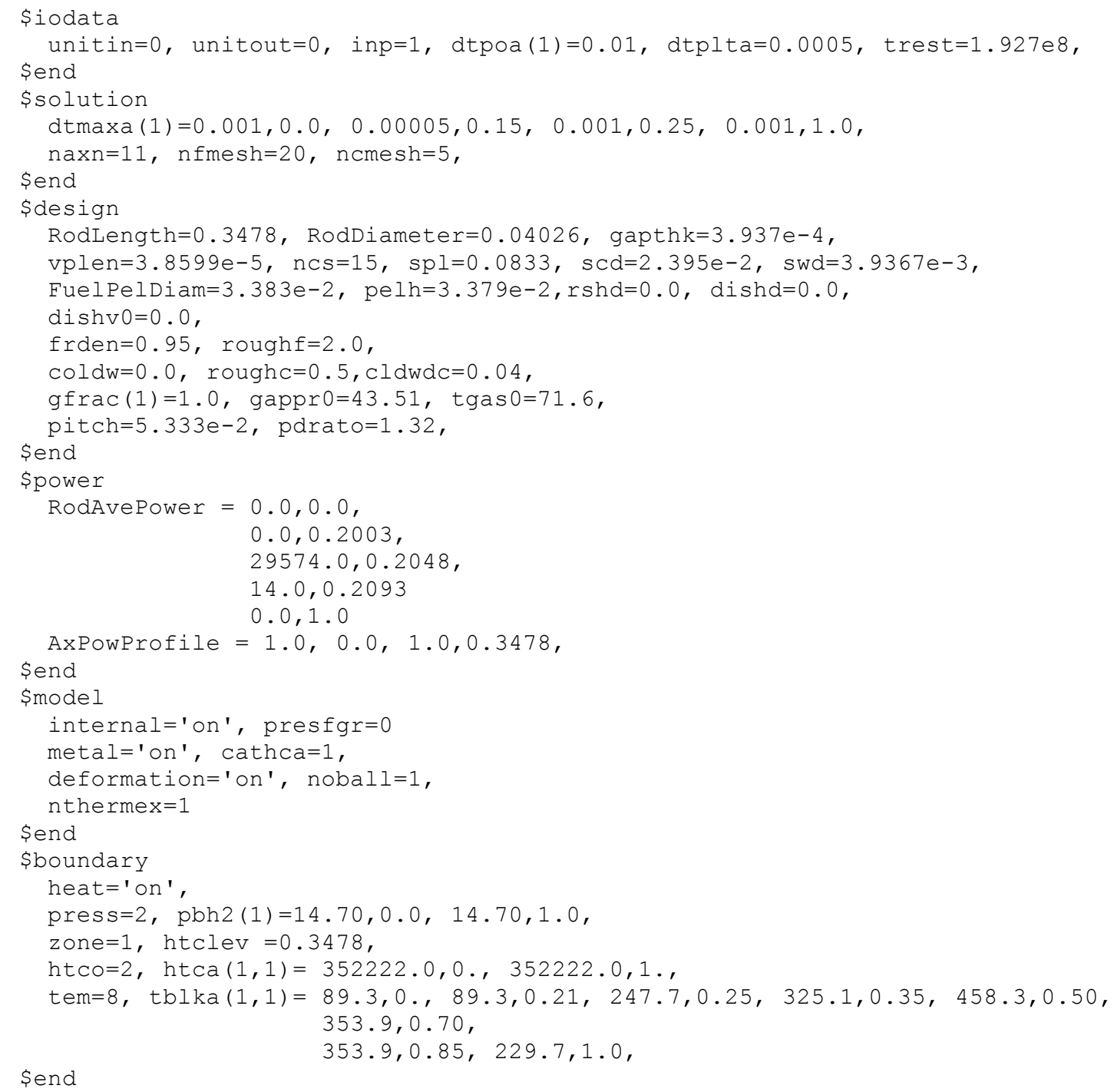

